CLÁUDIA DE OLIVEIRA GOMES

ESTUDO ANALÍTICO E OPERACIONAL DO MODELO TECNOLÓGICO DE UM SISTEMA DE SEGURANÇA PÚBLICA PORTUÁRIA ADEQUADO AO ISPS CODE IMPLEMENTADO NO PORTO DE SANTOS. 
CLÁUDIA DE OLIVEIRA GOMES

\section{ESTUDO ANALÍTICO E OPERACIONAL DO MODELO TECNOLÓGICO DE UM SISTEMA DE SEGURANÇA PÚBLICA PORTUÁRIA ADEQUADO AO ISPS CODE IMPLEMENTADO NO PORTO DE SANTOS.}

Dissertação apresentada à Escola Politécnica da Universidade de São Paulo, para obtenção do grau de Mestre em Engenharia.

Área de Concentração:

Engenharia de Energia e Automação Elétricas

Orientador:

Prof. Dr. Eduardo Mario Dias 
Este exemplar foi revisado e alterado em relação à versão original, sob responsabilidade única do autor e com anuência de seu orientador.

São Paulo, de janeiro de 2008.

Assinatura do autor

Assinatura do orientador

FICHA CATALOGRÁFICA

Gomes, Claudia de Oliveira

Estudo analítico e operacional do modelo tecnológico de um sistema de segurança pública portuária adequado ao ISPS CODE implementado no Porto de Santos / C.O. Gomes. -ed.rev.- São Paulo, 2008.

$161 \mathrm{p}$.

Dissertação (Mestrado) - Escola Politécnica da Universidade de São Paulo. Departamento de Engenharia de Energia e Automação Elétricas.

1.Código ISPS 2.Sistema de segurança 3.Plano de Segurança Pública Portuária I.Universidade de São Paulo. Escola Politécnica. Departamento de Engenharia de Energia e Automação Elétricas II. $t$. 


\section{AGRADECIMENTOS}

Ao meu marido Maurício e filhos Leandro e Gustavo, a minha madrinha Sueli, pelo apoio, incentivo e motivação para elaboração deste trabalho.

Ao amigo e Prof. Dr. Eduardo Mário Dias pela orientação para o desenvolvimento desta dissertação de mestrado e pela confiança em minha capacidade profissional.

Aos colegas Caio Fontana, Fábio Pires pela contribuição com propostas para este modelo.

Aos engenheiros responsáveis pela implantação do Código ISPS no porto de Santos, João Fernando Cavalcanti Gomes da Silva e Álvaro Luiz Dias de Oliveira por disponibilizarem e prestarem as informações que auxiliaram em grande parte deste trabalho.

Aos engenheiros Pedro Mauro Lopes, Superintendente de Tráfego e Atracação, Randolfo de Melo Alonso, gerente de Atracação e Serviços e Márcia Rubino Ferreira Pereira pela atenção e cooperação durante estes três anos de estudos. 
O que prevemos raramente ocorre; o que menos esperamos geralmente acontece.

(Benjamin Disraeli) 


\section{RESUMO}

GOMES, C. O. Estudo Analítico e Operacional do Modelo Tecnológico do Sistema de Segurança Pública Portuária Adequado ao ISPS Code Implementado no Porto de Santos. 2008. 161 f. Dissertação (mestrado). Escola Politécnica. Universidade de São Paulo. São Paulo. 2008.

O complexo porto/navio constitui-se em uma grande e intrincada rede de relações que abarca, desde manutenção/aprimoramento de instalações físicas até o uso dos mais sofisticados meios de gerenciamento e controle de pessoas e operações. Nesse contexto, as questões de segurança colocam-se como de fundamental importância para os sistemas portuários de vários países. Se isto já era um fato, essas preocupações assumiram maior força depois dos ataques terroristas em 11 de setembro, nos Estados Unidos. A preocupação com a segurança portuária encontrase explicitada em determinações da Organização Marítima Internacional (IMO). Dentre as medidas adotadas o Código Internacional para Proteção de Navios e Instalações Portuárias (Código ISPS ou ISPS Code) assume particular importância nas definições de procedimentos de segurança nos complexos portuários. Vem sendo adotado em cerca de 45 mil embarcações, 15 mil portos e instalações portuárias de 162 países signatários, entre os quais o Brasil.O prazo limite para sua implantação nos países signatários foi $1^{\circ}$ de julho de 2004. Para implementar medidas de proteção do ISPS Code, o governo brasileiro aprimorou o Plano de Segurança Pública Portuária Brasileira (PSPP), com o objetivo de adotar medidas para intensificar o controle de cargas, veículos e pessoas na "interface cais-navio", como medida preventiva de proteção em função do aumento do risco de atentados terroristas. Além disso, visa melhorar a operação portuária e tornar os portos mais competitivos e seguros para o comércio exterior, setor em que representam peça fundamental na logística das operações. Nesse sentido, as operações portuárias devem ser ágeis, seguras e com fluxo contínuo de informações para garantir o desempenho e competitividade do comércio internacional do País. O transporte marítimo concentra mais de $90 \%$ do volume da movimentação de cargas internacionais do País e os portos acumularam, nos últimos anos, grandes investimentos, efetuados principalmente pela iniciativa privada. A junção das determinações do ISPS Code e do Plano de Segurança possibilitou a construção de um modelo de segurança para que os portos não percam cargas por falta de organização, e para garantir que os pontos críticos de segurança 
não representem obstáculos para o comércio internacional. Para melhor compreensão esta dissertação, detalha analítica e operacionalmente o modelo tecnológico adotado no porto de Santos para atender o sistema de segurança, em função de ser ferramenta fundamental para a organização de setores portuários. O trabalho, inicialmente, apresenta um breve histórico de medidas dirigidas ao setor portuário brasileiro após a extinção da Portobrás, destacando as relações entre normas de segurança internacional e normas brasileiras, definidas na implantação de um plano nacional de segurança de portos. A seguir, dada a complexidade do sistema portuário, são apresentadas as várias entidades que a ele se relacionam. Tendo como foco a segurança dos portos, o trabalho apresenta as várias normas que regulam a questão e analisa as tecnologias implementadas para integração dos vários subsistemas no porto de Santos, esse modelo tecnológico hoje é tido como referencial aos demais portos brasileiros, não devendo nada aos portos estrangeiros.

Palavra Chave: Código ISPS. Sistema de Segurança. Plano de Segurança Pública Portuária. 


\section{ABSTRACT}

GOMES, C. O. Analytical and Operational Study of the Technological Pattern of the Port Public Security System Adequate to ISPS Code Applied in Santos Port. 2008. 161 f. Dissertação (mestrado). Escola Politécnica. Universidade de São Paulo. São Paulo. 2008.

The complex port-vessel is set up in a really intricate relationship that involves not only maintenance and improvement of the premises, but also the most sophisticated ways of management and control of people and operations. In this context security is the fundamental factor to port systems in many countries. It became even more important after the terrorist attacks on September 11th in the USA. Determinations of the International Maritime Organization (IMO) explicitly showed that concern about port security and the security procedures of the ISPS Code (an international code for the vessel and port protection) were considered particularly important to all ports. About 45 thousands vessels and 15 thousands ports and port equipment of 162 signatory countries, Brazil included, have already been following these code procedures. The deadline for the adoption of this code by these countries was July 1st, 2004. In order to enhance the security elements included in the ISPS Code, the Brazilian government created the PSPP (Plano de Segurança Pública Portuária Brasileira), to implement new rules to intensify cargo, vehicles and people control in the dock-ship area, and also as a protective precaution due to the increasing risk of terrorist attacks. Moreover, all these rules will perfect port operations and make our ports more competitive and secure for foreign trade where the same rules play an important role in logistic operations. That is why port operations must be agile, secure and they must manipulate a fast information system to make the country foreign trade performance trustworthy and competitive. The maritime transportation comprises more than $90 \%$ of the amount of the international cargo movement in our country and huge investments have been made in the ports, mostly by private enterprises.

The introduction of the ISPS Code and PSPP determination enabled the creation of a system of security which eliminates the risk of cargoes being lost in the port through the lack of organization and guaranteeing an acceptable safety level in all ports.

To illustrate and expand on these issues, this essay will show analytical and operational details of the technological pattern of the port of Santos where the new security system is the fundamental tool to the port organization. At first this essay will 
present a brief summary of rules applicable to Brazilian ports following the elimination of Portobrás. It will point out the relationship between Brazilian and international security rules when they are used in the national level of security of ports. Secondly, due to the intricate port system, many related entities will be introduced. The essay will focus on the security of ports and it will show many rules that control them. It will provide an analysis of all the technologies applied to integrate the inner systems in the port of Santos. This technological pattern is currently the reference standard for other Brazilian ports and meets or exceeds those found in foreign ports.

Keywords: ISPS Code. Security System. Plan of the Public Port Security. 


\section{LISTA DE ILUSTRAÇÕES}

Figura 1: Organograma da Secretaria Especial de Portos .............................................21

Figura 2: Composição Conselho da IMO ................................................................... 33

Figura 3: Distribuição de AIS em pontos de terra......................................................... 41

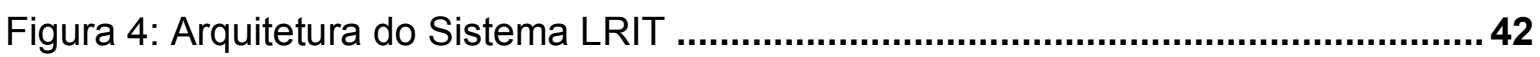

Figura 5: Fluxo de comunicação dos Gates. .............................................................. 57

Figura 6: Sistema wireless para rádio de comunicação de dados, vídeos e VolP.........59

Figura 7: Fluxograma do Cadastramento de Responsável ............................................61

Figura 8: Fluxograma do Cadastramento de Usuários.................................................62

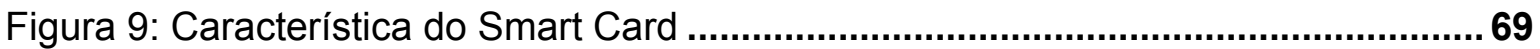

Figura 10: Crachá de pessoas com acesso contínuo (prestadores de serviço, TPA,

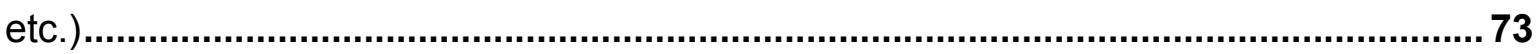

Figura 11: Crachá de veículos de prestadores de serviços..............................................76

Figura 12: Crachá de veículo de visitantes e transportadores .......................................77

Figura 13: Código de hierarquia dos locais de acesso..................................................77

Figura 14: Transações eletrônicas...................................................................................79

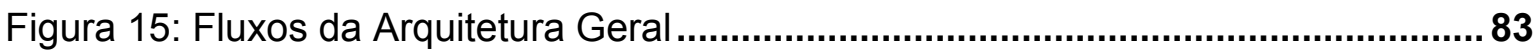

Figura 16: Imagem da tela do sistema de vídeo SmartSight..........................................86

Figura 17: Imagem do gestor de eventos do OPC cliente de monitoração......................87

Figura 18: Tipos de Ativos ..................................................................................88 


\section{LISTA DE TABELAS}

Tabela 1.1: Modais de Transportes das Exportações Brasileiras - 2006 ..................... 18

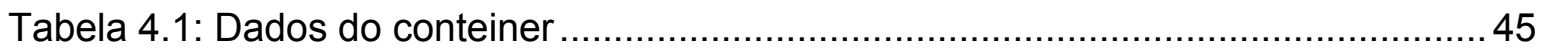

Tabela 4.2: Tabela de movimentação anual de contêineres em TEUS. ......................46

Tabela 4.3: Tabela de movimentação de contêineres no porto de Santos. ..................47

Tabela 4.4: Portos com Iniciativa de Segurança do Conteiner (SCl) ..........................49

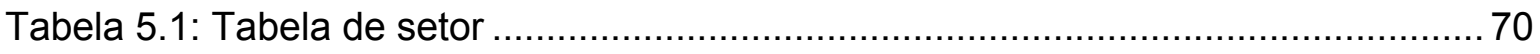

Tabela 5.2: Tabela dos registros de usuários .................................................... 71

Tabela 5.3: Tabela dos tipos de cartão............................................................... 71

Tabela 5.4: Tabela dos tipos de usuário .................................................................. 72

Tabela 5.5: Tabela dos dados do cartão de pessoas ................................................ 73

Tabela 5.6: Tabela dos dados do veículo ................................................................. 74

Tabela 5.7: Tabela dos tipos de veículos .......................................................... 74

Tabela 5.8: Tabela dos dados do cartão de veículo ............................................... 76 


\section{LISTA DE SIGLAS E ABREVIATURAS}

\begin{tabular}{|c|c|}
\hline ABRATEC & Associação Brasileira dos Terminais de Contêineres de Uso Público \\
\hline ADM & Armas de Destruição Maciça \\
\hline AIS & Automatic Identification System \\
\hline ANTAQ & Agência Nacional de Transportes Aquaviários \\
\hline ANVISA & Agência Nacional de Vigilância Sanitária \\
\hline BL & Bill of lading \\
\hline CAP & Conselho de Autoridade Portuária \\
\hline CBC & Câmara Brasileira de Contêineres \\
\hline CBP & Customs and Border Protection \\
\hline CCCOM & Centro de Controle e de Comunicação \\
\hline CESPORTOS & $\begin{array}{l}\text { Comissões Estaduais de Segurança Pública nos Portos Terminais e Vias } \\
\text { Navegáveis }\end{array}$ \\
\hline CODESP & Companhia Docas do Estado de São Paulo \\
\hline CFTV & Circuito Fechado de TV \\
\hline CONPORTOS & $\begin{array}{l}\text { Comissão Nacional de Segurança Pública nos Portos, Terminais e Vias } \\
\text { Navegáveis. }\end{array}$ \\
\hline COMCONTRAM & Comando do Controle Naval do Tráfego Marítimo \\
\hline $\mathrm{COV}$ & Central de Operações e Vigilância \\
\hline DC & Declaração de Cumprimento \\
\hline DNIT & Departamento Nacional de Infra-Estrutura dos Transportes \\
\hline $\mathrm{DP}$ & Departamento de Portos \\
\hline DPF & Departamento de Polícia Federal \\
\hline DPRF & Departamento de Polícia Rodoviária Federal \\
\hline EDI & Eletronic Data Interchange \\
\hline ETA & Estimated Time of Arrival \\
\hline ETD & Estimated Time of Departure \\
\hline EUA & Estados Unidos da América \\
\hline IMCO & Intergovernmental Maritime Consultative Organization \\
\hline IMO & International Maritime Organization \\
\hline INFOCRIM & Sistemas de Informações Criminais \\
\hline INFOSEG & Sistema de Informações de Justiça e Segurança Pública \\
\hline ISSC & International Ship Security Certificate \\
\hline LRIT & Long Range Identification and Tracking of Ships \\
\hline NAPV & Normas de Controle de Acesso e circulação de pessoas e veículos \\
\hline NEPOM & Núcleos Especiais de Polícia Marítima \\
\hline NM & Navios Mercantes \\
\hline NORMAM & $\begin{array}{l}\text { Normas da Autoridade Marítima para Tráfego e Permanência de Embarcações em } \\
\text { Águas Jurisdicionais Brasileiras }\end{array}$ \\
\hline MSC & Maritime Safety Committee \\
\hline OGMO & Órgão Gestor de Mão de Obra \\
\hline ONU & Organização das Nações Unidas \\
\hline PIMOP & Programa Integrado de Modernização Portuária \\
\hline PMAF & Polícia Marítima, Aérea e de Fronteiras \\
\hline PNSA & Plano Nacional de Segurança Aduaneira \\
\hline PNSPP & Plano Nacional de Segurança Público Portuário \\
\hline PORTOBRAS & Empresa de Portos do Brasil S.A. \\
\hline SAR & Search and Rescue \\
\hline SED & Supervia Eletrônica de Dados \\
\hline $\mathrm{SCl}$ & Container Security Initiative \\
\hline SENASP & Secretaria Nacional de Segurança Pública \\
\hline SISNC & Sistema Naval de Comando e Controle \\
\hline SISTRAM & Sistema de Informações sobre o Tráfego Marítimo \\
\hline SOLAS & Safety of Life at Sea \\
\hline SSL & Secure Sockets Layer \\
\hline SSPP & Sistema de Segurança Público Portuário \\
\hline STA & Secretaria de Transportes Aquaviários \\
\hline SRF & Secretaria da Receita Federal \\
\hline SVD & Servidor de Vídeo Digital \\
\hline RAP & Prioridade e Requisição de $A$ \\
\hline
\end{tabular}


RPPS

TA

TEU

TPA

VAN

VHF

VOIP

VTMIS

VTS

USP

UTC

WMD
Roteiro para Elaboração e Análise dos Planos de Segurança Pública Portuária Termo de Aptidão

Twenty Feet Equivalent Unit

Trabalhadores Portuários Avulsos

Value Added Network

Very High Frequency

Voice Over IP

Vessel Traffic Management and Information

Vessel Traffic Service

Universiade de São Paulo

Universal Time Coordination

Weapons of Mass Destruction 
1 MEDIDAS IMPLEMENTADAS PARA SETOR PORTUÁRIO BRASILEIRO 16

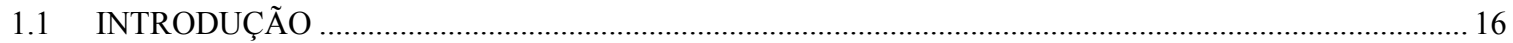

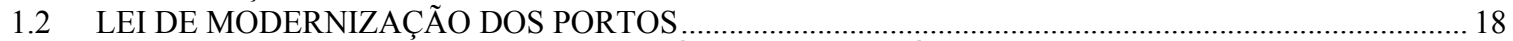

1.3 PLANO NACIONAL DE SEGURANÇA PÚBLICA PORTUÁRIA (PNSPP) ............................................... 21

2 ATORES DO SISTEMA PORTUÁRIO PARA PNSPP ........................................ 24

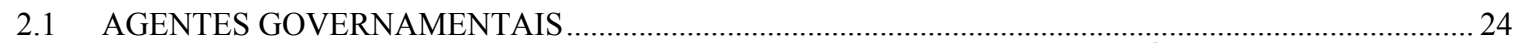

2.1.1 SECRETARIA ESPECIAL DE PORTOS / ADMINISTRAÇÃO PORTUÁRIA ................................ 24

2.1.2 MINISTÉRIO DA FAZENDA / SECRETARIA DA RECEITA FEDERAL ......................................... 24

2.1.3 MINISTÉRIO DA DEFESA / CAPITANIA DOS PORTOS ................................................................ 25

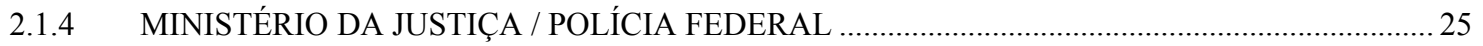

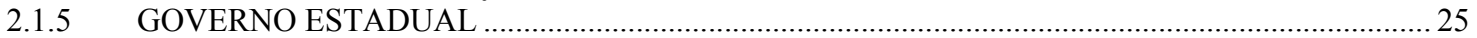

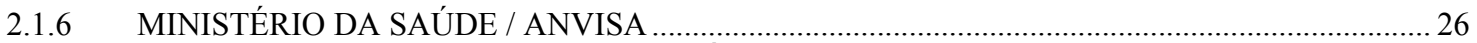

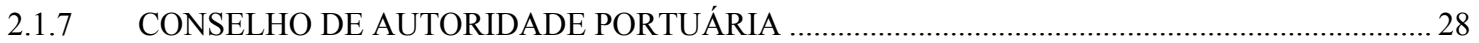

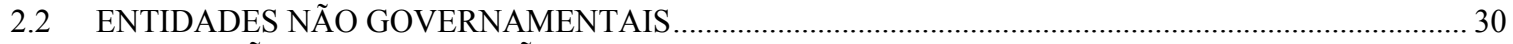

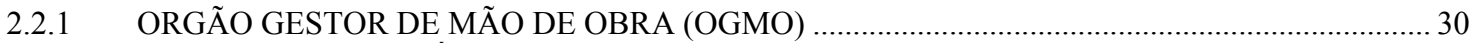

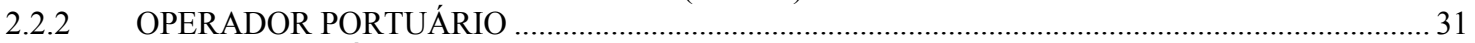

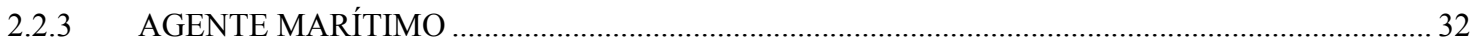

3 CÓDIGO INTERNACIONAL PARA PROTEÇÃO DE NAVIOS E INSTALAÇÕES PORTUÁRIAS (CÓDIGO ISPS) ........................................................................... 33

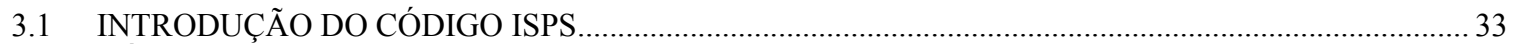

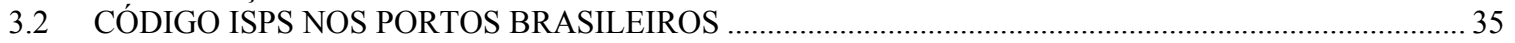

4 OUTROS DESENVOLVIMENTOS NO CONTEXTO DA “SECURITY” ................... 38

4.1 CERTIFICADO INTERNACIONAL DE PROTEÇÃO DO NAVIO (ISSC) .............................................. 38

4.2 SISTEMA AUTOMÁTICO DE IDENTIFICAÇÃO (AIS) …………………………………………...... 39

4.3 SISTEMA DE IDENTIFICAÇÃO E ACOMPANHAMENTO DE NAVIOS A LONGA DISTÂNCIA (LRIT) .......

4.4 SISTEMA DE GERENCIAMENTO DO TRÁFEGO DE NAVIOS (VTMIS)

4.5 EVOLUÇÃO E UTILIZAÇ̃̃O DO CONTEINER ………………………………………………………...... 43

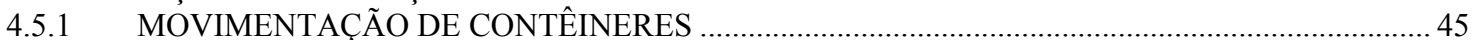

4.5.2 INICIATIVA DE SEGURANÇA DO CONTEINER (SCI) ……………….................................. 47

5 SISTEMA SE SEGURANÇA PÚBLICA PORTUÁRIA NO PORTO DE SANTOS.. 51

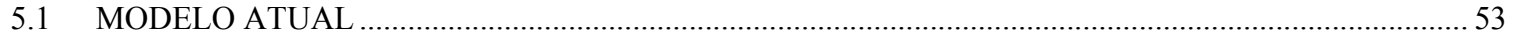

5.2 SISTEMA SUPERVIA ELETRÔNICA DE DADOS (SED) …………………………………………….... 54

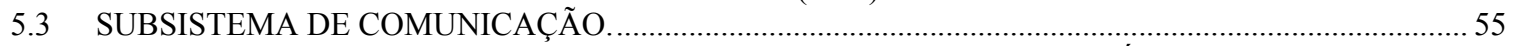

5.4 SUBSISTEMA DE CADASTRAMENTO E CREDENCIAMENTO DE USUÁRIOS ..................................6

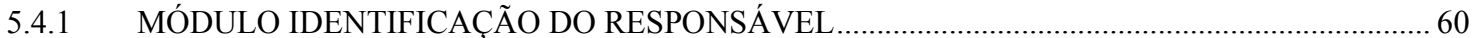

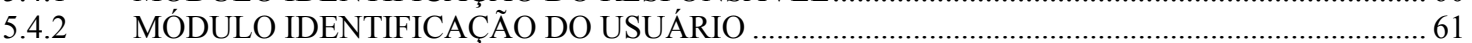

5.5 SUBSISTEMA DE CONTROLE DE ACESSO

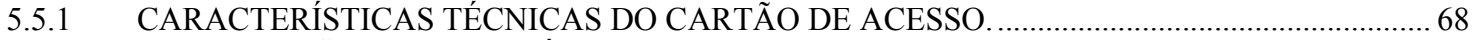

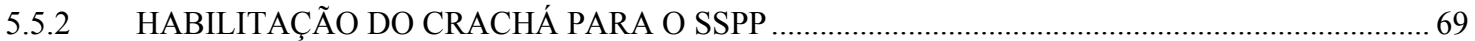

5.5.3 TECNOLOGIA PARA O CONTROLE DE ACESSO ……………………………….............................. 79

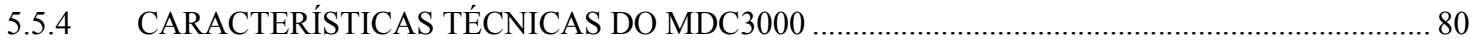

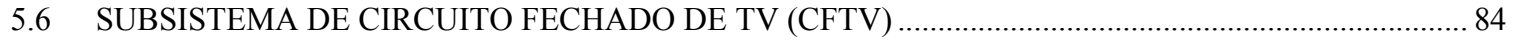

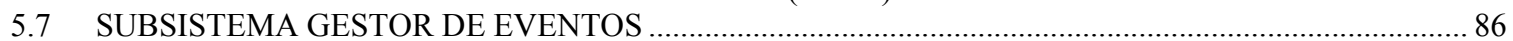

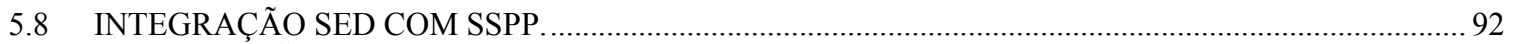

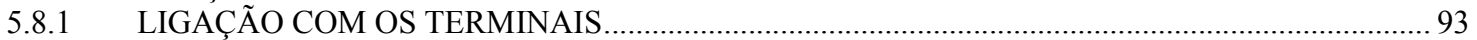

5.9 PLANO NACIONAL DE SEGURANÇA ADUANEIRA (PNSA) ……………………………………...... 94

5.9.1 INTEGRAÇÃO DO SSPP PARA ATENDIMENTO DO PNSA ……………….................................. 96

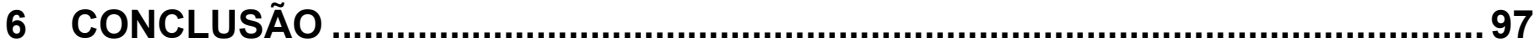

REFERÊNCIAS BIBLIOGRÁFICAS .................................................................. 99 
ANEXO A Plano Nacional de Segurança Pública Portuária

ANEXO B ANVISA - Solicitação de Certificado de Livre Prática

ANEXO C Roteiro para a Elaboração e Análise dos Planos de Segurança Pública Portuária - RPPS

ANEXO D Declaração de Proteção

ANEXO E Distribuição dos Gates no Porto de Santos - Geral

ANEXO F Distribuição dos Gates no Porto de Santos - Lado Alemoa

ANEXO G Distribuição dos Gates no Porto de Santos - Lado Ponta da Praia

ANEXO H Documentos Exigidos para Cadastramento de Responsável e Usuários

ANEXO I Especificações Técnicas para Distribuição das Senhas de Leitura dos Crachás de acesso

ANEXO J Especificações Técnicas dos Arquivos de dados a serem trocados na Supervia Eletrônica de Dados 


\section{MEDIDAS IMPLEMENTADAS PARA SETOR PORTUÁRIO BRASILEIRO}

\subsection{INTRODUÇÃO}

Com a extinção da Empresa de Portos do Brasil S.A. - PORTOBRAS - criada em 1975, iniciaram-se as reformas e a modernização do setor Portuário, ocasião em que este perdeu sua formatação sistêmica e planejamento centralizado, abrindo espaço para a concorrência entre portos, em âmbito nacional. As reformas consolidaram-se com a promulgação e a implementação pelo governo brasileiro da Lei n'. 8.630, de 25 de fevereiro de 1993, denominada de Lei de Modernização dos Portos.

A Lei $n^{\circ} .8 .630$ incentivou a privatização dos serviços portuários, criando áreas arrendadas dentro dos limites do porto organizado. Com ela, surgiu a figura do operador portuário, pessoa jurídica com a função de realizar as operações portuárias, cuja pré-qualificação para o desempenho dessas atividades deve ser obtida junto à Administração do Porto. Essa inovação altera a forma como o sistema da mão-de-obra "avulsa" era gerenciado, na medida em que introduz o contrato

coletivo de trabalho com função deliberativa e cria o Órgão Gestor da Mão-de-Obra (OGMO), com função executiva.

A Lei de Modernização dos Portos atuou no sentido de que o sistema brasileiro de gestão portuária se aproximasse dos modelos de gerenciamento vigentes nos países mais industrializados, nos quais as decisões sobre os assuntos relacionados ao arrendamento de terminais, alteração na execução das tarefas, mudanças nas jornadas de trabalho, dentre outros, tinham sido tomadas a nível local, atendendo o máximo possível das necessidades comerciais da região onde atua.

Devido a permanente falta de segurança nos portos brasileiros, o governo criou a Comissão Nacional de Segurança Pública nos Portos, Terminais e Vias Navegáveis (CONPORTOS) pelo Decreto 1.507 de 30 de maio 1995, alterado pelo Decreto 1.972 de 30 de julho de 1996, tendo por objetivo elaborar e implementar o sistema de prevenção e repressão a atos ilícitos nos portos. 
No âmbito do tráfego internacional as questões de segurança também foram objeto de discussões e foco de criação de normas para o setor portuário. A Conferência Diplomática da Organização Marítima Internacional - IMO, em 12 de Dezembro de 2002, adotou as alterações à Convenção Internacional para a Salvaguarda da Vida Humana no Mar de 1974 (Convenção SOLAS) e um Código Internacional para a Proteção ${ }^{1}$ de Navios e Instalações Portuárias (Código ISPS). Tais instrumentos incluíram disposições obrigatórias na Comunidade Portuária.

O Código ISPS veio em um momento oportuno para o Brasil, que já estava devendo muito no quesito segurança. É preciso notar que, mesmo sem haver registro de atos terroristas no Brasil, os portos brasileiros podem ser utilizados para atingir navios de outros países, com a finalidade de destruí-los ou de atacar os portos dos países nos quais eles atracarão.

Ainda assim, a implantação das medidas relativas ao tipo de segurança previsto no Código ISPS no setor marítimo-portuário não é de fácil concretização. Existem aspectos que dificultam a sua implementação como a falta de meios e equipamentos de controle nos terminais e o número elevado de instalações portuárias.

O Brasil, para implementar medidas de proteção do Código ISPS, melhorar a operação portuária e tornar os portos mais competitivos e seguros para o comércio exterior, buscando superar uma situação de fragilidade no controle e na segurança dos portos, aprimorou o Plano de Segurança Pública Portuária Brasileira ou PSPP.

A composição do PSPP contará com a integração da Autoridade Portuária, com os Terminais e Autoridades Externas como a Polícia Federal, Ministério da Justiça, Ministério dos Transportes, Marinha do Brasil, Receita Federal.

No Brasil, a certificação do Plano de segurança é feita pelo CONPORTOS, entidade interministerial presidida pelo Ministério da Justiça. Existem ainda comissões estaduais que também participam do processo.

Portos do mundo inteiro, inclusive os do Brasil e da América Latina, devem se preparar para uma próxima fase de investimentos em segurança, que será marcada pela instalação de equipamentos sofisticados como scanners de raios gama para

\footnotetext{
${ }^{1}$ International Ship and Port Facility Security Code - ISPS CODE Por decisão da Autoridade Marítima, o termo inglês "security" foi traduzido por "proteção", para não criar confusão com "safety", já traduzido anteriormente por "segurança".
} 
inspeção não-intrusiva de contêineres. A adição de alta tecnologia nos portos, para prevenção de ataques terroristas, contrabando e tráfico de drogas, servirá de complemento às ações do Código ISPS.

Quanto às conseqüências comerciais, no caso de os portos brasileiros não cumprirem os prazos estabelecidos pelo Código ISPS, os EUA e a União Européia poderão usar esse fato para criar barreiras ao comércio exterior.

Estudos recentes do Ministério do Desenvolvimento, Indústria e Comércio Exterior indicam que o transporte marítimo é o mais utilizado no comércio internacional. Vê-se pelos dados da Tabela 1.1 que o modal aquaviário exerceu a liderança de utilização em 2006. A via marítima transportou 95,78\% das quantidades exportadas, representando $82,35 \%$ dos valores das exportações brasileiras.

Tabela 1.1: Modais de Transportes das Exportações Brasileiras - 2006

\begin{tabular}{|ccc|}
\hline \multicolumn{4}{c}{ Modais de Transporte das Exportações } & Brasileiras - 2006 \\
\hline Modal & \% - Fob & KUS $\$$ - Fob \\
\hline Aquaviário & 95,78 & $114.061 .213,27$ \\
Aeroviário & 0,16 & $8.875 .686,07$ \\
Ferroviário & 0,15 & $358.431,03$ \\
Rodoviário & 1,13 & $8.946 .976,09$ \\
Outros & 2,78 & $5.565 .163,04$ \\
& & \\
& & \\
\hline
\end{tabular}

Fonte: Ministério do Desenvolvimento, Indústria e Comércio Exterior - MDIC Secretaria de Comércio Exterior - SECEX - Sistema Alice

\subsection{LEI DE MODERNIZAÇÃO DOS PORTOS}

Promulgada pelo governo brasileiro em 25/02/93, a Lei $n^{\circ}$. 8.630/93 de Modernização dos Portos, fez com que os portos brasileiros passassem por grandes mudanças e desafios, como organizar o sistema de gerenciamento das operações e de mão-de-obra, eliminar o corporativismo e processos burocráticos e aproveitar, de forma racional, os espaços e instalações.

Dentre todos os avanços significativos, os resultados imediatos da implementação da Lei $n^{\circ}$. 8.630 foram: 
- A exploração dos portos organizados e das instalações portuárias;

- A substituição do setor público pelo setor privado nas operações portuárias, o que antes era exercido pela Administração do Porto Público, passou a ser executado por operadores portuários; e

- A quebra do monopólio dos sindicatos de trabalhadores avulsos no fornecimento e escalação da mão-de-obra para as operações portuárias com a constituição de 26 Órgãos Gestores de Mão-de-Obra (OGMO).

Ainda traçou três grandes eixos para realizar a transformação no sistema portuário brasileiro, promovendo a competição entre:

- Portos públicos (portos que se situam em uma mesma área de influência);

- Portos públicos e terminais de uso privativo (dentro ou fora do porto organizado); e

- Intraportos (entre terminais existentes no mesmo porto).

Por porto organizado entende-se aquele "construído e aparelhado para atender às necessidades da navegação, da movimentação de passageiros ou da movimentação e armazenagem de mercadorias, concedido ou explorado pela União, cujo tráfego e operações portuárias estejam sob a jurisdição de uma Autoridade Portuária". ${ }^{2}$

Operações portuárias são as atividades de movimentação e armazenagem de mercadorias destinadas ou provenientes de transporte aquaviário e devem ser executadas por operador portuário dentro da área do porto organizado.

Deu-se da concessão de serviço público a exploração de portos organizados, de modo que as operações portuárias, independentemente de que a exploração se faça por meio da iniciativa privada ou diretamente pelo Poder Público ou que tais operações se realizem dentro de instalações portuárias, de uso privativo ou não, desde que dentro dos limites do porto organizado.

Contou com a alteração nas jornadas de trabalho estipulou que o trabalho portuário de capatazia, estiva, conferência de carga, conserto de carga, bloco e vigilância de embarcações, nos portos organizados, fosse realizado por

${ }^{2}$ BRASIL. Lei 8.630/93, Lei de Modernização dos portos. Capítulo $1,1^{\circ}$ parágrafo. Disponível em: <http://www.planalto.gov.br/ccivil/leis/L8630.htm>. 
trabalhadores portuários com vínculo empregatício a prazo indeterminado e por trabalhadores portuários avulsos.

Nesse novo contexto, com os serviços portuários transferidos para o setor privado, as antigas companhias docas passaram a atuar como Autoridades Portuárias onde exercem prioritariamente os papéis de órgão regulador local, gestor de patrimônio e administrador portuário.

A Lei de Modernização também contribuiu para descentralização, pois instituiu do Conselho de Autoridade Portuária (CAP) o qual exerce uma co-gestão da atividade portuária e será abordada no item 2.1.7.

A Medida Provisória (MP) 369, de 7 de maio de 2007, criou a Secretaria Nacional de Portos com "status" de ministério. A secretaria criou um grupo que visa dar prioridade aos projetos previstos no Programa de Aceleração do Crescimento (PAC), e de acordo com o artigo publicado na Folha Online, o emprego da tecnologia como ferramenta integradora consta na pauta dessa secretaria, "O grupo também vai discutir instrumentos de troca de informações logísticas entre portos, rodovias e ferrovias, organização de banco de dados integrado e portal de informações."

Competirá à Secretaria Especial de Portos da Presidência da República, cujo organograma apresentado na Figura 1, de assessorar direta e imediatamente 0 Presidente da República na formulação de políticas e diretrizes para o desenvolvimento e o fomento do setor de portos marítimos e, especialmente, promover a execução e avaliação de medidas, programas e projetos de apoio ao desenvolvimento de infra-estrutura portuária marítima e dos portos outorgados às Companhias Docas.

\footnotetext{
3 "Brito promete diagnóstico e novos diretores para portos de Santos e RJ", artigo publicado na Folha Online, disponível em: <http://www1.folha.uol.com.br/folha/dinheiro/ult91u117210.shtml>
} 


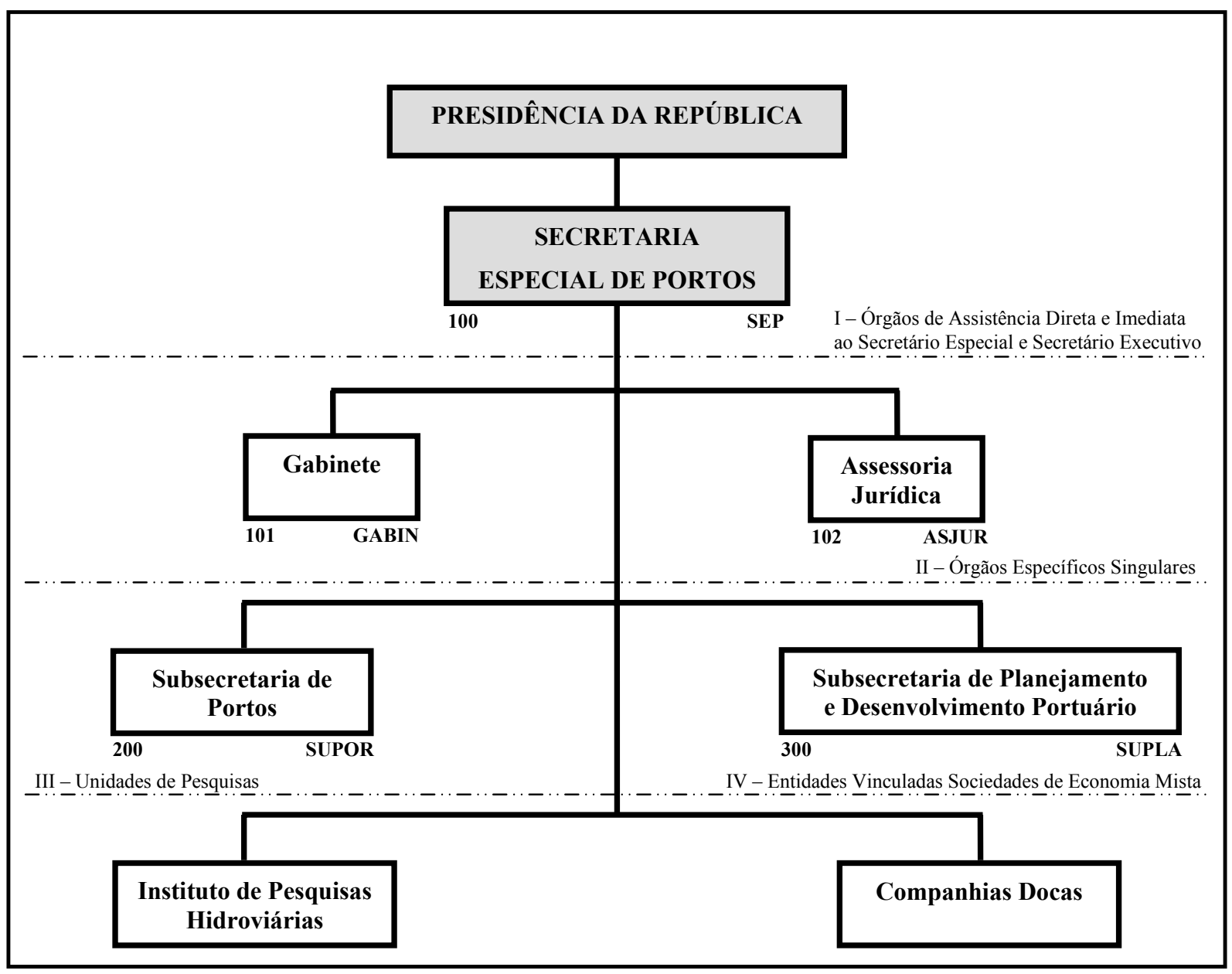

Figura 1: Organograma da Secretaria Especial de Portos da Presidência da República Fonte: Secretaria Especial de Portos.

\subsection{PLANO NACIONAL DE SEGURANÇA PÚBLICA PORTUÁRIA (PNSPP)}

A solução para o complicado e desafiador assunto da segurança exige o efetivo envolvimento de diferentes órgãos governamentais em todos os níveis, entidades privadas e sociedade civil. Buscou-se, com o estabelecimento de medidas integradas, para estimular e aperfeiçoar a atuação dos órgãos e instituições voltados à segurança pública nos portos, terminais e vias navegáveis, permitindo-lhes trabalhar em mútua cooperação. Através desta parceria, procurou-se criar condições para o desenvolvimento de ações mais eficazes.

Dentro desse contexto, visando dotar o Brasil com órgãos destinados, especificamente, à segurança dos portos, o Governo Brasileiro criou através do Decreto 1.507 de 30 de maio 1995 (alterado pelo Decreto 1.972 de 30 de julho de 1996) a Comissão Nacional de Segurança Pública nos Portos, Terminais e Vias 
Navegáveis (CONPORTOS) e as Comissões Estaduais de Segurança Pública nos Portos Terminais e Vias Navegáveis (CESPORTOS), para suprir dificuldades no setor de segurança, tais como:

- Conciliação de ações de rotinas funcionais com aquelas decorrentes do delito considerado;

- Carência de recursos humanos e de equipamentos essenciais;

- Nivelamento de assuntos tratados por setores diferentes da Administração Pública Federal e Estadual;

- Elaboração de estatísticas sobre atos ilegais realizados em áreas marítimas brasileiras não confiáveis, perante a falta de registro de delitos de pequeno vulto;

- Inviabilidade de investigações pelo fato de os comandantes não comunicarem os atos ilícitos ocorridos em seus navios às autoridades locais, em portos brasileiros e

- Difícil levantamento das investigações a partir de registros de atos ilícitos e com inquérito policial instaurado, pelo fato de as pessoas não residirem no país.

O Ministério da justiça e a CONPORTOS editaram a $1^{a}$. Edição do Plano Nacional de Segurança Pública Portuária em Dezembro de 2002, ANEXO A, onde no Capítulo I e Capítulo II está explicita a missão, composição e as atribuições da CONPORTOS E CESPORTOS respectivamente, sobre os seus compromissos no Capítulo III.

A partir de março de 2003, a CONPORTOS coordenou e normatizou, através de resoluções, o conjunto de ações que passaram a orientar as questões de segurança portuárias para atender o Código ISPS, o qual será explicado no capítulo 3, que deveriam estar implementadas a partir de $1^{\circ}$ de julho de 2004.

Por meio de resolução, a CONPORTOS solicitou a formação dos Supervisores de Segurança Portuária, modalidade de trabalhador recomendado pelo Código ISPS, com responsabilidade de interagir com os agentes públicos que exercem atividades portuárias e atuar sobre os planos de segurança das respectivas instalações portuárias, provendo ajustes de proteção entre navio/porto, onde atuem como multiplicadores de conhecimentos da nova concepção cultural sobre segurança pública portuária. 
Foram implementados 200 (duzentos) planos de Segurança Pública Portuária nas instalações portuárias nacionais. Deste total, 135 (cento e trinta e cinco) planos já estão plenamente implementados. Quinhentos e sessenta e seis (566) profissionais já foram formados pela Secretaria Nacional de Segurança Pública SENASP/CONPORTOS como Supervisores de Segurança Portuária, em seis edições do Curso Especial de Formação de Supervisores de Segurança Portuária realizados.

O Plano está estruturado para relacionar missões, competência e compromissos a serem assumidos pelos órgãos envolvidos. Essas informações serão detalhadas a seguir. 


\section{ATORES DO SISTEMA PORTUÁRIO PARA PNSPP}

\subsection{AGENTES GOVERNAMENTAIS}

Coube à CONPORTOS /CESPORTOS a realização de Estudos de Avaliação de Risco e elaboração dos seus respectivos Planos de Segurança Pública Portuária.

A composição do PNSPP terá, quando de sua operação total, a integração da Autoridade Portuária com atores de setores privados como os Operadores Marítimos, Agências Marítimas e OGMO e as Autoridades como os Ministérios do Transporte, Fazenda, Defesa, Justiça e Saúde.

Serão especificadas, a seguir, as competências dos agentes governamentais acima citados em relação à segurança portuária, bem como as do governo Estadual e do CAP.

\subsubsection{SECRETARIA ESPECIAL DE PORTOS / ADMINISTRAÇÃO PORTUÁRIA}

À Administração Portuária por meio de sua Guarda Portuária não cabe somente vigiar as instalações prediais da Administração Portuária, como executar o policiamento interno, como também zelar pela segurança das pessoas, cargas, mercadorias e as vias pública do porto organizado.

Suas competências estão explicitadas no ANEXO A - Capítulo II- item 3-b. 4.

\subsubsection{MINISTÉRIO DA FAZENDA / SECRETARIA DA RECEITA FEDERAL}

Por meio da Secretaria da Receita Federal (SRF) vinculada aos Órgãos Específicos Singulares do Ministério da Fazenda, deve efetivar-se a fiscalização e o controle sobre o comércio exterior, essenciais à defesa dos interesses fazendários nacionais. A ela compete: (Artigo 237 da Constituição Federal). 
Suas competências estão explicitadas no ANEXO A - Capítulo II- item 3-b. 3.

\subsubsection{MINISTÉRIO DA DEFESA / CAPITANIA DOS PORTOS}

A Capitania dos Portos, órgão da Diretoria de Portos e Costas da Marinha do Brasil e vinculada ao Ministério da Defesa, é responsável pela aplicação das normas de segurança e reguladores do tráfego aquaviário nas águas sob jurisdição nacional, de acordo com a Lei n. 9537/1997.

Suas competências estão explicitadas no ANEXO A - Capítulo II- item 3-b. 2.

\subsubsection{MINISTÉRIO DA JUSTIÇA / POLÍCIA FEDERAL}

Cabe à Polícia Federal, órgão vinculado ao Ministério da Justiça à responsabilidade pelos trâmites pertinentes ao trânsito do pessoal embarcado (tripulantes e passageiros) e a repressão ao contrabando. Compete ao Departamento de Polícia Federal (DPF) presente as determinações constitucionais e o caráter policial das funções de PMAF (Polícia Marítima, Aérea e de Fronteiras), estabelecer e executar medidas preventivas e repressivas dos atos ilícitos praticados nos portos e a fiscalização da segurança dos portos. De acordo com o Convênio $n^{\circ}$. 01/98 firmado entre os Ministérios da Justiça (Departamento de Polícia Federal) e Ministério da Defesa (Marinha do Brasil/Estado-Maior da Armada), celebrado em 07/08/98.

Suas competências estão explicitadas no ANEXO A - Capítulo II- item 3-b. 1.

\subsubsection{GOVERNO ESTADUAL}

De acordo com o Artigo 144 da Constituição da República Federativa do Brasil, compete ao Governo do Estado, através da Polícia Civil, Polícia Militar e Corpo de Bombeiros que estão explicitadas no ANEXO A - Capítulo Il- item 3-b. 5. 


\subsubsection{MINISTÉRIO DA SAÚDE / ANVISA}

A Agência Nacional de Vigilância Sanitária - ANVISA - criada pela Lei $n^{\circ}$ 9.782, de 26 de janeiro de 1999 e vinculada ao Ministério da Saúde, é uma autarquia sob regime especial, ou seja, é uma agência reguladora, embora não esteja relacionada anteriormente a CONPORTOS/CESPORTOS.

A ANVISA atua nas áreas de fronteira e no controle de portos e aeroportos junto ao Ministério das Relações Exteriores e instituições estrangeiras para cuidar de assuntos internacionais na área de vigilância sanitária.

Conforme o estabelecido na Resolução-RDC n. 217, de 21 de novembro de 2001, é exigida das embarcações fluviais, lacustres e marítimas, a documentação sanitária para saber se estão em condições higiênico-sanitárias satisfatórias para que possam trafegar em território nacional.

"A Documentação Sanitária exigida e obrigatória consta de:

- Declaração Marítima de Saúde;

- Lista de Viajantes, com o respectivo local e data de embarque;

- Formulário para informações sobre água de lastro.

A embarcação deverá dispor a bordo:

- Certificado Internacional ou Nacional de Desratização ou de Isenção;

- Certificado de Vacinação Internacional contra Febre Amarela;

- Lista de Medicamentos, submetidos ao controle especial;

- Certificado de Livre Prática de outro porto nacional; 
- Manifesto de Carga;

- Comprovante de pagamento de Taxa de Fiscalização de Vigilância Sanitária;

- Informações referentes à água potável, efluentes sanitários e resíduos sólidos.

O órgão de vigilância sanitária federal competente emite uma autorização chamada Livre Prática para que uma embarcação procedente ou não do exterior, atraque ou inicie as operações de embarque e desembarque de cargas e viajantes, podendo ser:

- A Bordo: aquela a ser emitida a bordo, após inspeção sanitária.

- Via Rádio: aquela a ser emitida a partir da avaliação satisfatória das informações apresentadas na Solicitação de Certificado, sem inspeção sanitária, a bordo, no momento da sua emissão.

Sobre a concessão e emissão da Livre Prática pontuamos as seguintes informações:

- Quanto à sua solicitação: $24 \mathrm{~h}$ antes da E.T.A. "Estimated Time of Arrival", através do formulário de Solicitação de Certificado vide ANEXO B.

- Quanto ao prazo de validade: poderá ser de 90 dias ou somente vigorar durante o tempo de atracação no porto.

- Quanto ao critério: é feita uma avaliação da Solicitação do Certificado para determinar o tipo de Livre Prática a ser concedido à embarcação. $O$ preenchimento completo desta solicitação possibilita a emissão de Certificado de Livre Prática via rádio, o que agiliza a imediata operação da embarcação no porto.

- Quanto às isenções: tipo esporte e recreio, com fins não comerciais, em trânsito nacional tipo pesca, com saída e retorno ao mesmo porto, sem realizar escalas intermediárias e as plataformas constituídas de instalação de estrutura fixa." ${ }^{4}$

\footnotetext{
${ }^{4}$ Agência Nacional de Vigilância Sanitária, Ministério da Saúde, disponível em: $<\underline{\text { http://www.anvisa.gov.br/paf/portos/embarcacoes.htm }>}$
} 


\subsubsection{CONSELHO DE AUTORIDADE PORTUÁRIA}

Conforme art. 31, Seção I do Conselho de Autoridade Portuária (CAP), Capítulo VI da Administração do Porto Organizado da Lei n. 8630 o CAP é constituído por quatro blocos: Poder Público, Operadores Portuários, Classe dos trabalhadores Portuários e Usuários dos Serviços portuários e afins, detalhados a seguir.

I. bloco do poder público, sendo:

a. um representante do Governo Federal, que será o Presidente do Conselho;

b. um representante do Estado onde se localiza o porto;

c. um representante dos Municípios onde se localiza o porto ou os portos organizados abrangidos pela concessão;

II. bloco dos operadores portuários, sendo:

a. um representante da Administração do Porto;

b. um representante dos armadores;

c. um representante dos titulares de instalações portuárias privadas localizadas dentro dos limites da área do porto;

d. um representante dos demais operadores portuários;

III. bloco da classe dos trabalhadores portuários, sendo:

a. dois representantes dos trabalhadores portuários avulsos;

b. dois representantes dos demais trabalhadores portuários;

IV. bloco dos usuários dos serviços portuários e afins, sendo:

a. dois representantes dos exportadores e importadores de mercadorias;

b. dois representantes dos proprietários e consignatários de mercadorias;

c. um representante dos terminais retroportuários 
$\S 1^{\circ}$ Para os efeitos do disposto neste artigo, os membros do Conselho serão indicados:

I. pelo ministério competente, Governadores de Estado e Prefeitos Municipais, no caso do inciso I do caput deste artigo;

II. pelas entidades de classe das respectivas categorias profissionais e econômicas, nos casos dos incisos II e III do caput deste artigo;

III. pela Associação de Comércio Exterior (AEB), no caso do inciso IV, alínea a do caput deste artigo;

IV. pelas associações comerciais locais, no caso do inciso IV, alínea b do caput deste artigo.

$\S 2^{\circ}$ Os membros do conselho serão designados pelo ministério competente para um mandato de dois anos, podendo ser reconduzidos por igual ou iguais períodos.

$\S 3^{\circ}$ Os membros do conselho não serão remunerados, considerando-se de relevante interesse público os serviços prestados.

$\S 4^{\circ}$ As deliberações do conselho serão tomadas de acordo com as seguintes regras:

I. cada bloco terá direito a um voto;

II. o presidente do conselho terá voto de qualidade.

$\S 5^{\circ}$ As deliberações do conselho serão baixadas em ato do seu presidente

Algumas da competência do CAP são:

- Regulamentar a exploração do porto;

- Homologar o horário de funcionamento do porto;

- Promover a racionalização e a otimização do uso das instalações portuárias;

- Homologar os valores das tarifas portuárias;

- Assegurar o cumprimento das normas de proteção ao meio ambiente;

- Estimular a competitividade;

- Pronunciar-se sobre outros assuntos de interesse do porto. 


\subsection{ENTIDADES NÃO GOVERNAMENTAIS}

A seguir é detalhado como cada entidade não governamental é constituída, como atua e sua responsabilidade dentro da comunidade portuária. No capítulo V, será mostrado como eles atuaram no Sistema de Segurança Pública Portuária (SSPP).

\subsubsection{ORGÃO GESTOR DE MÃO DE OBRA (OGMO)}

Os OGMO atuam como gestores dos cadastros e registros de Trabalhadores Portuários Avulsos - TPA - sendo o único com o poder de controlar os rodízios e efetuar o ponto de requisição de mão-de-obra portuária.

Os TPA são tidos, pela legislação nacional, como aqueles sem vínculo empregatício com o contratante e que, por meio de rodízio gerenciado pelos OGMO, fazem os serviços nas áreas de porto organizado de modo exclusivo, na movimentação das embarcações e nas instalações relacionadas.

Os TPA prestam seus serviços aos operadores que atuam na área de porto organizado, sendo requisitados previamente, ou não, aos OGMO por operadores portuários; realizam toda a movimentação de mercadorias provenientes ou encaminhadas aos navios, com o consentimento da administração legal do órgão gestor de mão-de-obra.

"É de sua responsabilidade:

- A movimentação de cargas (embarque ou desembarque);

- Arrumação;

- Transbordo;

- Peação e despeação, realizadas nos porões e/ou conveses das embarcações (operações típicas da estiva);

- Movimentação de cargas realizadas no costado do navio na faixa do cais, nos armazéns e nas instalações portuárias (próprias da capatazia). 
O OGMO administra as seguintes categorias de TPA:

- Estivadores: trabalhadores que atuam na movimentação da carga no interior das embarcações, efetuando a estivagem e desestivagem da carga;

- Conferentes: encarregados do planejamento, da verificação de quantidades, marcas e lotes das cargas embarcadas ou desembarcadas dos navios;

- Consertadores: especializados nos reparos das embalagens avariadas;

- Bloquistas: encarregados de serviços tais como: peação e despeação da carga, forração, retirada de madeira ou limpeza em geral;

- Vigias portuários: responsáveis pela vigilância a bordo das embarcações;

- Arrumadores: trabalham no costado, preparando a carga a ser movimentada;

- Guindasteiros: especializados na operação dos guindastes de terra."

Para cada tipo de carga existe um acordo entre os sindicatos dos operadores e os sindicatos dos trabalhadores avulsos, estabelecendo o número mínimo de trabalhadores a serem requisitados para as movimentações de carga e descarga.

\subsubsection{OPERADOR PORTUÁRIO}

O operador portuário é responsável pela operação de carga e descarga de um navio na área do porto organizado, utilizando a mão-de-obra fornecida pelo OGMO.

Sua atividade deve estar qualificada perante a Administração do Porto, na forma de norma publicada pelo Conselho de Autoridade Portuária com exigências claras e objetivas. O operador portuário assume responsabilidades perante várias instâncias.

Assim, responde:

- À Administração do Porto pelos danos causados à infra-estrutura, às instalações e ao equipamento que se encontre a seu serviço ou sob sua guarda;

\footnotetext{
${ }^{5}$ BAUMGARTEN, Marcelo Zepka. Impacto da Lei n $8.630 / 93$ nas dinâmicas portuárias e relações internacionais brasileiras. Disponível em:

<http://jus2.uol.com.br/doutrina/texto.asp?id=8674>.
} 
- Ao proprietário, o consignatário da mercadoria, pelas perdas e danos que ocorram durante as operações;

- Ao armador pelas avarias provocadas na embarcação ou na mercadoria;

- Ao trabalhador portuário pela remuneração dos serviços prestados e respectivos encargos;

- Ao Órgão Gestor de Mão-de-Obra - OGMO, local do trabalho avulso pelas contribuições não recolhidas e os órgãos competentes pelo recolhimento dos tributos incidentes sobre o trabalho portuário avulso.

\subsubsection{AGENTE MARÍTIMO}

Representante do armador no país, responde perante as autoridades pelas obrigações das embarcações que agência, perante a alfândega e demais organismos governamentais envolvidos nas operações de atracação e desatracação de embarcações, carga e descarga de mercadorias, embarque e desembarque de passageiros e tripulantes.

Cabe ao agente Marítimo, na entrada de toda embarcação no porto, solicitar, à autoridade sanitária, a concessão de Livre Prática, que deverá ser feita pelo representante ou proprietário da embarcação. Também outros documentos são necessários como os que estão sempre associados a uma chegada ou a uma partida de um navio como Manifesto de Carga/BL, Requisição e Prioridade e Atracação, Declaração das provisões de bordo, Lista da tripulação, Lista de passageiros, Declaração dos bens da tripulação, Declaração marítima de saúde. 


\section{CÓDIGO INTERNACIONAL PARA PROTEÇÃO DE NAVIOS E INSTALAÇÕES PORTUÁRIAS (CÓDIGO ISPS)}

\subsection{INTRODUÇÃO DO CÓDIGO ISPS}

Para acompanhar a definição do Código ISPS é necessário reportar-se à Organização Marítima Internacional (IMO) que, seguindo o modelo das outras organizações da ONU, consiste numa Assembléia formada por representantes de todos os Estados-Membros das organizações não governamentais com estatuto consultivo, entre os quais se encontra, atualmente, a Comissão Européia.

Nas sessões da Assembléia, o Conselho ${ }^{6}$ desempenha o papel de órgão de direção. É constituído por 40 membros, conforme Figura 2, eleitos por dois anos e distribuídos por três categorias:

\section{Composição do Conselho da IMO}

A IMO indica que a eleição dos membros do Conselho, deve respeitar os seguintes critérios:

(a) Dez devem ser Estados com grande interesse nos serviços internacionais de transporte;

(b) Dez outros Estados com grande interesse no comércio marítimo internacional e

(c) Vinte Estados não eleitos pelas categorias (a) e (b) que tenham especiais interesses no Transporte marítimo ou navegação e cuja eleição ao Conselho assegure uma Representação das maiores áreas do mundo.

Os Membros do Conselho eleitos na 24a Assembléia para 2006 e 2007 são os seguintes:

(a) China Grécia, Itália, Japão, Noruega, Panamá, República da Coréia, Federação Russa, Reino Unido, Estados Unidos;

(b) Argentina, Bangladesh, Brasil, Canadá, França, Alemanha, Índia, Holanda, Espanha, Suécia; e

(c) Algéria, Austrália, Bahamas, Bélgica, Chile, Chipre, Dinamarca, Egito, Indonésia, Quênia, Malásia, Malta, México, Nigéria, Filipinas, Polônia, Portugal, Arábia Saudita, Singapura, África do Sul, Tailândia, Turquia.

Figura 2: Composição Conselho da IMO

Fonte: sítio da Organização Marítima Internacional, www.imo.org.

\footnotetext{
${ }^{6}$ Novo conselho eleito para o biênio de 2006 e 2007 pela assembléia da IMO , sitio da Organização Marítima Internacional (IMO). Disponível em : <http://www.imo.org >
} 
A Convenção Salvaguarda da Vida no Mar (SOLAS) $)^{7}$ é a mais importante e a mais abrangente de todas as convenções da IMO. Criada em 1912, foi ratificada por treze países após o naufrágio do Titanic; entrou em vigor em 1929,1948 e 1960, sendo esta última revisão sob coordenação da IMO. Modificada em 1974 e complementada por dois protocolos em 1978 e 1988, concerne ao mesmo tempo os equipamentos dos navios, as regras de segurança a cumprir, os procedimentos de alerta e de socorro, e controles do porto pelo Estado, etc.

A SOLAS confere ainda mais peso às novas medidas adotada ao Código ISPS como uma nova parte do Capítulo XI.

A forma encontrada foi proceder a alterações à Convenção SOLAS, quer ao Capítulo V - designado como capítulo da "SAFETY" -, quer alterando o Capítulo XI - que sendo já o da "SECURITY", agora com uma característica mais reforçada. Além do mais, o Capítulo XI foi renumerado como XI-1, tendo sido acrescentado o $\mathrm{XI}-2$ o qual introduz o Código ISPS.

O Código ISPS é um conjunto de medidas definidas pela IMO com vistas a melhorar a segurança dos navios e das instalações portuárias (terminais); tem como principais objetivos: constituir um quadro internacional de cooperação entre os Governos-contratantes da SOLAS, os órgãos públicos, as administrações locais e os setores portuário e dos transportes marítimos, visando identificar ameaças à segurança e tomar medidas para prevenção de incidentes que possam afetar a segurança dos navios ou das instalações portuárias utilizado(a)s no tráfego internacional. Tem, por intenção, estipular responsabilidades e funções daqueles intervenientes a nível nacional e internacional para garantir a segurança do transporte marítimo e proporcionar uma metodologia de avaliação da segurança, que oriente a elaboração de planos e procedimentos de segurança para o mesmo fim.

O capítulo XI-2 da adoção do Código Internacional para Proteção de Navios e Instalações Portuárias divide-se em duas partes:

Parte A - Requisitos obrigatórios relativos às disposições do capítulo XI-2 da Convenção Internacional para Salvaguarda da Vida Humana No Mar de 1974;

$\overline{{ }^{7} \text { SOLAS - Safety of Life at Sea }}$ 
Parte B - Diretrizes relativas às disposições do capítulo XI-2 do anexo à Convenção Internacional para a Salvaguarda da Vida Humana no Mar, de 1974.

O Código ISPS ${ }^{8}$ estabelece no aspecto importante 3 níveis de segurança em que os navios e as instalações portuárias deverão operar, conforme as ameaças identificadas em cada caso.

- Nível 1 de Proteção, normal; o nível no qual os navios e instalações portuárias normalmente operam;

- Nível 2 de Proteção, elevado; o nível aplicável enquanto houver um risco elevado de um incidente de proteção; e

- Nível 3 de Proteção, excepcional; o nível aplicável pelo período durante o qual há um risco provável ou iminente de um incidente de proteção.

Segundo a IMO, para os 162 países signatários, o ISPS Code passou a ser obrigatório (incluindo o Brasil), sendo $1^{\circ}$ de julho de 2004 a data limite para sua implantação. $69 \%$ dos portos mundiais já haviam implementado as novas regras para o plano de segurança

\subsection{CÓDIGO ISPS NOS PORTOS BRASILEIROS}

A adaptação ao Código ISPS se inicia pela identificação dos pontos vulneráveis a ataques à infra-estrutura portuária, além do acesso ao porto em questão. São avaliadas áreas que poderiam ser alvo de grupos de terror quanto à integridade da sua estrutura.

Através da resolução $n^{0} .12$ de 18 de dezembro de 2003 do Ministério da justiça, foi elaborado um "Roteiro para Elaboração e Análise dos Planos de Segurança Pública Portuária - RPPS" (ANEXO C) e orientação para elaboração das "Normas de Controle de Acesso e circulação de pessoas e veículos - NAPV" ambos

\footnotetext{
${ }^{8}$ Adoção do Código Internacional para a Proteção de Navios e Instalações Portuárias, Parte B, p.34 Disponível em: < http://www.comissaoportos.com.br/downloads/ISPS_Code_port_05142003.pdf >
} 
enviados para as instalações portuárias, para efetuarem um estudo de avaliação de risco; que em seguida, foram enviados à CONPORTOS.

Cabe à CONPORTOS verificar se o porto concluiu ou não suas obras físicas e se a segurança do local está de acordo ou não com o Plano de Segurança aprovado; se o cronograma em andamento está ou não dentro dos prazos. Quando o resultado é positivo, a CONPORTOS concede a certificação definitiva com Declaração de Cumprimento (DC) ou com Termo de Aptidão (TA) "Certificado Provisório" com validade de 6 meses.

Quando a Instalação Portuária e o Navio concordam com as seguintes medidas de segurança e responsabilidades para assegurar o cumprimento aos requisitos da Parte A do Código "ISPS", um documento chamado Declaração de Proteção (ANEXO D) é assinado pelo Oficial de Proteção do Navio (SSO) e do Supervisor de Segurança da Instalação Portuária (PFSO) o qual indica que a atividade será executada, de acordo com o Plano de Segurança da Instalação Portuária, aprovado pela CONPORTOS.

Em julho de 2005 o Governo Federal divulgou a liberação R\$ 100 milhões para se adaptar às novas normas internacionais de segurança marítima e deve, nos próximos dois anos, investir mais $\mathrm{R} \$ 150$ milhões.

Do valor já liberado, ao Ministério dos Transportes foi destinado $\mathrm{R} \$ 57,3$ milhões, sendo R\$ 20 milhões para o porto de Santos, o maior do País; R\$ 39,5 milhões couberam à Polícia Federal para a instalação de bases da Polícia Marítima em 12 estados e $\mathrm{R} \$ 3,2$ milhões para a Marinha, com vistas à instalação de sistemas de alerta de segurança nos navios.

Quase $80 \%$ dos portos e terminais brasileiros por onde trafegam navios de bandeiras estrangeiras já estão total ou parcialmente adaptados às novas regras do ISPS Code contra o terrorismo, o que prevê a instalação de câmeras, cercas e muros para isolamento, catracas, aparelhos de identificação de pessoas, máquinas de raios-X e treinamento de funcionários, entre outras medidas.

Em 13 de março de 2007 a CONPORTOS, através dos dados atualizados no seu sítio ${ }^{9}$, cita que 211 instalações portuárias já receberam a certificação em razão de ter implementado ou estar implementando o ISPS Code.

\footnotetext{
${ }^{9}$ Instalações Portuárias - "Status Geral", Comissão Nacional de Segurança Pública nos Portos, Terminais e Vias Navegáveis - CONPORTOS, Ministério da Justiça, Defesa (Marinha do Brasil), Fazenda, Relações Exteriores e Transportes. Disponível em:

$<$ http://www.mj.gov.br/senasp/conportos/documentos/conportos_instalacoes_certificadas.pdf $>$
} 
Conforme a resolução $\mathrm{n}^{\circ}$. 37 da CONPORTOS, de 21 de junho de 2005, a primeira auditoria será realizada, obrigatoriamente, no prazo de até 03 (três) anos, contado de $1^{\circ}$ de julho de 2004, data em que passou a vigorar o Código ISPS, ou seja, a partir de julho de 2007. Até lá, todas as instalações já certificadas deverão realizar, obrigatoriamente, auditorias internas de implementação do Código, também atendendo às suas exigências. 


\section{OUTROS DESENVOLVIMENTOS NO CONTEXTO DA "SECURITY"}

\subsection{CERTIFICADO INTERNACIONAL DE PROTEÇÃO DO NAVIO (ISSC)}

No Capítulo XI-2 Parte A do Plano de Proteção do Navio da SOLAS aos navios é exigida a existência a bordo do Certificado Internacional de Segurança do Navio "ISSC - Internacional Ship Security Certificate" que atesta o cumprimento das normas pertinentes estabelecidas na seção 19.1. Para obtenção deste certificado, o Funcionário de Proteção da Companhia deve assegurar que o navio tem implementado as normas de segurança a que está obrigado. Entre diversas obrigações, o comandante do navio deverá designar um Oficial de Proteção do Navio responsável pela implementação e manutenção do plano, o qual será o elo de ligação entre o funcionário de proteção da companhia e os funcionários das instalações portuárias. Sem este certificado, os navios podem ser sujeitos a diversos procedimentos e medidas que prejudicam a sua operação como inspeções, retardamento ou retenção, restrição das suas operações ou até a expulsão do porto. Por outro lado, se houver conhecimento de que, antes de entrar no porto o navio não cumpre o Código, este pode ser impedido de atracar, até que o plano seja cumprido.

Um país pode ter responsabilidade como Estado de Bandeira (Flag State), garantindo o cumprimento dos procedimentos por parte dos navios e tripulação; assim como Estado Costeiro (Coastal State) ou Estado do Porto (Port State), prevenindo-se tanto contra a importação quanto à exportação não intencional de organismos nocivos e patogênicos.

Para que os navios brasileiros obtenham o ISSC para atender aos requisitos de segurança do transporte aquaviário, a salvaguarda da vida humana no mar, a Marinha do Brasil $^{10}$ mantém uma ampla rede de 59 agências, de diversos portes, distribuídas em portos marítimos e fluviais, de modo a assegurar que, em qualquer área onde ocorra o transporte aquaviário, possam dispor de equipes que

\footnotetext{
${ }^{10}$ Ministério da Defesa, Diretoria de Portos e Costas, NORMAN 4, Capítulo 3, Controle de Navios pelo Estado do Porto. Disponível < https://www.dpc.mar.mil.br/normam/N_04/N04cap3.pdf>
} 
desenvolvam as atividades de inspeções navais de "Port State Control" (para navios estrangeiros) e de "Flag State Control" (navios nacionais) as quais os navios são submetidos, regularmente.

\subsection{SISTEMA AUTOMÁTICO DE IDENTIFICAÇÃO (AIS)}

Este sistema, incorporado pelas emendas ao SOLAS, no Capítulo 5 (Segurança da Navegação), Regra 19, adotadas em dezembro de 2000, com entrada em vigor em $1^{\circ}$ de julho de 2002, estabeleceu a obrigatoriedade de utilização de um transponder de $\mathrm{AIS}^{11}$ (Automatic Identification System) com características e comportamento bem definidos para navios grandes, construídos depois de 2002 e, gradativamente, para navios mais antigos, até 2008. Tais convenções estabelecem que cada governo deva assegurar, com os recursos necessários, a vigilância em suas costas e o salvamento de vidas humanas em perigo no mar, criando áreas de responsabilidade $\mathrm{SAR}^{12}$ para alguns países; dentro dessas áreas, os respectivos países responsáveis devem auxiliar e dar apoio a eventuais necessidades dos Navios Mercantes - NM quanto à sua segurança e, ainda, que cada país deve implementar um sistema de controle de posição dos navios que estiverem navegando dentro da respectiva área SAR, para facilitar as “operações SAR" decorrentes.

AIS é um sistema de um conjunto integrado de componentes composto de equipamento AIS ou "transponder AIS", um modem de alta freqüência, um computador e um software gráfico que processa as informações recebidas pelo equipamento, gerando um arquivo para transmissão ou recepção de mensagens de dados digitais padronizadas para o Comando do Controle Naval do Tráfego Marítimo - COMCONTRAM via e-mail, pela intranet/internet, nas instalações localizadas em pontos fixos, distribuídas ao longo da costa brasileira, ou transmissão de mensagem por HF, via Estações Rádio da Marinha, quando os navios da Marinha do Brasil - MB estiverem em patrulha no mar.

\footnotetext{
${ }^{11}$ Regulamentions of AIS Transponders, sitio da Organização Marítima Internacional IMO.

Disponível em < http://www.imo.org/Safety/mainframe.asp?topic_id=754>

12 SAR - Do inglês Search and Rescue, busca e salvamento.
} 
O grande benefício da mensagem AIS é que ela permite um preciso acompanhamento, com um tempo de atualização menor, o que tem contribuído para o aumento da quantidade e qualidade de informações processadas pelo Sistema de Informações sobre o Tráfego Marítimo - SISTRAM, aumentando a precisão e confiabilidade dos dados coletados (CUNHA,2006).

A adesão em grande parte dos NM ao SISTRAM é normatizada pelas Normas da Autoridade Marítima para Tráfego e Permanência de Embarcações em Águas Jurisdicionais Brasileiras (NORMAM-08), que determina a obrigatoriedade da adesão dos NM de bandeira brasileira e os afretados por armadores brasileiros, em navegação de longo curso ou de cabotagem, navegando em águas internacionais.

Com relação aos NM de bandeira estrangeira, também convidados a aderir o SISTRAM desde sua entrada em área de responsabilidade SAR do Brasil, tornandose obrigatória a adesão quando estão navegando no mar territorial ou em águas interiores brasileiras.

O SISTRAM, desde que foi integrado ao Projeto AIS da MB, tem acompanhado cerca de 1.100 NM por dia e a tendência é aumentar, na medida em que novos equipamentos AIS sejam instalados nos navios e, também, em novos pontos de terra, visando à cobertura de todo o litoral brasileiro. Dessa forma o SISTRAM alimenta com as informações de posicionamento dos NM o Sistema Naval de Comando e Controle - SISNC2, são elas (CUNHA, 2006):

1) Previsão de tráfego marítimo para apoio ao $S A R$;

2) Previsão de chegada de navios nos portos;

3) Previsão de tráfego em áreas marítimas;

4) Previsão de tráfego marítimo para a II Força Aérea;

5) Informações de movimentação de NM para as águas jurisdicionais de países pertencentes ao plano de Coordenação da Defesa do Tráfego Marítimo Interamericano - CODEFTRAMI; e

6) Informações de movimentação de NM para órgãos federais (Agência Nacional de Transportes Aquaviários - ANTAQ - e Departamento de Polícia Federal - DPF).

O sistema tem sofrido um processo de aprimoramento e atualização constante que Ihe permite estar preparado para o recebimento de novas fontes de 
informações, mediante rápida integração e fusão de informações, a partir de um único banco de dados.

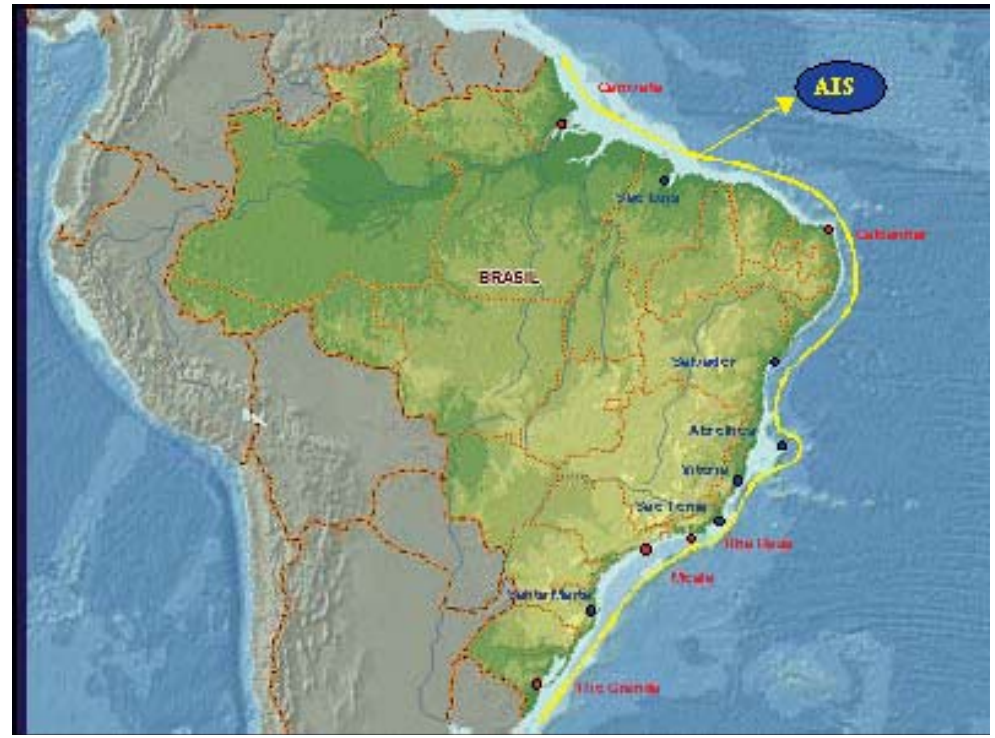

Figura 3: Distribuição de AIS em pontos de terra Fonte: Revista Passadiço da Marinha do Brasil

\subsection{SISTEMA DE IDENTIFICAÇÃO E ACOMPANHAMENTO DE NAVIOS A LONGA DISTÂNCIA (LRIT)}

O Capítulo V da Convenção SOLAS diz, da Regra V/19-1 estabelecendo o Sistema de Identificação e Acompanhamento de Navios a Longa Distância (LRIT Long Range Identification and Tracking of Ships ${ }^{13}$, com entrada em vigor prevista para $1^{\circ}$ de julho de 2008: LRIT um sistema que permite saber com grande antecedência ameaças relacionadas a "security", sistema que transmite automaticamente informações relativas à identificação e ao seguimento de longo alcance do navio.

Um outro aspecto a referir é a confiabilidade dos dados recolhidos pelo sistema. Este sistema permitirá, através do recolhimento de informação por satélites, o carregamento de bases de dados que ficarão entregues à organização, sob as

\footnotetext{
${ }^{13}$ Regulamentions of Long range identification and tracking (LRIT), sitio da Organização Marítima Internacional - IMO.

Disponível em <http://www.imo.org/Safety/mainframe.asp?topic_id=905>
} 
normas da IMO. A gestão do sistema e como a informação será disponibilizada serão de acordo com os trâmites acordado por cada Estado participante. A Figura 4 mostra a arquitetura do sistema LRIT proposta pela IMO:

\section{LRIT System Architecture}

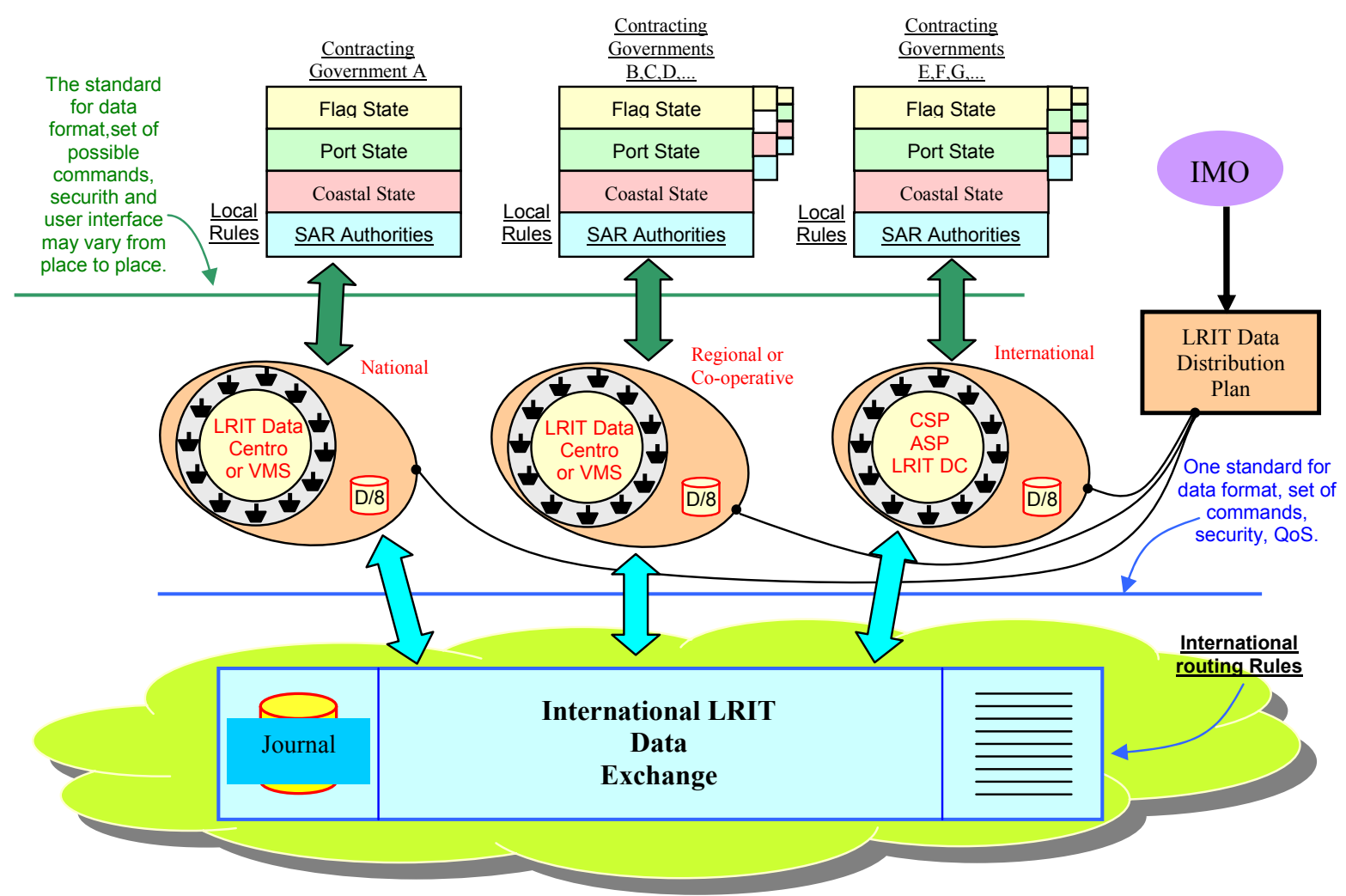

Figura 4: Arquitetura do Sistema LRIT.

Fonte: www.imo.org

O Brasil mantém o acompanhamento da movimentação de navios mercantes de bandeira brasileira, sujeitos a regulamentação SOLAS, através de informações padronizadas de posição, fornecidas pelos provedores de sistemas de acompanhamento (tracking). A implantação do LRIT e seus respectivos Centros de Dados permitirão o oportuno intercâmbio de informações entre os sistemas de controle do tráfego marítimo dos países signatários da Convenção SOLAS para uso em seus sistemas SAR e para a identificação do tráfego marítimo de interesse. 


\subsection{SISTEMA DE GERENCIAMENTO DO TRÁFEGO DE NAVIOS (VTMIS)}

Os sistemas de controle de tráfego marítimo (VTS) são constituídos por estações costeiras e portuárias, que controlam a navegação visualmente, por radar, por radio e por telecomunicações, assegurando a detecção 24 horas por dia, sob quaisquer condições atmosféricas. A adição de informações como administrativa, comercial, meteorológica e geográfica agregam valor para o VTS, que passa a designar-se Sistema de Informação e Gestão de Tráfego (VTMIS - Vessel Traffic Management and Information).

A implementação do VTMIS permitirá que os portos brasileiros monitorizem o tráfego marítimo conforme as orientações da IMO. O VTMIS será implantado para:

1) Preparar a escala: alocação de berços, preparação de operações;

2) Organizar a escala em conexão com as companhias portuárias (pilotagem, reboques, estivadores, serviços para os navios), por meio de gravação e difusão do ETA (tempo estimado de chegada) e do ETD (tempo estimado de partida) dos navios, e por difusão dos quadros de horários dos navios em um provedor na Internet;

3) Rastrear os movimentos dos navios desde a chegada nos ancoradouros para atracação, de forma a facilitar o tráfego marítimo e aumentar a segurança das operações portuárias;e

4) Os serviços de pesquisa necessários aos profissionais envolvidos na preparação e organização do trânsito de cargas no porto.

\subsection{EVOLUÇÃO E UTILIZAÇÃO DO CONTEINER}

Há cinqüenta anos atrás, mais precisamente em 26 de abril de 1956, um americano chamado Malcom McLean fez fortuna no transporte marítimo introduzindo uma nova técnica para transporte de cargas a bordo de navios mercantes. Apesar de haver registros anteriores da utilização de contêineres, seu uso foi difundido a partir de suas experiências. 
Graças aos contêineres, os portos viram sua produtividade avançar rapidamente a partir de 1970 e ajudaram a deslanchar o comércio global. O impacto no comércio foi irreversível.

O conteiner utiliza o conceito de cargas unitizadas, utilizadas no transporte internacional, que são formadas a partir do agrupamento de várias cargas de diferentes pesos, e de tamanhos pequenos e médios, em unidades de manuseio homogênea de forma a facilitar sua manipulação e o rápido escoamento. Evidentemente, que além de maior rapidez na manipulação, tem-se também maior segurança para as cargas e racionalização dos custos de sua movimentação.

Em princípio, praticamente qualquer mercadoria é conteinerizavel e a sua conteinerização depende de diversos fatores como custo, destino, rapidez nas operações, disponibilidade de transporte e equipamentos, tamanhos e peso do produto, aceitação pelo comprador, etc (KEEDI e MENDONÇA, 2000, p. 73). Com efeito, as companhias marítimas quando as cargas são conteinerizadas adotam tarifas especiais.

O conteiner proporciona uma redução nos gastos com embalagens e dispensa o uso de armazéns, pois seu peso ou o volume externo do conteiner não é computado no frete. Garante um manejo rápido, eficiente na operação de carga e descarga, são feitos de aço ou alumínio, com piso de madeira e duas portas em uma extremidade. O termo "ova" de conteiner ou "estufar" significa o procedimento de carregar, de encher o conteiner com carga, já na descarga o termo "desova" significa retirar da mercadoria transportada.

O conteiner segue um padrão internacional (padrão ISO) na largura e comprimento, para que possa ser utilizado em diferentes navios, bem como em outros modais de transportes.

A Tabela 4.1 contém as medidas padrão utilizada para o conteiner, entretanto, o comprimento mais utilizado para contêineres é: de 20 pés chamado também de TEU - Twenty Feet Equivalent Unit (6,096 metros) e os de 40 pés (12,192 metros), não variando em ambos a largura de 2,438 metros e altura de 2,591 metros.

Os contêineres de 20 pés, normalmente são utilizados para cargas mais pesadas como metais e ferros, pois, sua capacidade de peso é mais adequada. Já os contêineres de 40 pés, são mais adequados para cargas mais leves e volumosas. 
Tabela 4.1: Dados do conteiner

\begin{tabular}{|cccc|}
\multicolumn{5}{c}{ Dados do Conteiner } \\
\hline Dimensão & Largura & Altura & Comprimento \\
\hline $10^{\prime}$ & $8^{\prime}$ & 8' ou 8'6" ou 9'6" $^{\prime \prime}$ & $3,048 \mathrm{~m}$ \\
$20^{\prime}$ & $8^{\prime}$ & 8' ou 8'6" ou 9'6" & $6,096 \mathrm{~m}$ \\
$30^{\prime}$ & $8^{\prime}$ & 8' ou 8'6" ou 9'6" & $9,144 \mathrm{~m}$ \\
$40^{\prime}$ & $8^{\prime}$ & 8' ou 8'6" ou 9'6" & $12,192 \mathrm{~m}$ \\
$45^{\prime}$ & $8^{\prime}$ & 8' ou 8'6" ou 9'6" & $13,716 \mathrm{~m}$ \\
& & & \\
\hline
\end{tabular}

Fonte: sitio da International Trade Centre www.intracen.org

A utilização do conteiner para o transporte de mercadorias causou uma verdadeira revolução, de tal sorte que navios e aeronaves são construídos para sua acomodação. O seu uso intensifica-se no comércio internacional a cada dia, dando maior segurança e facilidade na movimentação e no transporte de mercadorias.

A partir da década de 1980 o custo do frete caiu de $20 \%$ para $1 \%$ do valor final da mercadoria - uma queda de $95 \%$, as exportações mundiais cresceram $500 \%$, a operação nos terminais ganhou maior agilidade, já que tornou-se mecanizada e repetitiva, diminuindo sobremaneira a utilização de mão de obra (GUANDALINO,2007).

\subsubsection{MOVIMENTAÇÃO DE CONTÊINERES}

De acordo com a Agência Nacional de Transportes Aquaviário - ANTAQ o ano de 2006 terminou com um recorde histórico registrado nos 35 portos brasileiros: 682 milhões de toneladas movimentadas. Em 2005, a marca atingida foi a de 649 milhões. O aumento das exportações e a melhoria da capacidade gerencial e os investimentos dos principais portos do país foram os principais responsáveis pelo crescimento.

Os investimentos realizados a partir de 1995, quando se iniciou o regime de privatização dos serviços portuários, ultrapassaram o valor de US\$ 435 milhões, na construção de obras físicas, aquisição de modernos equipamentos, especialização de mão-de-obra e incorporação de novas técnicas operacionais. Com isso, os terminais ampliaram, em até $400 \%$ em média, a capacidade de movimentação de contêineres nos portos 
brasileiros, comparativamente à capacidade existente no regime estatal. Estão previstos investimentos de US\$ 160 milhões até 2007.

As empresas do setor, ao adotarem padrões de administração e tecnologia em nível dos terminais internacionais, conseguiram elevar o índice de produtividade, em média, de oito contêineres por hora, anteriormente à privatização, para 45 unidades por hora, correspondendo a aumento de $460 \%$. Dados relativos ao desempenho do setor mostram que a movimentação de contêineres tem se expandido após a privatização. A movimentação total era de 1 milhão de unidades em 1994, último ano da operação portuária estatal.(SALOMÃO,2004)

O Brasil encerrou o ano de 2005 com a movimentação total de 5.937 .940 contêineres e no ano de 2006 de 6.290.253 conforme Tabela 4.2 de movimentação de contêineres no Brasil da Câmara Brasileira de Contêineres, Transporte Ferroviário e Multimodal.

Tabela 4.2: Tabela de movimentação anual de contêineres em TEUS.

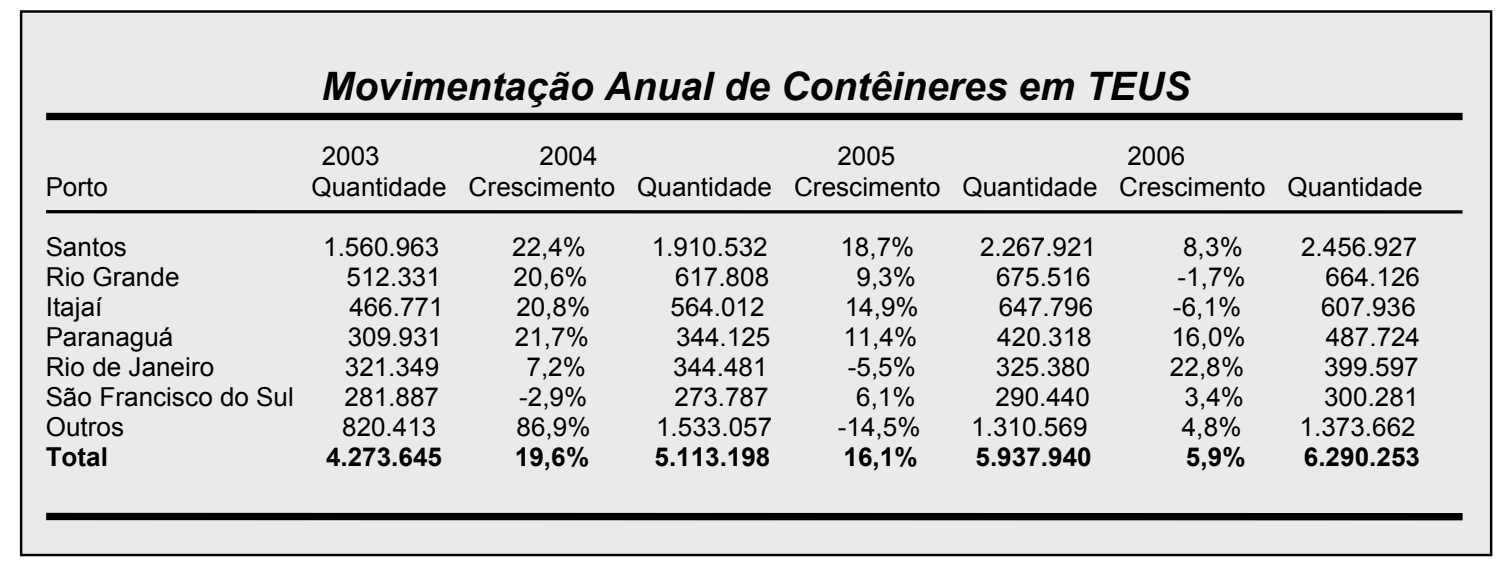

Fonte: CBC - Câmara Brasileira de Contêineres, Transporte Ferroviário e Multimodal.

A Associação Brasileira de Terminais de Contêineres, ABRATEC, calcula, com base no crescimento verificado durante os primeiros nove meses de 2006, uma movimentação de 1,7 milhão de unidades movimentadas apenas no porto de Santos - o porto onde mais se concentrou a movimentação de contêineres no país. Em 2006 o segundo porto que mais movimentou contêineres no país foi o de Itajaí, com 390 mil unidades, seguido do Porto de Rio Grande, com 387 mil unidades. 
Conforme dados do porto de Santos, a carga geral conteinerizada totalizou em 2006, 1.603 .868 contêineres, equivalente a 2.456.927 teus (unidade equivalente a um contêiner de 20 pés), representando 24,787 mil t de cargas. Para 2007 a expectativa dos terminais é um incremento entre 5 e 13\%. Já a o porto de Santos projeta um crescimento mais conservador, em torno de $5,7 \%$ ou 1,648 milhão $t$.

Tabela 4.3: Tabela de movimentação de contêineres no porto de Santos.

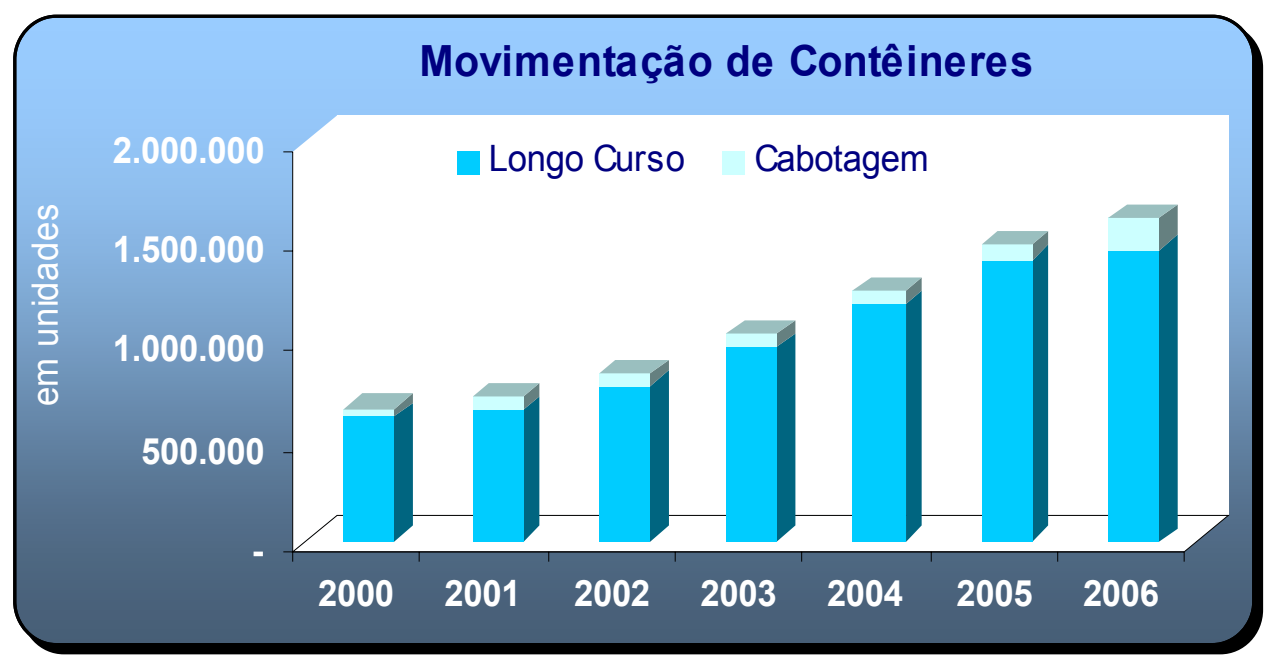

Fonte: Porto de Santos.

\subsubsection{INICIATIVA DE SEGURANÇA DO CONTEINER (SCI)}

Esta iniciativa adapta-se na estratégia das Nações Unidades de impedir o aumento de armas de destruição em massa (Weapons of Mass Destruction - WMD). Materializa na intenção de um conjunto de países em se empenharem em combater a proliferação de Armas de Destruição Maciça - ADM, limitando as oportunidades aos traficantes.

A segurança global implica, necessariamente, numa atuação determinada de todos os que têm responsabilidades no âmbito das regras vigentes e do direito Internacional, sem negar nem criar limitações a quem opera estes materiais para fins pacíficos ou dentro da legalidade.

A Iniciativa de Segurança do Conteiner, "Container Security Initiative - (CSI)" é um plano estratégico desenvolvido pela "U.S. Customs and Border Protection (CBP)" 
em janeiro de 2002, o CSI propõe um regime de segurança para assegurar que todos os contêineres que apresentem um risco potencial do terrorismo sejam identificados e inspecionados em portos estrangeiros antes que eles sejam colocados em navios destinados aos Estados Unidos.

A Iniciativa de Segurança de Conteiner é um programa revolucionário para estender a nossa zona da segurança protegendo contêineres os quais apresentem potencial risco de segurança antes que os mesmos partam de portos estrangeiros para os Estados Unidos. A nossa meta deve processar 85 por cento de todos os contêineres que venham se dirigir aos Estados Unidos por portos CSI antes de 2007. (Bashan, 2007, tradução nossa) ${ }^{14}$

O programa de Segurança do Conteiner - SCl contou com duas fases:

Fase l: apontou os 20 portos com maior volume de exportações para os EUA (nenhum da América Latina ou do Caribe).

Fase II: (em andamento) focada em portos que exportam níveis significativos de carga aos EUA.

Para a integração dos portos da CSI existe um conjunto de requisitos a que os mesmos devem obedecer entre os quais podem ser referidos os seguintes:

a) A assinatura de uma Declaração de Princípios entre as Alfândegas americanas e as do país onde se situa o porto a integrar, na qual se estabelece o aprofundamento da cooperação e assistência mútua bilateral em matéria aduaneira;

b) O porto a integrar deve ter um movimento significativo de contêineres destinados a portos americanos;

c) A existência no porto de um equipamento de controle não-intrusivo (denominado scanner) de modo a permitir, de forma rápida e sem criar obstáculos ao fluxo regular do comércio internacional, o rastreio do conteúdo dos contêineres, permitindo direcionar controles aprofundados para aqueles

\footnotetext{
${ }^{14}$ Palavras do comissário da aduana americana (CBP) Sr. W. Ralph Basham, na abertura da conferência da Associação Americana de Exportadores e Importadores sobre o plano Estratégico da CSI para 2006-2011, sediada em Nova York, 08/2006.
} 
sobre os quais existem indícios de tráficos ilícitos, designadamente de armas de destruição maciça.

$\mathrm{Na}$ Tabela abaixo está relacionado 50 portos CSI com suas respectivas data de aprovação são:

Tabela 4.4: Portos com Iniciativa de Segurança do Conteiner (SCI)

\begin{tabular}{|c|c|c|c|c|c|}
\hline Países Asiáticos & Portos & Datas & $\begin{array}{l}\text { Paises } \\
\text { Europeus }\end{array}$ & Portos & Datas \\
\hline China & Shanghai & $28 / 04 / 2005$ & Bélgica & Antwerp & $23 / 02 / 2003$ \\
\hline & Shenzen & $24 / 06 / 2005$ & & Zeebrugge & $29 / 10 / 2004$ \\
\hline & Kaohsiung & $25 / 07 / 2005$ & França & Le Harve & $02 / 12 / 2002$ \\
\hline & Hong Kong & $05 / 05 / 2003$ & & Marseille & $07 / 01 / 2005$ \\
\hline Tailândia & $\begin{array}{l}\text { Laem } \\
\text { Chabang }\end{array}$ & $13 / 08 / 2004$ & Alemanha & Bremerhaven & $02 / 02 / 2003$ \\
\hline Sri Lanka & Colombo & $29 / 09 / 2005$ & & Hamburg & $09 / 02 / 2003$ \\
\hline Malásia & Port Klang & $08 / 03 / 2004$ & Grécia & Piraeus & $27 / 07 / 2004$ \\
\hline & $\begin{array}{l}\text { Tanjung } \\
\text { Pelepas }\end{array}$ & $16 / 08 / 2004$ & Itália & Genoa & $16 / 06 / 2003$ \\
\hline Japão & Yokohama & $24 / 03 / 2003$ & & La Spezia & $23 / 06 / 2003$ \\
\hline & Tokyo & $21 / 05 / 2004$ & & Livorno & $30 / 12 / 2004$ \\
\hline & Kobe & $06 / 08 / 2004$ & & Naples & $30 / 09 / 2004$ \\
\hline & Nagoya & $06 / 08 / 2004$ & & Gioia Tauro & $31 / 10 / 2004$ \\
\hline Korea & Pusan & $04 / 08 / 2003$ & Holanda & Rotterdam & $02 / 09 / 2002$ \\
\hline Singapura & Singapore & $10 / 03 / 2003$ & Espanha & Algeciras & $30 / 07 / 2004$ \\
\hline Emirados Árabes & Dubai & $26 / 03 / 2005$ & & Barcelona & $25 / 09 / 2006$ \\
\hline Oman & Port Salalah & $08 / 03 / 2006$ & & Valencia & $25 / 09 / 2006$ \\
\hline Taiwan & Chi-Lung & $25 / 09 / 2006$ & Suíça & Gothenburg & $23 / 05 / 2003$ \\
\hline $\begin{array}{l}\text { Paises } \\
\text { Americanos }\end{array}$ & Portos & Datas & Inglaterra & Fellxstowe & $24 / 05 / 2003$ \\
\hline Canadá & Halifax & $02 / 03 / 2003$ & & Southhampton & $01 / 11 / 2004$ \\
\hline & Montreal & $02 / 03 / 2003$ & & Liverpool & $01 / 11 / 2004$ \\
\hline & Vancouver & $02 / 03 / 2003$ & & Thamesport & $01 / 11 / 2004$ \\
\hline Brasil & Santos & $22 / 09 / 2005$ & & Tillbury & $01 / 11 / 2004$ \\
\hline Argentina & Buenos Aires & $17 / 11 / 2005$ & Portugal & Lisbon & $14 / 12 / 2005$ \\
\hline Honduras & Puerto Cortes & $25 / 03 / 2006$ & Pais Africano & Porto & Data \\
\hline Jamaica & Kingston & $28 / 09 / 2006$ & África do Sul & Durban & $01 / 12 / 2003$ \\
\hline $\begin{array}{l}\text { República } \\
\text { Dominicana }\end{array}$ & Caucedo & $25 / 09 / 2006$ & \multirow{2}{*}{\multicolumn{3}{|c|}{ 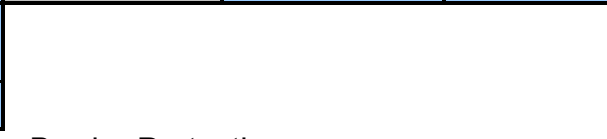 }} \\
\hline Bahamas & Freeport & $30 / 09 / 2006$ & & & \\
\hline
\end{tabular}

Fonte: U.S. Customs as Border Protection

Face ao volume de contêineres e o fato de ter linhas de transporte marítimo direta para portos americanos, o porto de Santos, a nível nacional, tornou-se o $39^{\circ}$ porto CSI em 22 de setembro de 2005, pois reúne condições para integrar a CSI com expedição de cerca de 106.496 contêineres em 2006 para portos americanos.

Com essa ação, o porto de Santos passou a ser o primeiro da América do Sul a participar dessa experiência, que é feita em 50 portos do mundo, com base no 
programa CSI, que prevê medidas para dar maior segurança às cargas transportadas, de um destino ao outro.

Finalmente é de realçar que, com a integração do porto de Santos na CSI, almeja-se alcançar diversos objetivos, entre os quais:

a) O da elevação dos níveis de controle da segurança dos cidadãos e da cadeia logística do comércio internacional, designadamente do porto, dos navios, dos contêineres e das mercadorias nelas transportadas;

b) A modernização do porto, passando a ser utilizadas modernas tecnologias de controle, fixando-se, concretamente, linhas de transporte marítimo diretas para os portos americanos;

c) Maior eficácia dos controles aduaneiros e fiscais e no combate à fraude aduaneira e fiscal e a todos os tráficos ilícitos;

d) A proteção da economia nacional, uma vez que as empresas exportadoras, a não se concretizar a integração, poderiam estar sujeitas a que os contêineres que transportam as suas mercadorias terem de ser controlados em outros portos intermediários ou mesmo terem de ser desviados dos portos a que se destinavam para serem controlados em portos secundários americanos. Qualquer uma dessas hipóteses traduziria num retardamento dos prazos de entrega aos destinatários e numa elevação dos custos, diminuindo-lhes competitividade e capacidade de concorrência. 


\section{SISTEMA SE SEGURANÇA PÚBLICA PORTUÁRIA NO PORTO DE SANTOS}

O porto de Santos administrado pela Companhia Docas do Estado de São Paulo - CODESP, maior porto da América do Sul encerrou o ano de 2006 totalizando $76,297 \mathrm{t}$ mil de cargas movimentadas, registrando um incremento na ordem de $6,1 \%$ sobre 2005 . O aumento foi determinado pelo crescimento de $11,3 \%$ no movimento de líquidos a granel; $8,5 \%$ na carga conteinerizada, respondeu pelo transporte de $26,4 \%$ da balança comercial correspondendo a US\$ 60,4 bilhões representando $6,3 \%$ do PIB.

Possui na margem Direita $3,6 \mathrm{~km}$, margem esquerda $4,1 \mathrm{~km}$ e sua extensão por metro linear é de 13.013 , com 54 berços CODESP e 10 privativos com profundidades variando de 5,0m e 13,5m, localizado apenas $65 \mathrm{~km}$ de São Paulo, maior cidade brasileira, conta de um grande complexo de transporte, e num raio de $100 \mathrm{~km}$, dois aeroportos internacionais complementam sua intermodalidade.

Em maio de 2004 quando o Governo Federal liberou a verba para que os portos se adequassem ao código de segurança, a CODESP, dentro da seqüência de procedimentos do código, teve sua "Avaliação de Riscos" aprovada na primeira semana de fevereiro de 2004 e seu "Plano de Segurança" na última de junho do mesmo ano.

Em agosto de 2007 já estavam aptos, com o TA ou DC, 45 terminais do porto de Santos a operar sob o novo código.

O porto de Santos, na primeira etapa, teve a responsabilidade de instalar:

- Construção de 28 Gates;

- Construção do Centro de Controle e de Comunicação (CCCOM);

- Melhorias na lluminação pública;

- Melhorias ou construção de muros e cercas;

- Aquisição e instalação de câmeras de vigilância, torniquetes, handkeys, catracas, computadores e periféricos;

- Construção de laje sobre o canal 4 (Avenida Siqueira Campos);

- Montagem do CCCOM;

- Montagem do Centro de Cadastramento; 
- Integração de todos os Subsistemas de Imagem, de Comunicação e de Controle de Acesso;

- Integração geral com os Arrendatários e Autoridades Públicas e

- Normatização e Treinamento.

Segunda etapa, a desenvolver:

- Implantação do controle das áreas de canal e fundeadouro, através de VTMIS;

- Contratação da manutenção do Sistema de Segurança Pública Portuária inicializado em junho de 2007; e

- Implantação de novas câmeras fixas para o monitoramento da interface cais/navio.

Terceira etapa, a desenvolver:

- Construção da torre de monitoramento; contendo o VTMIS bem como o novo centro de controle, tornando o CCCOM como contingência;

- Transferência total de tecnologia;

- Fornecimento e instalação de um subsistema de controle de acesso ao edifício da presidência;

- Projeto e fornecimento e instalação de um conjunto motor gerador;

- Projeto executivo de sistema de telefonia IP (Internet Protocol);

- Projeto executivo de radio comunicação digital, integrado on-line com sistema de CFTV existente;

- Fornecimento de um novo backbone ${ }^{15}$ para contingência ao existente com tecnologia wireless (tecnologia de rede sem fios);

- Fornecimento e instalação de insumos, equipamentos e obras complementares de melhorias dos Gates; e

- Fornecimento e instalação de painéis de mensagens variáveis.

\footnotetext{
${ }^{15}$ No contexto de redes de computadores, o backbone (traduzindo para português, espinha dorsal) designa o esquema de ligações centrais de um sistema mais amplo, tipicamente de elevado débito relativamente à periferia.
} 


\subsection{MODELO ATUAL}

O Sistema de Segurança Pública Portuária - SSPP do porto de Santos contou com o apoio e colaboração da Fundação de Apoio à Universidade de São Paulo (FUSP) por meio do Departamento de Energia e Automação Elétricas, o qual já vem trabalhando no porto de Santos desde 1990.

A FUSP integrou os dois subsistemas de Controle de Acesso e Circuito Fechado de TV - CFTV das três empresas fornecedoras de tecnologias.

Para esta integração a FUSP utilizou o protocolo OPC (OLE Process Control) que faz a padronização das interfaces de comunicação entre os servidores e clientes de dados em tempo real, facilitando a integração e manutenção dos sistemas, eliminando a necessidade de drivers de comunicação específicos (proprietários), contribuindo para a melhoria do desempenho e otimização da comunicação entre os dispositivos de automação.

O SSPP foi desenvolvido para acompanhar as atividades desenvolvidas pelas CESPORTOS na promoção, em âmbito regional, da troca de informações e experiências, bem como na aplicação de planejamento integrado e na coordenação de ações de segurança pública de interesses comuns. Estará funcionalmente preparado para:

- Identificar, controlar e gerenciar o acesso de pessoas e veículos utilizando processos de automação e equipamentos adequados;

- Controlar a movimentação de cargas através da integração da solução de controle de acesso de pessoas e veículos com os sistemas existentes e operantes na CODESP, e em sintonia com a Alfândega de Santos, haja vista o porto ser hoje um Porto CSI - Container Security Initiative, e por isso será dotado de scanners fixos e móveis (instalação a cargo da Receita Federal), além de ter sido o porto escolhido como piloto para a implantação do chamado PNSA, ou seja, Plano Nacional de Segurança Aduaneira, da mesma Receita Federal;

- Integrar no Centro de Controle e de Comunicação - CCCOM da CODESP, as informações de todos os sistemas que compõem o SSPP com a Supervia Eletrônica de Dados (SED) descrito no Item 5.2; 
- Integrar o porto e seus terminais com as demais autoridades externas, tais como: Ministério da Justiça, Ministério dos Transportes, Departamento de Polícia Federal (DPF), Departamento de Polícia Rodoviária Federal (DPRF), Marinha do Brasil, Receita Federal, Secretaria de Estado da Segurança

Pública de São Paulo, INFOSEG - Sistema de Informações de Justiça e Segurança Pública e INFOCRIM - Sistemas de Informações Criminais;

- Prover conjunto de informações gerenciais à Autoridade Portuária, Terminais, Guarda Portuária e Delegacia de Policiamento Marítimo, para que sejam geradas ações preventivas de Segurança Pública Portuária dentro do porto, dos terminais, áreas de fundeio, canal de acesso, vias rodoviárias e ferroviárias do porto;

- Gerar dados e informações estatísticas que auxiliarão a CODESP, Terminais e demais organismos externos a promoverem ações de melhorias no processo logístico e de infra-estrutura do porto organizado de Santos.

Nessa primeira etapa do SSPP, estarão funcionando, para atender as premissas básicas, cinco novos subsistemas que serão detalhados a seguir, devidamente centralizados operacionalmente no CCCOM:

- Subsistema de Comunicação;

- Subsistema de Cadastramento e Credenciamento de Usuários;

- Subsistema de Controle de acesso;

- Subsistema de Circuito Fechado de TV (CFTV);

- Subsistema Gestor de Eventos.

\subsection{SISTEMA SUPERVIA ELETRÔNICA DE DADOS (SED)}

O Sistema Supervia Eletrônica de Dados - SED consiste na captação de informações gerenciais por meio EDI (Eletronic Data Interchange), do serviço de VAN (Value Added Network) e internet. Trata-se de um sistema desenvolvido para atender as pessoas jurídicas ligadas à comunidade de Atividade Portuária 
disponibilizando a troca de informação 24 horas por dia, sete dias por semana. Através dele a comunidade envia e recebe informações sobre atracação e desatracação de navios, a movimentação de carga e a liberação de cargas junto a autoridade aduaneira sem a necessidade de sair da sua empresa, simplificando e otimizando seus processos e controles, reduzindo custos operacionais. Proporciona também mecanismos de maior controle dos diferentes processos, redução na probabilidade de erros, redução no fluxo de papéis, e acompanhamento de cláusulas contratuais referentes aos contratos de arrendamento de área a serem rigorosamente cumpridas por partes dos arrendatários. Permitindo ainda a fiscalização do fluxo das embarcações e mercadorias nas duas correntes (importação e exportação) de operação de descarga e embarque, que sejam de responsabilidade dos operadores portuários.

A SED teve seu primeiro módulo RAP (Prioridade e Requisição de Atracação) implantação em 23 de abril de 2001, os demais módulos como Manifesto de Navios e Boletins de Carga e Descarga implantados em janeiro de 2004.

A SED recepciona os dados relativos aos seguintes módulos:

- Atracação;

- Manifesto de Carga;

- Boletim de Embarque /Descarga.

Todos os navios, abrangidos pelo Código ISPS, que pretendam entrar no porto de Santos deverão prestar à Autoridade Portuária via SED informações sobre a Livre Prática e número do certificado ISPS Code do navio.

Também via SED será feito o envio dos arquivos de dados para o credenciamento de usuários às áreas restritas do porto de santos, esta integração é vista no item 5.8 desta dissertação.

\subsection{SUBSISTEMA DE COMUNICAÇÃO.}

O backbone utilizado para a transmissão digital do sinal eletrônico é composto por uma rede principal com velocidade de transmissão de 1 GB, via fibra 
óptica entre os transmissores e receptores opto-eletrônicos dos Gates e Centro de Controle e Comunicação (CCCOM) representado na Figura 4.

Os Gates estão distribuídos na área do porto de Santos em duas margens direita e esquerda e estão identificados nas figuras dos ANEXOS E, F e G conforme numeração a seguir.

Margem direita - Santos:

- Gate 01 - Acesso à Administração da Petrobrás - Alemoa

- Gate 02 - Acesso á Alemoa

- Gate 03 - Acesso aos Píeres da Alemoa

- Gate 04 - Acesso a Deicmar e Píer do Saboó

- Gate 05 - Rodrimar

- Gate 06 - Píer dos armazéns 10/11

- Gate 07 - Píer na DIROP

- Gate 08 - VCP

- Gate 09 - Teaçu

- Gate 10 - Copersucar

- Gate 11 - Concais

- Gate 12 - T-Grão

- Gate 13 - Canal 4

- Gate 14 - Citrosuco/NST - Píer

- Gate 15 - CBA TEAG - Píer

- Gate 16 - Libra 35

- Gate 17 - TEAG - Píer

- Gate 18 - Libra 37

- Gate 19 - Macuco

- Gate 20 - Corredor de Exportação

- Gate 21 - Acesso ao cais da Libra 37

- Gate 22 - ADM

- Gate 23 - Acesso a Presidência

- Gate 24 - Saída da Presidência

- Gate 25 - Entrada/Saída das oficinas - área da Presidência 
Margem esquerda - Guarujá:

- Gate 26 - Acesso por terra à llha Barnabé

- Gate 27 - Acesso aos Píeres da llha Barnabé

- Gate 28 - Acesso por mar à llha Barnabé.

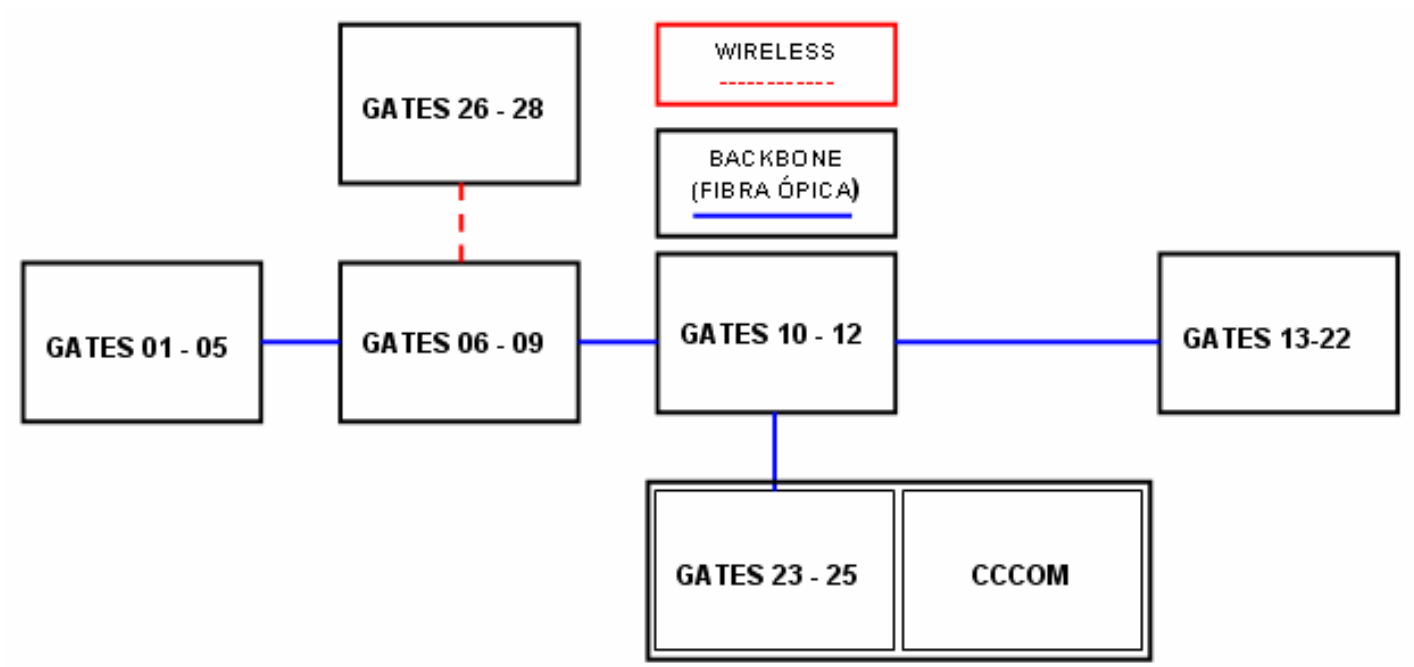

Figura 5: Fluxo de comunicação dos Gates.

A tecnologia utilizada pela CODESP para fazer a comunicação entre os Gates e o CCCOM é Voice Over IP (VoIP) ou Voz Sobre IP tornando possível estabelecer conversações telefônicas na Rede IP, tornando a transmissão de voz mais um dos serviços suportados pela rede de dados.

A comunicação telefônica via VoIP apresenta grandes vantagens sobre a telefonia convencional, sendo que a principal delas tem sido a redução de despesas que proporciona, visto que a rede de dados (e consequentemente a VoIP) não está sujeita à mesma tarifação das ligações telefônicas convencionais, que é calculada em função de distâncias geodésicas e horários de utilização estabelecidos pelas Operadoras de Telefonia. Outra grande vantagem da VoIP em relação à telefonia convencional é que esta última está baseada em comutação de circuitos, que podem ou não ser utilizados, enquanto a VoIP utiliza comutação por pacotes, o que a torna mais "inteligente" no aproveitamento dos recursos existentes (circuitos físicos e largura de banda). Esta característica (comutação por pacotes) também traz outra vantagem a VolP, que é a capacidade dos pacotes de voz "buscarem" o melhor caminho entre dois pontos, tendo sempre mais de um caminho, ou rota, disponível e, portanto, com maiores opções de contingência (característica intrínseca das redes IP). 
VolP geralmente é tratada em algumas ocasiões como sendo o mesmo que Telefonia IP embora sejam definições totalmente distintas. VolP é a tecnologia ou técnica de se transformar a voz no modo convencional em pacotes IP para ser transmitida por uma rede de dados, enquanto a Telefonia IP, que utiliza VoIP, traz consigo um conceito de serviços agregados muito mais amplo, já que carrega outras aplicações que não somente VoIP.

A Telefonia IP permite a redução dos custos de telefonia das empresas, pois convergem serviços de dados, voz, fax e vídeo, e também constrói novas infraestruturas para aplicações avançadas de e-commerce (ex., Call center Web).

Cada host TCP/IP (qualquer sistema conectado a uma rede TCP/IP, não importa a sua natureza, é chamado, genericamente, um host) é identificado por um endereço IP lógico. Esse endereço é exclusivo para cada host que se comunica usando TCP/IP. Cada endereço IP de 32 bits identifica um local de um sistema host na rede da mesma forma que um endereço residencial identifica uma casa em uma rua da cidade.

Assim como um endereço residencial tem um formato padrão composto de duas partes (nome da rua e número do domicílio), cada endereço IP é separado internamente em duas partes - uma identificação de rede e um identificador de host.

Todos os dispositivos e equipamentos de controle de acesso (leitoras das catracas, torniquetes, cancelas) e Circuito Fechado de TV (câmeras fixas e móveis) são constituídos por um endereçamento IP.

A identificação de rede, também conhecida como endereço de rede, identifica um único segmento de rede em um conjunto de redes TCP/IP. Todos os sistemas que se conectam e compartilham o acesso à mesma rede têm uma identificação de rede comum no seu endereço IP completo. Essa identificação também é usada para identificar de forma exclusiva cada rede dentro do conjunto maior de redes.

O identificador de host, também conhecido como endereço de host, identifica um nó TCP/IP (uma estação de trabalho, um servidor, roteador ou outro dispositivo $\mathrm{TCP} / \mathrm{IP}$ ) em cada rede. O identificador de host de cada dispositivo identifica de forma exclusiva um sistema em sua própria rede.

Na margem esquerda, no Terminal de Conteiner - Tecon e Conceiçãozinha, foram instaladas câmeras fixas e móveis para o subsistema de CFTV. A 
comunicação desta região com a CCCom tem transmissão de sinal de vídeo via wireless.

Para a comunicação das outras regiões (Valongo, Deicmar, Alemoa e llha Barnabé) com a Central de Controle e Comunicação da CODESP foi criado um backbone de rede ethemet (é uma tecnologia de interconexão para redes locais) baseado em fibra ótica e de tecnologia de rede sem fios - wireless. A tecnologia wireless é utilizada para criação de um enlace de rádio para comunicação da Ilha Barnabé com a margem direita. Foram realizadas análises mais detalhadas e testes de "site-survey" 16 para identificação dos melhores posicionamentos para as antenas do link de rádio, tanto para a que se localiza na llha Barnabé (Torre) quanto para a que se localiza na margem direita (antena da Alfândega).

\section{Foto Porto de Santos

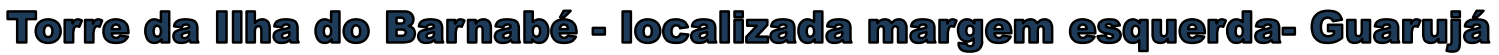

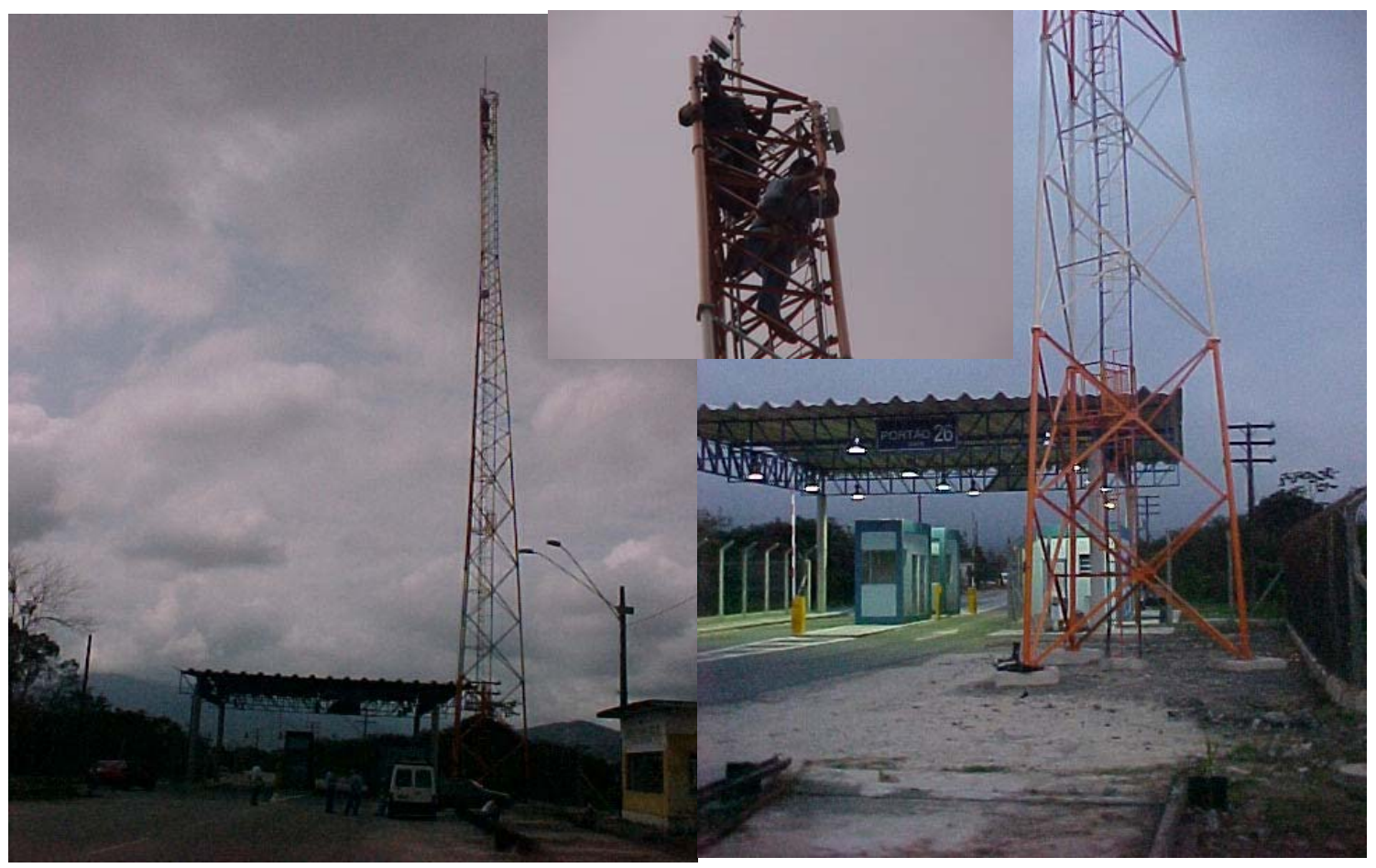

Figura 6: Sistema wireless para rádio de comunicação de dados, vídeos e VolP.

\footnotetext{
16“site survey" é uma metodologia aplicada na inspeção técnica minuciosa do local que será objeto da instalação de uma nova infra-estrutura de rede, na avaliação dos resultados obtidos com as melhorias da infra-estrutura existente ou mesmo na identificação e solução dos problemas de um sistema já em funcionamento.
} 


\subsection{SUBSISTEMA DE CADASTRAMENTO E CREDENCIAMENTO DE USUÁRIOS}

Sistema de cadastramento e credenciamento de usuários do porto que estabelece uma hierarquia de acesso conforme o perfil dos usuários que permitirá o acesso ao Gates controlados eletronicamente pelo SSPP.

Com este modelo de cadastramento e crachá eletrônico utilizado pela CODESP impedirá que usuários, como o OGMO ou outros, tenham acesso ao cais sem sua identificação biométrica, o que acabaria com os tradicionais "cavalos", que são indivíduos que trabalham esporadicamente usando a documentação de outras pessoas.

\subsubsection{MÓDULO IDENTIFICAÇÃO DO RESPONSÁVEL}

As empresas identificadas como Responsáveis pela Autoridade Portuária deverão comparecer ao setor de cadastramento de Responsável na CODESP, em posse dos documentos exigidos para habilitação ANEXO H, para fins de validação de seu cadastramento para ter acesso às áreas restritas no SSPP.

Uma vez homologado pela CODESP, o Responsável estará apto a solicitar cadastramento e acesso de Usuários (pessoas e veículos) às áreas restritas do porto que poderá ser feita pelo preenchimento de ficha cadastral no site http://www.ispssantos.com.br/ da Associação Profissional dos Usuários dos Portos de São Paulo (APUPESP), ou através do envio de arquivo de dados correspondente, serviço esse, que estará disponível pela SED. Para uso do site da SED, http://www.superviadedados.com.br/, são necessárias à utilização de login e senha de acesso, os quais serão fornecidos pela CODESP.

O Responsável deverá autorizar uma ou mais pessoas a receber os logins e senhas, dados esses que estarão vinculados ao Cadastro de Pessoa Física - CPF da pessoa correspondente. Todo acesso e toda operação efetuada no site serão registrados pelo SSPP, por CPF. O fluxograma genérico referente ao cadastramento de Responsável é apresentado na Figura 7. 


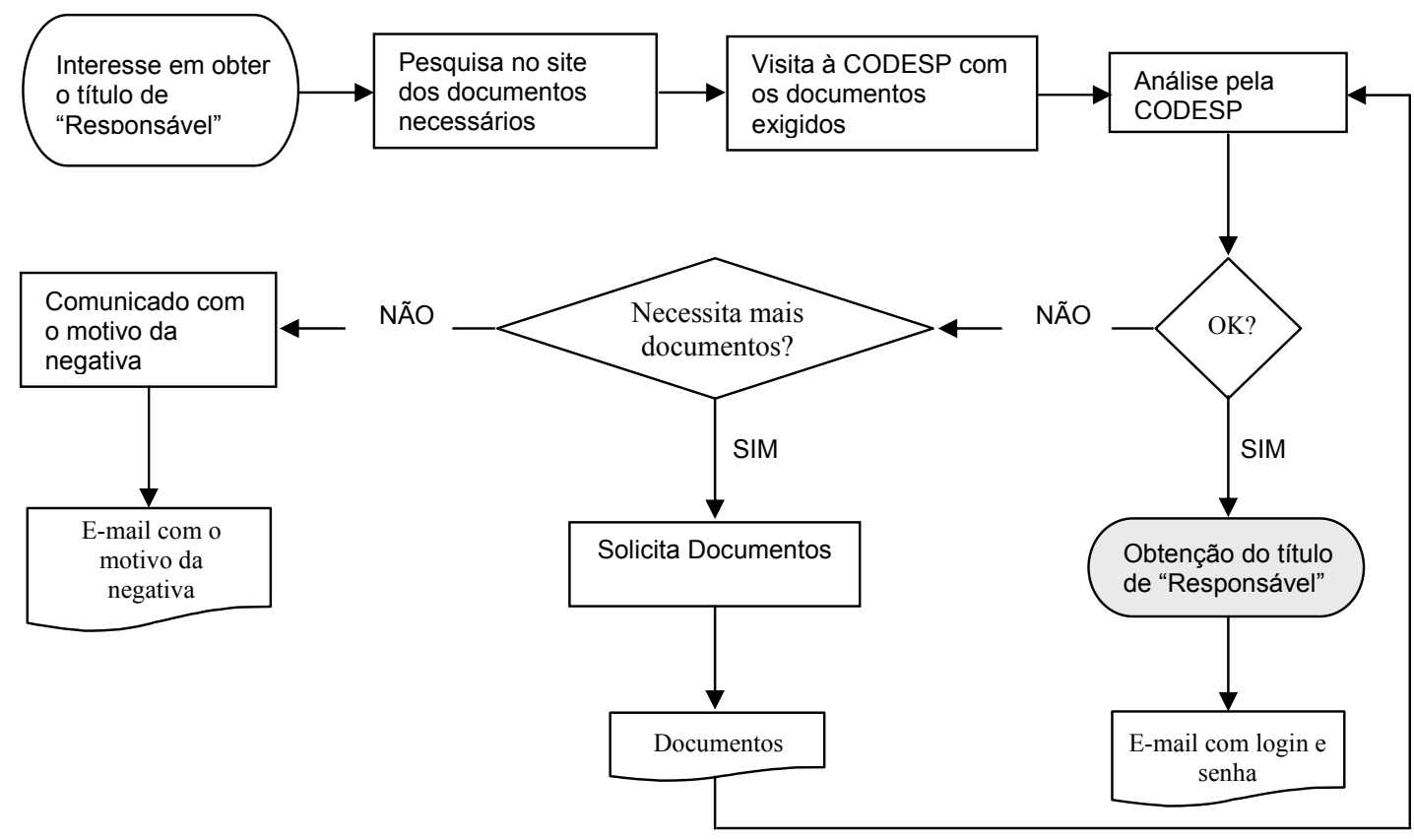

Figura 7: Fluxograma do Cadastramento de Responsável

\subsubsection{MÓDULO IDENTIFICAÇÃO DO USUÁRIO}

O Responsável deverá identificar e registrar os dados de um usuário (pessoa ou veículo) no SSPP para posteriormente solicitar seu acesso às áreas restritas do porto, bem como o(s) Gate(s) de acesso.

$\mathrm{Na}$ fase inicial de implantação do cadastramento, o Usuário que já possuir crachá expedido pela Alfândega, desde que o mesmo esteja no período de validade e não apresente rasuras que indiquem violação ou falsificação, deverá solicitar a troca deste para um novo junto a CODESP.

A CODESP é a única entidade responsável para expedir os crachás de acesso, conforme fluxo específico aplicado ao perfil do usuário.

Como mencionado anteriormente, o cadastramento de Usuário poderá ser feito pelo preenchimento de ficha cadastral no site do SSPP ou pelo envio de arquivo de dados correspondente (detalhes no item 5.8.).

Genericamente, o processo de cadastramento de Usuário segue o fluxograma apresentado na Figura 8. 


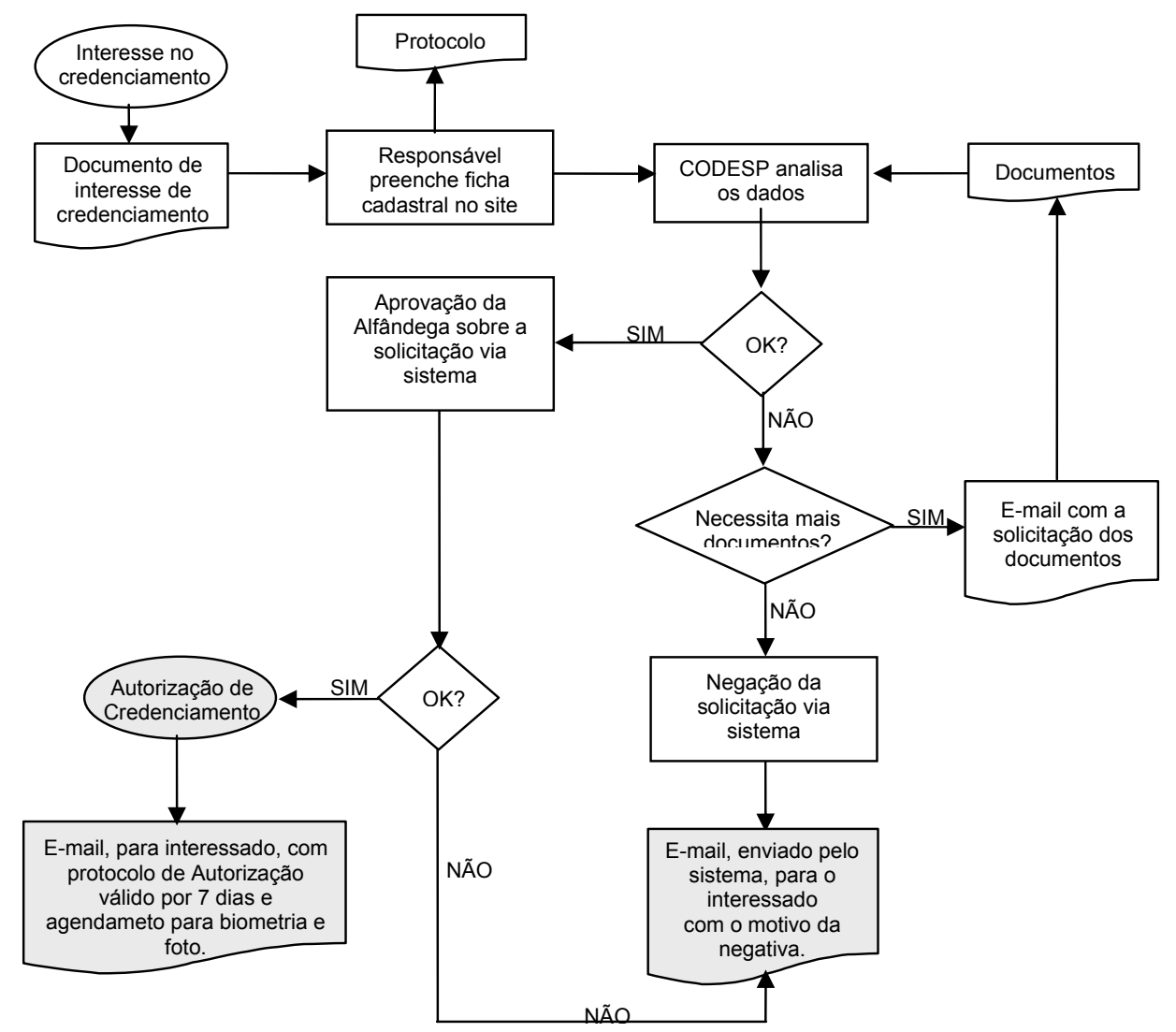

Figura 8: Fluxograma do Cadastramento de Usuários

"Os processos de cadastramento e emissão de crachás para cada perfil de usuário são:

a) Visitantes:

O Responsável receberá um lote de crachás destinados a visitantes.

- O Responsável cadastra os dados do visitante e, quando for o caso, de seu veículo bem como o número do crachá que o visitante irá utilizar e o número do crachá do acompanhante da visita (funcionário ou representante do responsável) através do site do SSPP ou através do envio de arquivo de dados via SED, solicitando, assim, autorização de acesso às áreas restritas do porto;

- A autorização se dará de forma automática, caso não haja impedimentos para isso, e ao visitante serão concedidos os mesmos direitos de acesso que o acompanhante possui, ou seja, a área em que o acompanhante tiver acesso, o visitante o terá também. 
- Estas informações ficam disponíveis para consulta pela Alfândega e Polícia Federal, que podem, a qualquer tempo, solicitar o bloqueio do crachá do visitante, fato esse informado em seguida ao Responsável.

Ficará a critério do dono do crachá, no caso o Responsável, o local e a forma de devolução do mesmo após sua devida utilização.

b) Funcionários CODESP, Funcionários Alfândega, Funcionários de demais autoridades, Diretoria CODESP:

- A Autoridade cadastra os dados do funcionário e, quando for o caso, de seu veículo através do site do SSPP ou através do envio de arquivo de dados via SED, solicitando, assim, seu credenciamento para acesso às áreas restritas do porto;

- A CODESP analisa os dados recebidos e autoriza o credenciamento, caso não haja impedimentos para isso. Em seguida, a CODESP faz a convocação do funcionário, agendando comparecimento ao setor de credenciamento, onde mediante apresentação de documento, serão registradas a biometria e a foto, concedendo, assim, seu acesso conforme local(ais) e período(s) desejados;

- A CODESP emite o(s) crachá(s) e os entrega ao funcionário;

- Estas informações ficam disponíveis para consulta pela Alfândega e Polícia Federal, que podem, a qualquer tempo, solicitar o bloqueio do crachá do visitante, funcionário ou seu descredenciamento, fatos esses informados em seguida à Autoridade Responsável pelo cadastramento do funcionário.

c) Prestadores Serviços CODESP e Prestadores de serviços Alfândega:

- O Responsável cadastra os dados de seu funcionário e, quando for o caso, de seu veículo através do site do SSPP ou através do envio de arquivo de dados via SED, solicitando, assim, seu credenciamento para acesso às áreas restritas do porto; 
- A CODESP analisa os dados recebidos e informa à Alfândega a respeito da solicitação, dependendo do local de trabalho;

- A CODESP autoriza o credenciamento, caso não haja impedimentos para isso, e faz a convocação do funcionário, agendando comparecimento ao setor de credenciamento, onde mediante apresentação de documento, serão registradas a biometria e a foto, concedendo, assim, seu acesso conforme local (ais) e período desejados;

- A CODESP emite o(s) crachá(s) e os entrega ao funcionário;

- Estas informações ficam disponíveis para consulta pela Alfândega e Policia Federal, que podem, a qualquer tempo, solicitar o bloqueio do crachá do funcionário ou seu descredenciamento, fatos esses informados em seguida ao Responsável.

d) Prestadores de Serviços do Porto, Funcionário OGMO, Funcionários do Serviço de Praticagem, Imprensa, Funcionários de Sindicato:

- O Responsável cadastra os dados de seu funcionário e, quando for o caso, de seu veículo e/ou equipamentos através do site do SSPP ou através do envio de arquivo de dados via SED, solicitando, assim, seu credenciamento para acesso às áreas restritas do porto;

- A CODESP analisa os dados recebidos e autoriza o credenciamento do funcionário e, quando for o caso, de seu veículo, caso não haja impedimentos para isso, e informa à Alfândega a respeito;

- A Alfândega autoriza a solicitação, caso não haja impedimentos para isso;

- Em seguida, a CODESP faz a convocação do funcionário, agendando o comparecimento ao setor de credenciamento, onde mediante apresentação de documento, serão registradas a biometria e a foto, concedendo, assim, seu acesso conforme local(ais) desejados;

- A CODESP emite o(s) crachá(s) e os entrega ao funcionário;

- Estas informações ficam disponíveis para consulta pela Alfândega e Policia Federal, que podem, a qualquer tempo, solicitar o bloqueio do crachá do funcionário ou seu descredenciamento, fatos esses informados em seguida ao Responsável. 
e) Trabalhadores Portuários Avulsos (TPA):

- O OGMO envia arquivo de dados via SED para fins de: cadastramento dos TPA sem credenciamento, solicitação para emissão de $2^{\mathrm{a}}$ via de crachá para TPA ou atualização de cadastro dos TPA;

- A CODESP analisa os dados recebidos e autoriza o credenciamento, a emissão de $2^{a}$ via de crachá ou a atualização de cadastro dos TPA, caso não haja impedimentos para isso. Em seguida, a CODESP faz a convocação dos TPA, agendando comparecimento ao setor de credenciamento, onde mediante apresentação de documento, serão registradas a biometria e a foto;

- A CODESP emite o crachá, quando for o caso, e o entrega ao TPA;

- O OGMO é quem gravará no crachá do TPA o período e o local de trabalho conforme definidos na escala. Assim que finalizado o período de trabalho do TPA e registrada a sua saída da zona primária, o crachá do TPA ficará desativado temporariamente até que uma nova ativação seja feita pelo OGMO quando de sua escala para um novo período de trabalho;

- Estas informações ficam disponíveis para consulta pela Alfândega e Policia Federal, que podem, a qualquer tempo, solicitar o bloqueio do crachá do TPA ou seu descredenciamento, fatos esses informados em seguida ao OGMO.

f) Tripulantes:

O Agente Marítimo, representante do Armador, deverá adquirir crachás de acesso em seu nome para tripulantes (que estiverem a bordo de navios de carga). Este módulo quando implantado atenderá o perfil desse usuário.

- O Agente Marítimo cadastra os dados do tripulante bem como os dados do crachá que o mesmo irá utilizar na página da Atracação localizada no site da Supervia Eletrônica de Dados, 48 horas antes da reunião;

- A CODESP analisa os dados recebidos e autoriza a vinculação do tripulante aos crachás, caso não haja impedimentos para isso, e informa à Polícia Federal a respeito; 
- A Polícia Federal faz a sua análise sobre os dados e autoriza a vinculação do tripulante aos crachás, caso não haja impedimentos para isso, e informa à CODESP a respeito;

- A CODESP disponibilizará sete postos ao longo do cais para registrar a biometria e a foto de tripulantes. Desta forma, ficam autorizadas à saída dos mesmos da zona primária e a posterior entrada para que reembarquem no navio correspondente;

- Quando da desatracação do navio, as autorizações constantes nos crachás perdem a validade e poderão ser utilizados pelo Agente Marítimo para outros tripulantes.

- Estas informações ficam disponíveis para consulta pela Alfândega e Policia Federal, que podem, a qualquer tempo, solicitar o bloqueio do crachá de um tripulante ou seu descredenciamento, fatos esses informados em seguida ao Agente Marítimo.

Ficará a critério do dono do crachá, no caso o Agente Marítimo, o local e a forma de devolução do mesmo após sua devida utilização.

g) Regras especiais para acesso de caminhões (Transportador eventual, Motorista).

Haverá três alternativas para esse perfil, após a implantação, para que um caminhão obtenha acesso às áreas restritas do porto.

- Como Prestador de serviços do porto: o Responsável, que pode ser uma Transportadora ou um Operador portuário, deverá seguir os passos descritos no item d de Prestadores de serviços do porto de modo a obter autorização de acesso para motoristas e veículos. Quando se tratar de caminhoneiro autônomo, esse deverá comparecer ao setor de credenciamento da CODESP, munido dos documentos pessoais e do veículo, para que lá sejam registradas a biometria e foto e em seguida emitidos os crachás correspondentes. Os crachás ficarão de forma definitiva com o caminhoneiro 
autônomo, cabendo a ele revalidar os crachás assim que seus prazos de validade terminarem.

- Com vinculação de crachás: o Responsável poderá adquirir um lote de crachás destinados a Transportadores eventuais e cadastrar, sempre que necessário, os dados do motorista e os dados do caminhão bem como os crachás que os mesmos irão utilizar através do site do SSPP ou através do envio de arquivo de dados via SED, solicitando, assim, autorização de acesso às áreas restritas do porto. Esse cadastro deve ser feito antes da chegada do caminhão ao Gate, o Transportador eventual deverá apresentar seus documentos pessoais e do veículo para comprovação. Ficará a critério do dono do(s) crachá(s), no caso o Responsável, o local e a forma de devolução do(s) mesmo(s) após sua devida utilização.

- Caminhoneiros sem crachás: para aqueles caminhoneiros que chegam aos Gates de acesso sem estar de posse de crachá, a entrada somente será autorizada após a apresentação dos documentos do motorista e do veículo e preenchimento de formulário de solicitação de acesso.

Estas informações ficam disponíveis para consulta pela Alfândega e Polícia Federal, que podem, a qualquer tempo, solicitar o bloqueio do crachá ou acesso de um transportador eventual ou caminhoneiro autônomo ou seu descredenciamento, fatos esses informados em seguida ao Responsável.

Exige-se que toda e qualquer solicitação do Responsável no que se refere à revalidação de crachás deva ser feita pelo site do SSPP, tais como: inclusão ou exclusão de Gates de acesso, mudança de validade dos crachás, entre outras.

Essas operações poderão ser autorizadas somente pela CODESP, que exigirá o comparecimento do Responsável ao setor de credenciamento para fins de gravação dos dados atualizados nos crachás.

Além disso, todas as notificações de autorização ou bloqueio de crachás serão feitas através do envio de e-mail ao Responsável ou por sua consulta no site do SSPP." 17

${ }^{17}$ Cartilha do Controle de Acesso nas Áreas Restritas do Porto de Santos, disponível no sitio da SED em < http://www.superviadedados.com.br/_ftp/sspp\%20v8_2_4.pdf> 


\subsection{SUBSISTEMA DE CONTROLE DE ACESSO}

Todos os funcionários, prestadores de serviços, terceiros e demais pessoas autorizadas a acessar a faixa portuária e demais áreas controladas deverão estar portando um crachá com tecnologia Mifare ${ }^{18}$ de proximidade (rádio freqüência).

\subsubsection{CARACTERÍSTICAS TÉCNICAS DO CARTÃO DE ACESSO.}

O porto de Santos adotou um cartão inteligente (smart card) com chip Mifare, ícone em tecnologia no mercado nos últimos 10 anos, devido às suas qualidades, performance, versatilidade, facilidade de utilização e compatibilidade com as normas internacionais. Cartão de comunicação de dados sem contato físico com as seguintes características:

- Memória:

- EEPROM 1 Kbits: 16 setores (00 a OF) com 4 blocos de 16 bytes

- Retenção de dados - 10 anos

- Garantia de ciclos - 100000 R/W

- Freqüência:

○ $13.56 \mathrm{MHz}$

- Comunicação:

- $100 \mathrm{KBits} /$ segundo

- Segurança:

- Número Serial

- Bloco se segurança configurável

- Divisão de segurança

- Autenticação ativa

\footnotetext{
${ }^{18}$ Mifare é marca registrada Philips
} 


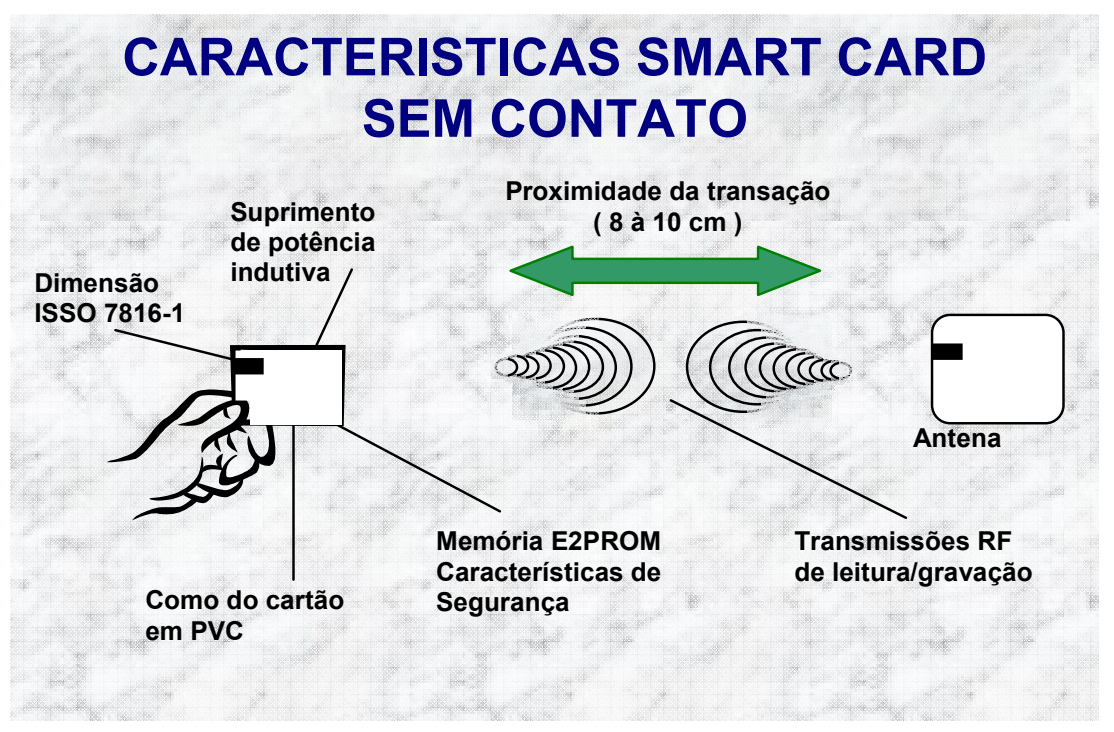

Figura 9: Característica do Smart Card

\subsubsection{HABILITAÇÃO DO CRACHÁ PARA O SSPP}

"O acesso às áreas restritas está ligado ao uso de cartão de acesso (crachá), que é ponto fundamental na identificação de pessoas e veículos e autenticação dos acessos.

Existirão dois tipos distintos de cartões, uma para pessoas e outro para veículos, sendo que cada um conterá informações específicas de controle. Não existirá um elo entre eles, ou seja, um cartão para pessoa não estará vinculado a um cartão de veiculo, permitindo qualquer combinação entre eles.

Somente a CODESP estará habilitada a emitir cartões de acesso no SSPP, mas independente do número de entidades habilitadas a emitir o cartão, sempre

O cartão Mifare permite a utilização de senhas distintas para cada setor, e podem ser configuradas de acordo com a aplicação. No SSPP, genericamente a primeira senha será utilizada para acesso a gravação do cartão e a segunda senha para leitura do cartão.

O setor não é identificado pelo seu número correspondente no cartão, e sim por uma seqüência alfabética, que servirá como indexação, pois a identificação física dos setores será feita pelo sistema emissor do cartão.

Os setores foram divididos de forma que as senhas possam ser gerenciadas conforme a necessidade de sigilo das informações nele contida. Atualmente quatro 
dos dezesseis setores do cartão foram utilizados, cabendo a CODESP num futuro o uso dos demais setores, por exemplo, para que seus funcionários utilizem o transporte público, cada setor foi dimensionado com campos em igualdade de sigilo e responsabilidade, a Tabela 5.1 abaixo descreve essas características:

Tabela 5.1: Tabela de setor

\begin{tabular}{|c|l|l|}
\hline Setor & Senha de gravação & Senha de leitura \\
\hline a & CODESP & $\begin{array}{l}\text { CODESP } \\
\text { OGMO } \\
\text { Terminais Privativos }\end{array}$ \\
\hline b & CODESP & $\begin{array}{l}\text { CODESP } \\
\text { OGMO } \\
\text { Terminais Privativos }\end{array}$ \\
\hline c & CODESP & $\begin{array}{l}\text { CODESP } \\
\text { OGMO } \\
\text { Terminais Privativos }\end{array}$ \\
\hline d & $\begin{array}{l}\text { CODESP } \\
\text { Terminais Privativos }\end{array}$ & $\begin{array}{l}\text { CODESP } \\
\text { Terminais Privativos }\end{array}$ \\
\hline
\end{tabular}

(*) Quando os terminais privados estiverem preparados para integrarem seus GATES ao SSPP o cartão para: Pessoas: a CODESP fornecerá as senhas de leitura conforme ANEXO I.

Veículos: a CODESP realizará o processo de input das senhas necessárias no equipamento dos terminais, evitando que as senhas de leitura sejam divulgadas diretamente. As senhas de gravação dos setores a, b e c nunca serão divulgada.

Os modelos dos cartões de acesso ou crachás para pessoas possuem características peculiares conforme o tipo de usuário e a área a ser acessada. No SSPP, foram criadas três classificações de áreas:

- Área de acesso administrativo: para o acesso de pessoas ou veículos é necessário credenciamento adequado e estar portando o crachá de acesso (tarja azul).

- Área de acesso controlado: para o acesso de pessoas ou veículos é necessário credenciamento adequado e estar portando o crachá de acesso (tarja verde ou vermelha).

- Área de acesso restrito: para o acesso de pessoas ou veículos é necessário credenciamento adequado e estar portando o crachá de acesso (tarja vermelha).

As pessoas autorizadas nesta categoria, também possuem acesso às áreas controladas (verde). 
Para que o cartão esteja habilitado ao uso no SSPP, deve conter os seguintes dados armazenados nos cartões de pessoas:

Tabela 5.2: Tabela dos registros de usuários

\begin{tabular}{|l|c|c|}
\hline \multicolumn{1}{|c|}{ Dados } & \multicolumn{1}{|c|}{$\begin{array}{c}\text { Tamanho } \\
\text { (bytes) }\end{array}$} & \multicolumn{1}{c|}{ Tipo } \\
\hline Código emissor & 1 & número \\
\hline Código tipo cartão & 1 & número \\
\hline Código tipo usuário & 1 & número \\
\hline Código de identificação & 16 & caractere \\
\hline Biometria & 9 & número \\
\hline NOGMO & 3 & número \\
\hline CPF & 6 & número \\
\hline Total do setor & 31 & \\
\hline Documento de identificação & 14 & caractere \\
\hline Nome & 34 & caractere \\
\hline Total do setor & 48 & \\
\hline Data acesso inicial & 2 & número \\
\hline Hora acesso inicial & 2 & número \\
\hline Período de acesso & 2 & número \\
\hline Gate (GT) & 32 & número \\
\hline Total do setor & 38 & \\
\hline Entrada & 1 & número \\
\hline Saída & 1 & número \\
\hline Total do setor & 2 & \\
\hline
\end{tabular}

- Código do emissor: código do emissor do cartão de acesso. Na fase 1 somente a CODESP emitirá cartões;

- Código do tipo de cartão: define o tipo do cartão, se para pessoas ou Veículos;

Tabela 5.3: Tabela dos tipos de cartão

\begin{tabular}{|c|l|}
\hline Código & \multicolumn{1}{|c|}{$\begin{array}{c}\text { Tipo } \\
\text { cartão }\end{array}$} \\
\hline 1 & Pessoa \\
\hline 2 & Veiculo \\
\hline 3 & Provisório \\
\hline 99 & Ocorrências \\
\hline 100 & Especiais \\
\hline
\end{tabular}

- Código do tipo de usuário: número pelo qual são identificados os tipos de usuários e suas respectivas características; 
Tabela 5.4: Tabela dos tipos de usuário

\begin{tabular}{|c|l|}
\hline Código & \multicolumn{1}{c|}{ Tipo } \\
\hline 1 & Visitantes \\
\hline 2 & Prestadores de Serviços CODESP \\
\hline 3 & Prestadores de Serviços do Porto \\
\hline 4 & Prestadores de Serviços da Alfândega \\
\hline 5 & Funcionários CODESP \\
\hline 6 & Funcionários OGMO \\
\hline 7 & Tripulantes \\
\hline 8 & Transportador eventual \\
\hline 9 & Funcionário Praticagem \\
\hline 10 & Funcionários Alfândega \\
\hline 11 & Diretoria CODESP \\
\hline 12 & Imprensa \\
\hline 13 & Funcionário de Sindicatos \\
\hline 14 & Funcionários de demais Autoridades \\
\hline 15 & Motoristas \\
\hline 16 & Trabalhadores Portuários Avulsos (TPA) \\
\hline 99 & Ocorrências \\
\hline 100 & Autoridade \\
\hline &
\end{tabular}

- Código de identificação: código de uso interno é o número da credencial de cada tipo de usuário. Para os TPA será usado o número OGMO, para CODESP o número funcional, etc.;

- Biometria: informação biométrica da geometria da mão do usuário;

- NOGMO: número de identificação exclusivo do TPA. É o número OGMO. Para as pessoas que possuem somente perfil de TPA, este conteúdo será redundante com o campo "Código de identificação", para pessoas que possuem também outro perfil, estes campos serão diferentes.

- CPF: CPF do portador. Sempre que possível, o CPF deve ser utilizado como a primeira identificação da pessoa. Tripulantes podem não possuir CPF;

- Documento de identificação: Registro Geral - RG do portador. Pode ser utilizado para outros documentos, quando o RG não se aplicar;

- Nome: nome do portador;

- Data inicial de acesso: data inicial do período de acesso;

- Hora inicial de acesso: hora inicial do período de acesso;

- Período de acesso: quantidade de horas de acesso;

- Gates: locais de acesso. Não haverá limite de quantidade de Gates onde uma pessoa poderá ter acesso, podendo estar habilitada a um, vários ou todos os Gates previstos; 
- Entrada: nível hierárquico do local onde ocorreu à última entrada;

- Saída: nível hierárquico do local onde ocorreu à última saída.

Mapa de memória do cartão de pessoas:

Tabela 5.5: Tabela dos dados do cartão de pessoas

\begin{tabular}{|c|c|l|}
\hline Bloco & Bytes (0-15) & \multicolumn{1}{c|}{ Campo } \\
\hline 3 & Senhas & Setor a \\
\hline 2 & I I I I I I I I I I I I I I I & 1=Código de identificação \\
\hline 1 & ETU----BBBBBBBBB & $\begin{array}{l}\text { E=Código Emissor; T=Tipo cartão; U=Tipo Usuário; } \\
\text { B=Biometria. }\end{array}$ \\
\hline 0 & OOO------CCCCCC & O=Número OGMO; C=CPF. \\
\hline 3 & Senhas & Setor b \\
\hline 2 & RRRRRRRRRRRRRRNN & R=RG; N=NOME \\
\hline 1 & NNNNNNNNNNNNNNNN & \\
\hline 0 & NNNNNNNNNNNNNNNN & \\
\hline 3 & Senhas & Setor c \\
\hline 2 & DDHHPP-------- & D=Data inicio acesso; H=hora inicio acesso; P=Período \\
de acesso em horas.
\end{tabular}

Modelo de crachás para pessoas:
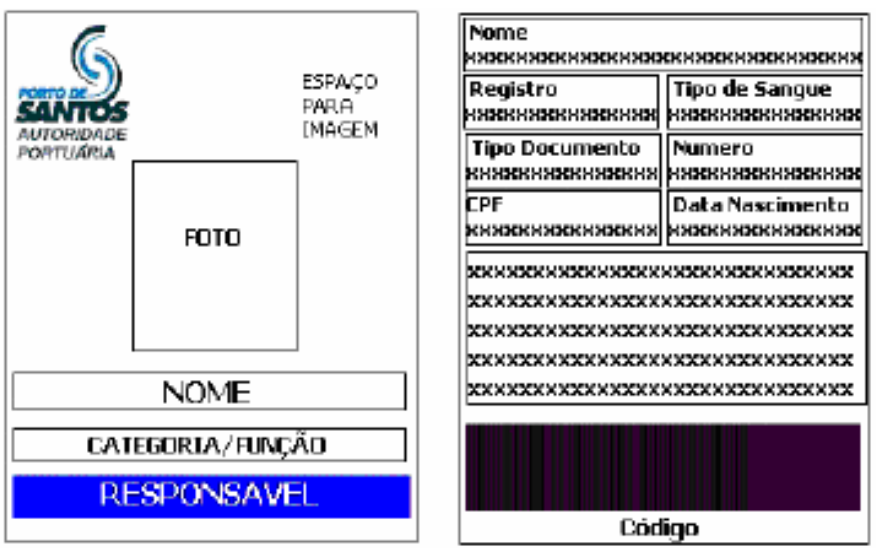

Figura 10: Crachá de pessoas com acesso contínuo (prestadores de serviço, TPA, etc.)

Para que o cartão esteja habilitado ao uso no SSPP, deve conter os seguintes dados armazenados nos cartões de veículos: 
Tabela 5.6: Tabela dos dados do veículo

\begin{tabular}{|c|c|c|}
\hline Dados & $\begin{array}{l}\text { Tamanho } \\
\text { (bytes) }\end{array}$ & Tipo \\
\hline Código etrissor & 1 & nutituero \\
\hline Código tijo cattao & 1 & fintutuero \\
\hline Código tipo usuário & 1 & nulituero \\
\hline Código de identificaçăo & 16 & caractere \\
\hline Codigo do RENA WAM & 6 & nưlnero \\
\hline Chassi & 20 & caractere \\
\hline Total do setor & 45 & \\
\hline $\begin{array}{l}\text { Docutrento de identificação } \\
\text { do proprietário }\end{array}$ & 8 & nultrtero \\
\hline Marca/Modelo & 25 & caractere \\
\hline Cor & 8 & caractere \\
\hline Flaca & 7 & caractere \\
\hline Total do setor & 48 & nưltuero \\
\hline Data acesso inicial & 2 & nuluttero \\
\hline Hora acesso inicial & 2 & nuituero \\
\hline Periodo de acesso & 2 & nulituero \\
\hline Gates (GT) & 32 & nulituero \\
\hline Total do setor & 38 & \\
\hline Entrada & 1 & nutuero \\
\hline Total do setor & 1 & \\
\hline
\end{tabular}

- Código do emissor: código do emissor do cartão de acesso. Na fase 1 somente a CODESP emitirá cartões;

- Código do tipo de cartão: define o tipo do cartão, se para pessoas ou

\section{Veículos;}

Tabela 5.7: Tabela dos tipos de veículos

\begin{tabular}{|c|l|}
\hline Código & \multicolumn{1}{|c|}{ Tipo } \\
\hline 1 & Veiculo de Visitantes \\
\hline 2 & Veiculo de Prestadores de Serviços CODESP \\
\hline 3 & Veiculo de Prestadores de Serviços do Porto \\
\hline 4 & Veiculo de Prestadores de Serviços da Alfândega \\
\hline 5 & Veiculo de Funcionários CODESP \\
\hline 6 & Veiculo de Funcionários OGMO \\
\hline 8 & Veiculo de Transportador eventual \\
\hline 9 & Veiculo de Funcionário Praticagem \\
\hline 10 & Veiculo de Funcionários Alfândega \\
\hline 11 & Veiculo de Diretoria CODESP \\
\hline 12 & Veiculo de Imprensa \\
\hline 13 & Veiculo de Funcionário de Sindicatos \\
\hline 14 & Veiculo de Funcionários de demais Autoridades \\
\hline 15 & Veiculo de Motoristas \\
\hline 50 & Veiculo Carga* \\
\hline 99 & Ocorrências \\
\hline 100 & Usuário Especial \\
\hline & \\
\hline
\end{tabular}

(*) Este veículo possui características especiais, é uma "carga", ou seja, é uma mercadoria que está sendo embarcada ou desembarcada. Neste caso não possuirá informações de identificação e não será controlada a hierarquia de acesso, normalmente entra e não sai ou sai e não entra das áreas restritas. 
Código do tipo de usuário: número pelo qual são identificados os tipos de usuários e suas respectivas características;

- Código de identificação: código de uso interno é o número da credencial de cada tipo de usuário. Para os TPA será usado o número OGMO, para CODESP o número funcional, etc;

- Biometria: informação biométrica da geometria da mão do usuário;

- CPF: CPF do portador. Sempre que possível, o CPF deve ser utilizado como a primeira identificação da pessoa. Tripulantes podem não possuir CPF;

- Documento de identificação: RG do portador. Pode ser utilizado para outros documentos, quando o RG não se aplicar;

- Código RENAVAM: código RENAVAM (Registro Nacional de Veículos Automotores) do veículo;

- Chassi: código do chassi do veículo;

- Documento de identificação do proprietário: CPF para pessoas físicas e Cadastro Nacional de Pessoa Jurídica - CNPJ para jurídicas;

- Marca/modelo: marca e modelo do veículo, conforme Departamento Estadual de Trânsito - DETRAN;

- Cor: cor predominante do veículo;

- Placa: placa do veículo;

- Data inicial de acesso: data inicial do período de acesso;

- Hora inicial de acesso: hora inicial do período de acesso;

- Período de acesso: quantidade de horas de acesso;

- Gates: locais de acesso. Não haverá limite de quantidade de Gates onde uma pessoa poderá ter acesso, podendo estar habilitada a um, vários ou todos os Gates previstos;

- Entrada: nível hierárquico do local onde ocorreu à última entrada; 
Mapa de memória do cartão de veículos:

Tabela 5.8: Tabela dos dados do cartão de veículo

\begin{tabular}{|c|c|c|}
\hline Bloco & Bytes (0-15) & Campo \\
\hline 3 & Senhas & Setor a \\
\hline 2 & I I I I I I I I I I I I I I I I & 1=Código de identificação \\
\hline 1 & ETU----HHHHHHHHH & $\begin{array}{l}\mathrm{E}=\text { Código Emissor; T=Tipo cartão; U=Tipo Usuário; } \\
\mathrm{H}=\text { Chassi. }\end{array}$ \\
\hline 0 & HHHHHHHHHHRRRRRR & $\mathrm{R}=$ Renavan \\
\hline 3 & Senhas & Setor b \\
\hline 2 & DDDDDDDDCCCCCCCC & $\mathrm{D}=$ Documento do proprietário; $\mathrm{C}=$ Cor. \\
\hline 1 & MMMMMMMMMMMMMMMM & $\mathrm{M}=($ continuação bloco zero $)$ \\
\hline 0 & PPPPPPPMMMMMMMMM & P=Placa; M=Marca/modelo. \\
\hline 3 & Senhas & Setor C \\
\hline 2 & DDHHPP----------- & $\begin{array}{l}\mathrm{D}=\text { Data inicio acesso; } \mathrm{H}=\text { hora inicio acesso; } \mathrm{P}=\text { Período } \\
\text { de acesso em horas. }\end{array}$ \\
\hline 1 & LLLLLLLLLLLLLLLL & $\mathrm{L}=$ Locais de acesso \\
\hline 0 & LLLLLLLLLLLLLLLL & \\
\hline 3 & Senhas & Setor d \\
\hline 2 & H-------------- & $\mathrm{H}=$ Nível hierárquico do local de acesso (inicialmente=255) \\
\hline 1 & ----------------- & \\
\hline 0 & |---------------- & \\
\hline
\end{tabular}

Modelo de crachás para veículos:
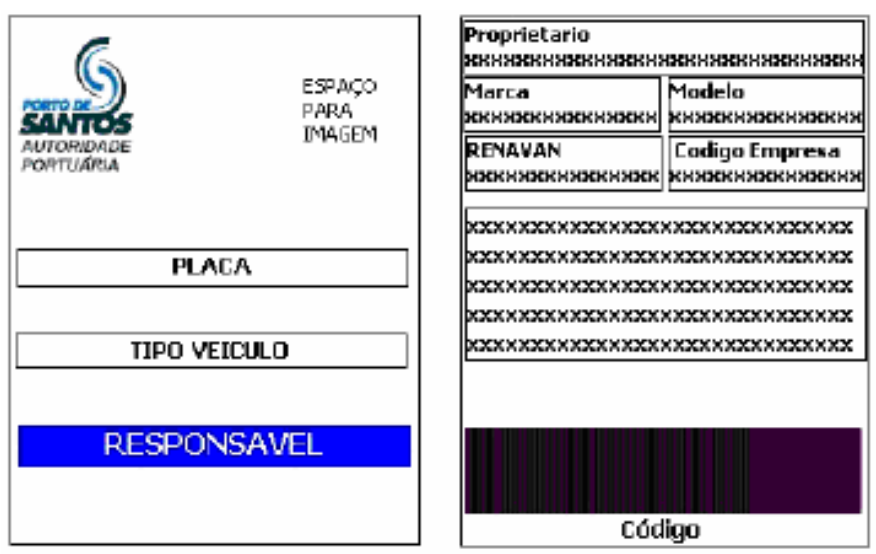

Figura 11: Crachá de veículos de prestadores de serviços. 

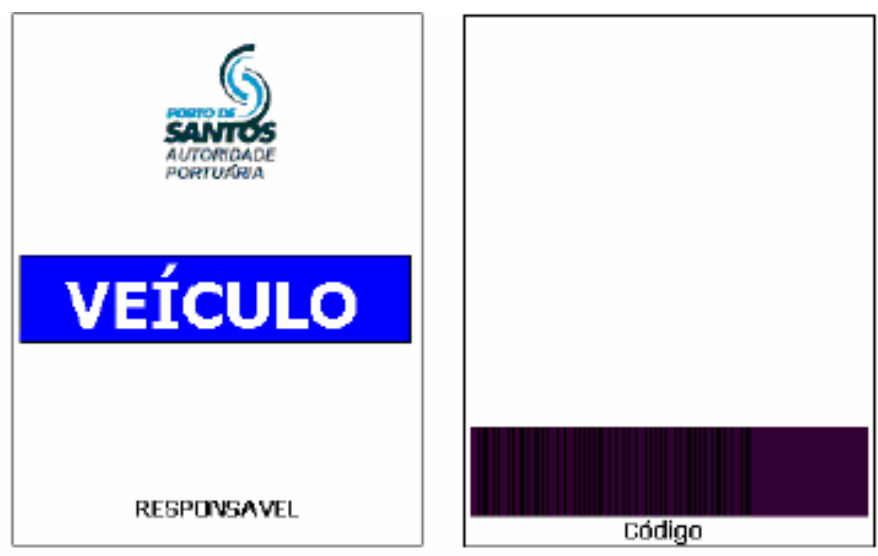

Figura 12: Crachá de veículo de visitantes e transportadores

Os locais de acesso possuem funcionalidades específicas para validação ou bloqueio de acessos às áreas controladas eletronicamente. Para validar um acesso, os locais de acesso dos Gates devem tratar de forma diferenciada cada tipo de cartão e cada perfil de usuário.

Para o SSPP, é prevista uma hierarquia de acesso nas áreas restritas do porto de modo a não permitir que uma pessoa ou veículo acesse uma mesma área mais de uma vez, caracterizando, assim, uma forma ilegal de acesso, pois se uma pessoa já adentrou em uma área, não deve ser permitido um novo acesso de entrada a esta mesma área. A hierarquia é definida a partir do lado mais externo (área pública), que recebe código 0 (zero), e segue para outras áreas mais internas, cujos códigos são incrementados de 1 respectivamente a sua hierarquia.

Cada local físico tem um nível hierárquico de acesso relacionado, e todo acesso redundante (entrada ou saída) deve ser bloqueado para um mesmo nível hierárquico.

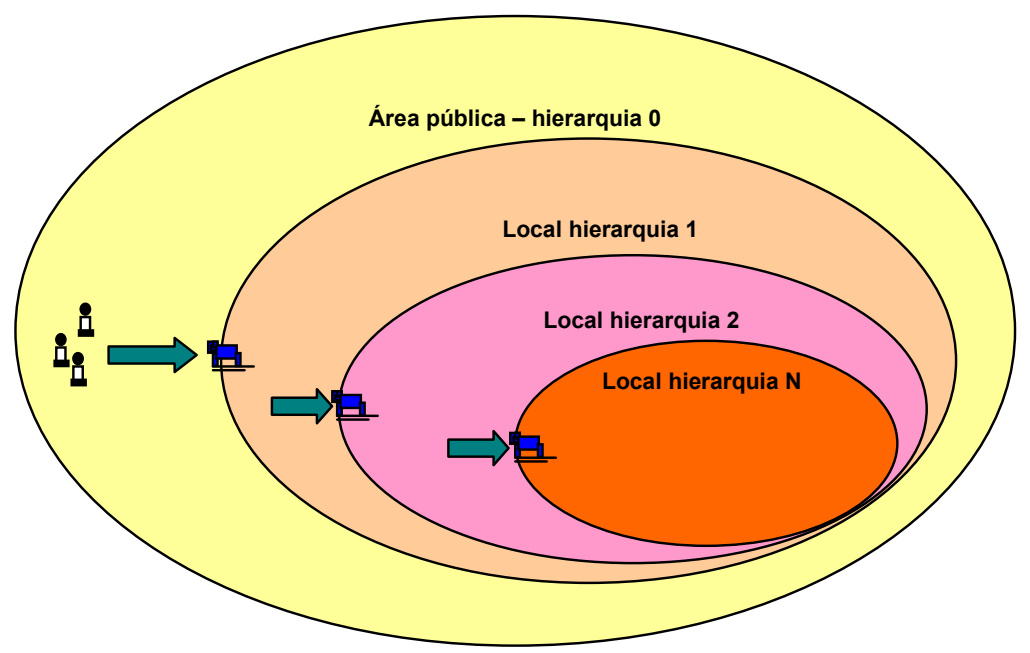

Figura 13: Código de hierarquia dos locais de acesso 
Exemplo prático: Se uma pessoa já adentrou a uma área de hierarquia 2, somente poderá acessar áreas de hierarquia 3 se estiver habilitado ou sair para áreas de hierarquia 1 ou zero (pública).

A hierarquia de acesso será controlada somente para usuários que possuem características que permitam e necessitam deste controle, caso dos TPA por exemplo.

Alguns usuários entram em área restrita, mas não saem por elas, como é o caso dos Práticos, que acessam a área restrita para acesso a embarcações, e após realizarem seu trabalho a bordo, retornam para áreas não restritas.

No bloqueio de acesso, foi criada a chamada Lista Negra por Local, cujo objetivo é relacionar todos os cartões cancelados ou que possuem restrições de local de acesso.

Portanto, existem duas situações onde um cartão constará nesta lista:

Cartão bloqueado: por algum motivo o cartão foi cancelado (perda, roubo, cancelado pelas autoridades e órgãos governamentais, etc.);

Locais bloqueados: por algum motivo, um ou vários locais que estão habilitados no cartão foi bloqueado, mas os outros continuam válidos;

A Lista Negra por Local permite solucionar os casos onde o SSPP necessita bloquear o acesso de um cartão a um determinado local sem cancelar todo o cartão.

Exemplo prático: Um cartão de pessoa inicialmente foi habilitado a acessar os Gates 3, 8, 15 e 20. Mas agora desejamos bloquear o acesso desta pessoa somente aos locais 8 e 15, e continuar permitindo o acesso aos locais 3 e 20, sem cancelar o cartão ou regrava-lo.

O cartão continuará habilitado para os locais $3,8,15$ e 20, mas constarão na Lista Negra por Local os locais 8 e 15.

Esta solução é necessária devido às necessidades constatadas nos procedimentos do porto."

A Figura 14 demonstra o processo de cadastramento e credenciamento de veículos e pessoas para a obtenção do acesso das áreas restritas da CODESP através de transações eletrônicas. 


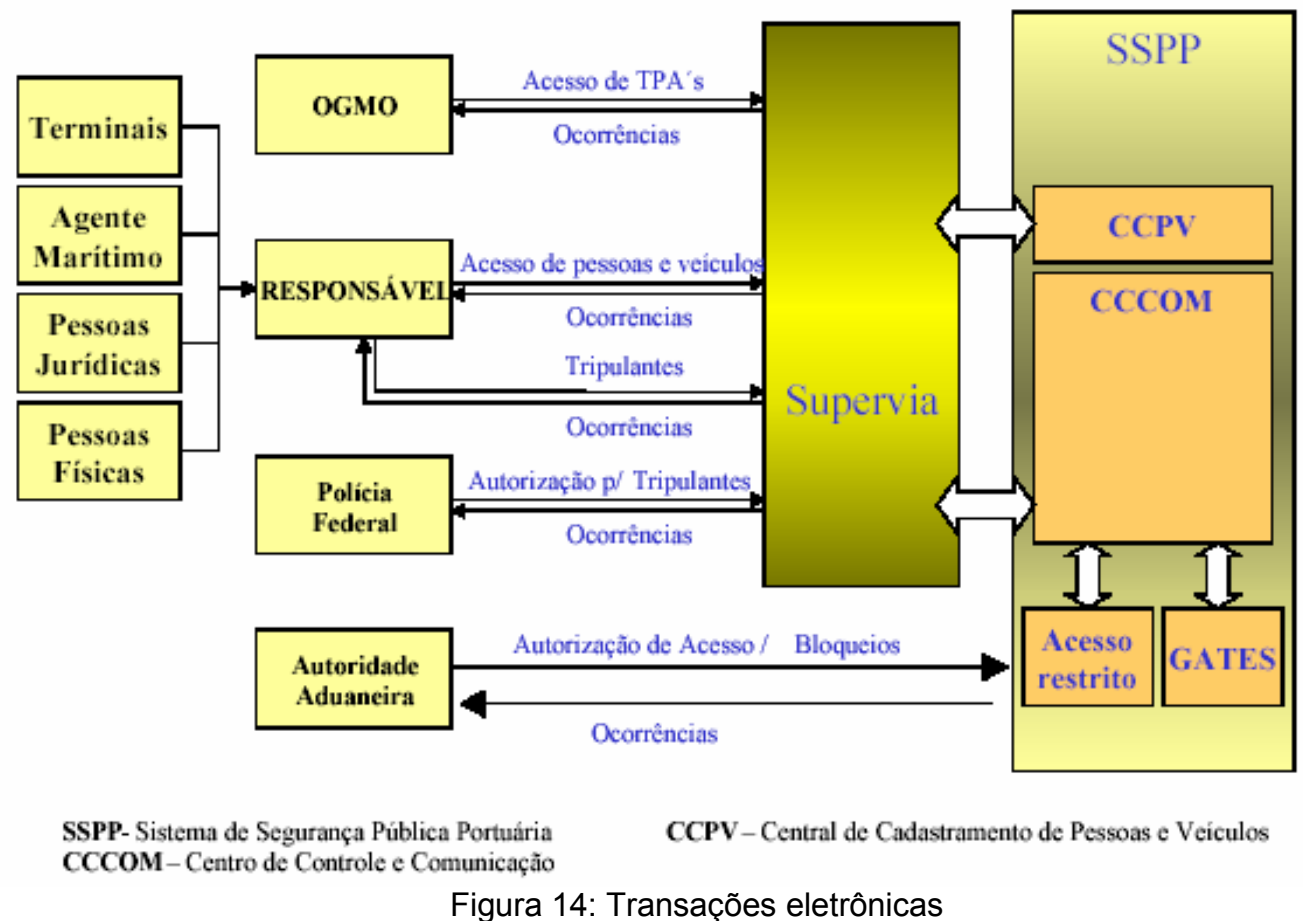

Figura 14: Transações eletrônicas

\subsubsection{TECNOLOGIA PARA O CONTROLE DE ACESSO}

O sistema de controle de acesso utiliza a tecnologia $\mathrm{MDC} 3000^{19}$, que está descrita a seguir. A seqüência para liberação de um acesso se dará pela seqüência:

1) Leitura do cartão e identificação do usuário;

2) Existindo o usuário, verificação se o mesmo está ou não bloqueado no sistema;

3) Não havendo bloqueio, verificação dos direitos de acesso do usuário. Os direitos de acesso devem estar gravados no cartão e irão definir o período (em dias) e os Gates e portarias nos quais os usuários possuem acesso liberado.

4) Havendo a liberação, há uma solicitação da identificação biométrica para validação final do usuário.

Se a verificação for verdadeira, a catraca, torniquete ou cancela deverá ser liberada para o acesso do funcionário ou prestador de serviços, caso contrário a

\footnotetext{
${ }^{19}$ Software implantado no porto de Santos pela empresa Trielo Soluções Inteligentes
} 
catraca deverá ser mantida travada. Os avisos também deverão ser dos tipos luminosos e sonoros.

Os deficientes físicos deverão ter seus acessos através de portões de passagem próprios para este fim. Será necessária verificação para liberação do acesso.

Os visitantes deverão se identificar no balcão de atendimento, onde será feito o cadastro de suas informações e captura de sua foto. No cartão do visitante serão gravados seus direitos de acesso. Após a identificação o visitante receberá um crachá Mifare de proximidade que deverá ser apresentado ao leitor da catraca para que esta seja liberada e ele ganhe o acesso solicitado.

Na saída, o visitante deverá depositar o crachá em uma catraca para que esta seja liberada e ele possa sair. Com estes procedimentos serão minimizadas as possibilidades de que os visitantes levem os crachás consigo ou por descuido ou intencionalmente.

Para o controle de acesso de pedestres foram instalados mini-bloqueios (catracas) do tipo balcão, com três braços e acabamento em aço inox escovado ou torniquetes (acesso às áreas molhadas e restritas);

Será instalado, nas salas de controle dos Gates e portarias, um dispositivo de acionamento (botoeira tipo push button) de abertura emergencial das catracas, torniquetes e cancelas. O dispositivo controlará a alimentação fornecida e quando acionado cortará esta alimentação ou fornecerá um contato para acionar a abertura da catraca, torniquetes ou da cancela. Para o acionamento do dispositivo bastará pressionar o botão.

Nas portarias de acesso de veículos também haverá estações para cadastramento dos motoristas, que deverão se encaminhar às estações para a identificação, cadastramento e liberação dos mesmos.

\subsubsection{CARACTERÍSTICAS TÉCNICAS DO MDC3000}

Quanto à arquitetura do MDC3000 há 4 elementos básicos que necessitam ser identificados: 
- Servidor de arquivos;

- Concentradoras;

- Estações de trabalho;

- Coletores de Dados;

Para facilitar o entendimento a Figura 15 demonstra a arquitetura geral, para melhor entendimento dos 4 elementos acima citados é necessário que inicialmente sejam identificados 2 ambientes que se integram para o perfeito funcionamento do sistema MDC3000:

- A rede de comunicação dos microcomputadores (rede ethernet);

- A rede de comunicação das controladoras (rede ethernet).

A rede de comunicação dos microcomputadores possibilita a interligação entre o servidor de arquivos, as concentradoras e as estações de trabalho. A rede de comunicação dos coletores de dados permite a ligação destes com a rede dos microcomputadores. A concentradora, conforme a seguir, é responsável logicamente pela interface entre as duas redes.

Servidor de Arquivos é o equipamento onde fisicamente fica localizada a base de dados do MDC3000. Esta base é compartilhada pelas concentradoras e pelas estações de trabalho. Através das concentradoras a base de dados é atualizada nos coletores de dados, ou de forma on-line ou de forma off-line (em "batch"). Atualmente o MDC3000 trabalha com base de dados nos padrões de SGBD MSAccess, MS-SQLServer e Oracle. Para o projeto do porto de Santos a base de dados é Oracle.

Concentradoras são equipamentos de arquitetura PC, onde é instalado o programa MDC3000 e que se comunica com o servidor de arquivos e com os coletores de dados através da rede ethemet.

As concentradoras realizam a interface entre a base de dados localizada no servidor de arquivos e os coletores de dados. São microcomputadores que gerenciam a troca de informações entre os coletores e a base de dados do sistema. 
São responsáveis pelo protocolo de comunicação entre as informações dos coletores e a base de dados do sistema (mantendo o sincronismo entre elas).

A interface de controle entre os coletores e a base de dados e a parte da lógica de comandos (acionamentos e verificações) é realizada por um módulo especial, MDCBe, desenvolvido em Java. Trata-se de aplicação "multithread"20 que se comunica com os coletores de dados através de protocolo UDP-IP (User Datagram Protocol). O sistema pode trabalhar com até 99 concentradoras e não há limite lógico para o número de coletores de dados gerenciados por uma concentradora. Este número depende da capacidade de processamento da concentradora e sugere-se até 30 coletores de dados (controladoras) por concentradora.

Os coletores de dados (ou controladoras) são instalados remotamente junto às catracas, torniquetes, cancelas e portas e possuem processamento local. Eles se comunicam com o sistema de controle de acesso através de uma rede ethemet. As concentradoras gerenciam grupos de controladoras, trocando com elas informações via protocolo UDP-IP. As controladoras enviam as transações geradas (entrada permitida, senha inválida, unidade não permitida e outras) e recebem atualizações e comandos. Essas controladoras possibilitam o processamento distribuído e independente. Há funções que dependem da comunicação on-line com a concentradora e que ficam prejudicadas quando a mesma não está funcionando, tais como:

- Liberação de um visitante em uma portaria;

- Entrega e devolução de crachás provisórios;

- Controle de fluxo;

- Liberação ou bloqueio de um funcionário;

- Inclusão de um novo funcionário;

- Gerenciamento de alarmes e intertravamentos; e

- Rastreamento on-line.

O controle de acesso fica funcionando com as bases de dados dos coletores de dados atualizadas até o instante em que as mesmas perdem a comunicação com as respectivas concentradoras, o que é suficiente para atender a grande massa de

\footnotetext{
${ }^{20}$ Processamento Multithread torna possível a execução de várias tarefas por um mesmo programa
} 
usuários do sistema, realizando todos os controles no que diz respeito às liberações e bloqueios (consistindo normalmente os direitos de acesso) e também ao armazenamento das transações geradas. Quando a comunicação é restabelecida os coletores e as concentradoras realizam o sincronismo entre suas informações (os coletores transmitindo as transações para as concentradoras e as concentradoras transmitindo as últimas atualizações que ainda não haviam sido transmitidas para os coletores).

Com a utilização dos cartões Mifare, a verificação dos direitos de acesso e templates irão se basear na leitura das informações gravadas nos cartões.

Estações de Trabalho são os microcomputadores nos quais está instalado o software MDC3000 e que acessam a base de dados através da rede local ethernet. Estes equipamentos podem possuir utilizações variadas, como por exemplo:

- Controle de portaria;

- Inclusão, alteração e exclusão de informações;

- Gerenciamento do sistema; e

- Manutenção da base de dados.

Arquitetura Geral

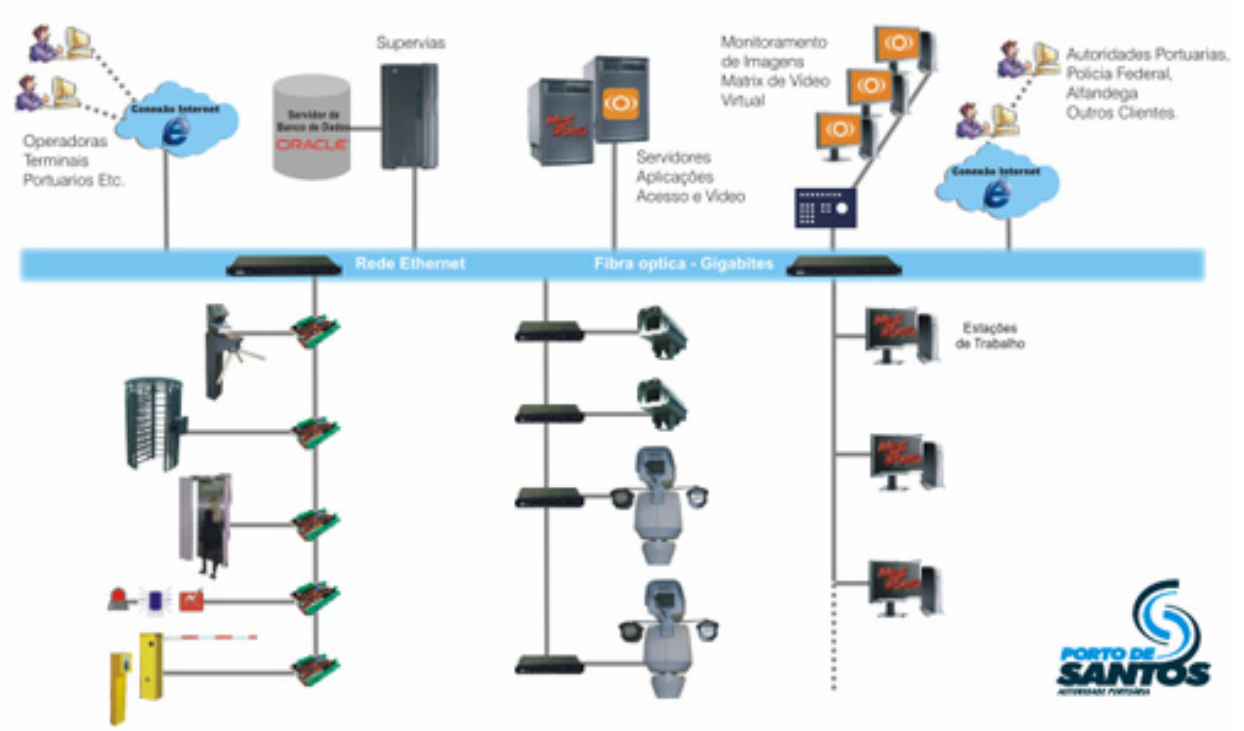

Figura 15: Fluxos da Arquitetura Geral 


\subsection{SUBSISTEMA DE CIRCUITO FECHADO DE TV (CFTV)}

O sistema de gestão de serviços de vídeo SmartSight ${ }^{21}$ constitui uma solução abrangente e dinâmica, desde uma até várias centenas de câmeras em incrementos de uma em uma câmera, oferecendo as funcionalidades e características aqui descritas. O SmartSight inclui dois módulos de:

- Módulos do Servidor de Vídeo Digital (SVD)

- Módulos da Estação Cliente

Todos os sinais digitais de vídeo provenientes das câmeras serão codificados em formato MPEG-4 e gravados em tempo real e simultaneamente, com bandas desde $8 \mathrm{kbits} / \mathrm{seg}$. até $4 \mathrm{Mbits} / \mathrm{seg}$., freqüências de quadros de 1 a 30 quadros por segundo e resoluções desde 1/4 CIF - Common Intermediate Format - (176 x 144 pixels) até $4 \mathrm{CIF}(704 \times 480$ pixels). O sistema é capaz de transmitir vídeo a 30 quadros por segundo em resolução CIF $(352 \times 240)$ usando banda de até 512 $\mathrm{kbits} / \mathrm{seg}$.

A freqüência de sinal digital (bit rate), freqüência de quadros e resolução de cada uma das câmeras são passíveis de ajustes independentes para cada câmara.

O sistema SmartSight não necessita de equipamentos de gravação específicos, nem multiplexadores de hardware ou tecnologia de divisão no tempo para gravação de áudio ou vídeo. O SmartSight é baseado numa arquitetura aberta que permite a utilização de equipamentos e subsistemas de armazenamento genéricos, que não limitam a capacidade de armazenamento, podendo esta ser ampliada gradativamente.

O SmartSight é compatível com múltiplos teclados de controle para operação das câmeras e suas funcionalidades PTZ (Pan, Tilt, Zoom), suportando os principais protocolos de controle disponíveis no mercado e não limitando a utilização de câmeras e controladores de diferentes fabricantes por exemplo, controles de teclado Pelco ${ }^{22}$ e câmeras Panasonic ou vice-versa). Os diferentes teclados e controladores

\footnotetext{
${ }^{21}$ SmartSight é marca registrada da Verint.

${ }^{22}$ Pelco Inc. empresa de projeto, desenvolvimento e fabricação de sistemas de vídeosegurança.
} 
são passíveis de conexão ao codificador/decodificador através de sua porta serial, permitindo seu controle com o uso de um computador PC genérico. O sistema adere a padrões abertos para serviços vídeo sobre IP, permitindo que aplicativos de tratamento de vídeo de terceiros possam se comunicar e integrar com o sistema.

O SmartSight permite o acoplamento de subsistemas de armazenamento de longo prazo através de qualquer unidade de backup compatível com o sistema Windows.

Os trechos (clipes) de vídeo arquivados são encriptados através de chave público-privada de pelo menos 248 bits com facilidades para a troca de chaves pelo usuário. O canal de controle dos serviços de vídeo sobre IP é encriptado segundo o padrão SSL - Secure Socket Layer.

O SmartSight é compatível com a infra-estrutura técnica para serviços de vídeo via IP denominada VSIP (Open Technical Framework for Vídeo Services) que permite a terceiros o desenvolvimento de aplicativos e dispositivos tais como Servidores de Vídeo Digitais que podem ser integrados a sistemas aderentes a este padrão. O canal de controle VSIP é encriptado utilizando SSL.

Os registros de tempo nas gravações de vídeo utilizam UTC (Universal Time Coordination) para assegurar a precisão e confiabilidade da localização dos itens de interesse. 


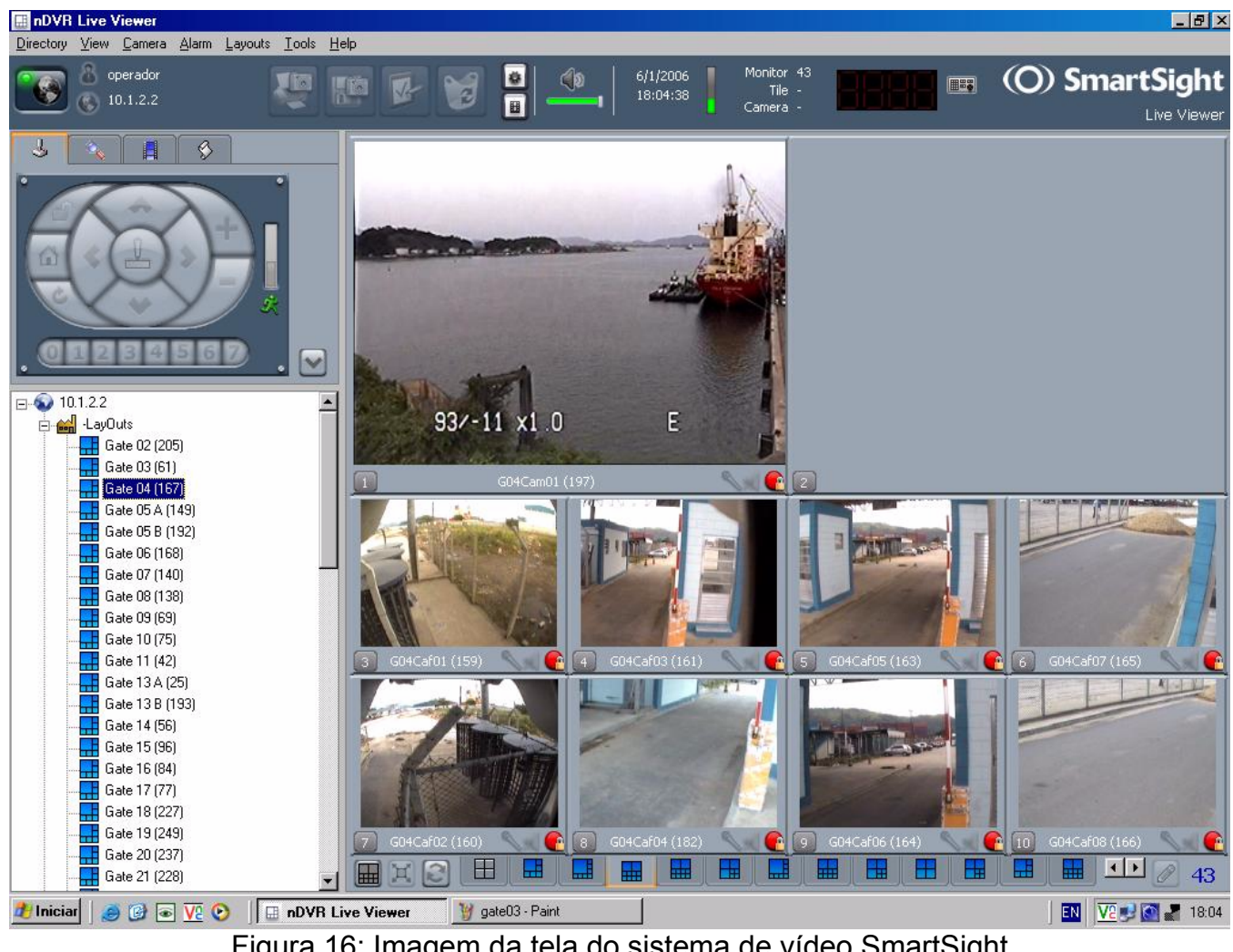

Figura 16: Imagem da tela do sistema de vídeo SmartSight

\subsection{SUBSISTEMA GESTOR DE EVENTOS}

O CCCom contará com o Sistema Gestor de Eventos, uma aplicação desenvolvida para integrar de forma rápida e eficiente o sistema de vigilância baseada em vídeo digital nDVR uma solução com tecnologia que permite simultaneamente visualizar, armazenar, e capturar com qualidade, resolução de voz, vídeo, e dados com sistemas emissores de alarmes e eventos.

A base para integração com o nDVR, um produto desenvolvido para gerenciamento de ativos digitais.

A solução de Gestão de Ativos Digitais cria um ambiente colaborativo para produção de documentos, imagens, vídeos, etc. Este ambiente integra diferentes plataformas de trabalho: Unix, Linux, Windows, Macintosh, Sistemas Operacionais Proprietários e compartilhar os arquivos existentes em cada uma dessas máquinas que compõe o ambiente colaborativo de trabalho. 


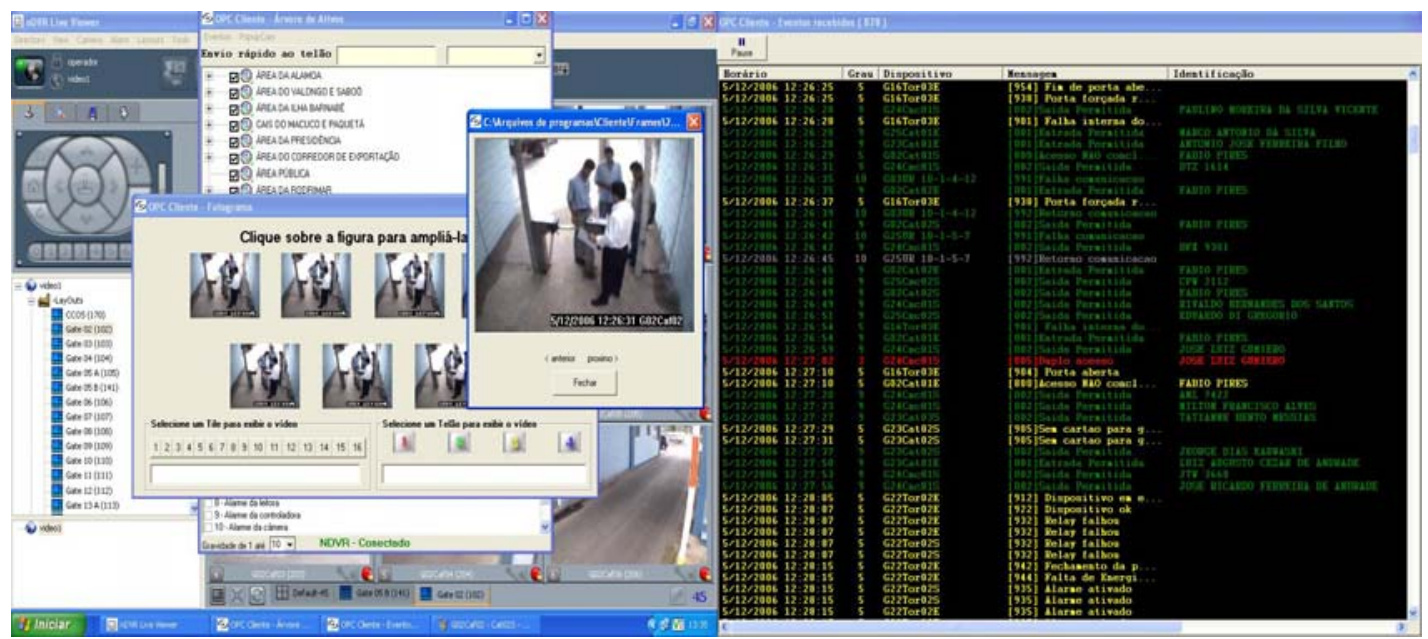

Figura 17: Imagem do gestor de eventos do OPC cliente de monitoração.

Tipos de ativos gerenciados pelo Gestor de eventos:

- Zona (assettypeid 301): A zona representa uma área geográfica com limites estabelecidos. Elas precisam apresentar uma forma hierárquica de estruturação, pois uma zona tem subzonas.

Metadados:

- assetid: identificador único no Gestor de Eventos

- zonaid: identificador da zona estabelecido pela CODESP

- hierarquia: posição relativa na hierarquia conforme o referencial da zona pública que tem hierarquia 0 . Conforme avança um degrau na hierarquia adiciona-se 1 ponto no valor da hierarquia.

- Gate (assettypeid 309):

O Gate estabelece o relacionamento entre duas zonas. Como o nome diz, trata-se da porta de passagem entre zonas. As zonas estão organizadas de forma hierárquica e os Gates estão associados às zonas. Nunca deve existir uma zona abaixo de um Gate.

Metadados:

- assetid: identificador único no Gestor de Eventos 
- gateid: identificador do Gate estabelecido pela CODESP, este id deve variar de 0 até 255

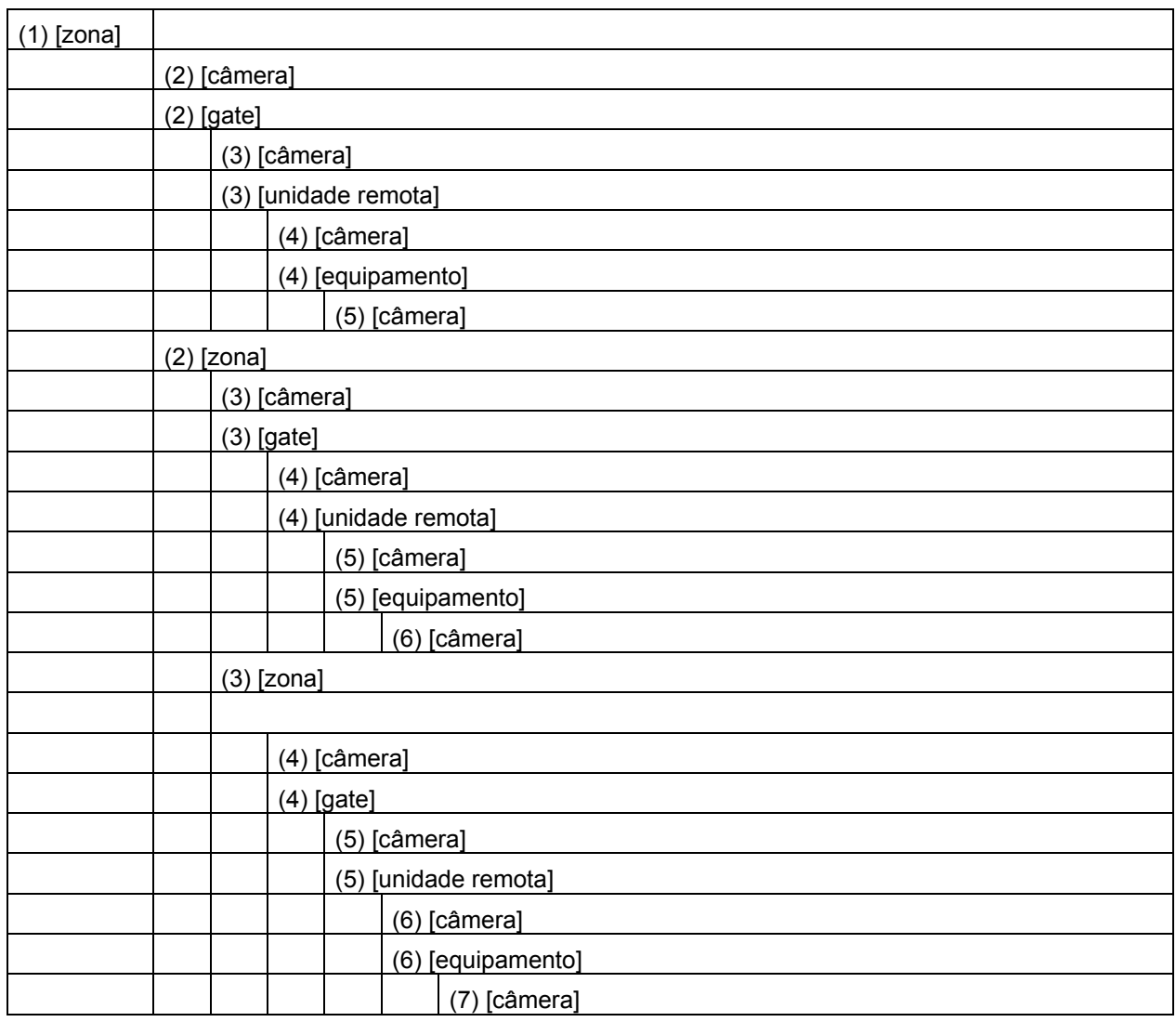

Figura 18: Tipos de Ativos

- Crachá (assettypeid 302): O ativo de tipo crachá representa o crachá Mifare que os usuários utilizam para acionar os dispositivos de controle de acesso. Cada crachá tem um número de série que não pode ser modificado.

Metadados:

- assetid identificador único no Gestor de Eventos

- badgeid: número de série do crachá

- tipo do cartão: catraca, cancela, torniquete,porta,câmera e vídeo.

- A estrutura hierárquica deve obedecer as seguintes regras:

- As zonas estão organizadas de forma hierárquica.

- Uma zona pode ter várias zonas filhas e estão conectadas umas às outras através dos Gates.

- Uma zona também pode ter mais de um pai, desde que a hierarquia se mantenha consistente. 
- O pai normalmente é um Gate.

- Um Gate está associado a duas zonas: zona de entrada e zona de saída.

- Eventualmente pode ter mais zonas, como por exemplo, um Gate que conecta 3 zonas (esta situação não é comum).

- O pai do Gate sempre deve ser uma zona.

- A unidade remota necessariamente tem como pai um Gate.

O Gate pode ter várias unidades remotas. Os equipamentos sempre estão associados às unidades remotas em uma relação de pai-filho (a unidade remota é que controla o equipamento, ela é o pai do equipamento).

Os equipamentos correspondem aos dispositivos físicos de leitura de cartão e são associados às catracas, cancelas, torniquetes e portas. São as leitoras de fato.

As câmeras são distribuídas livremente sobre a estrutura e uma vez estabelecidas uma relação pai (equipamento)-filho (câmera), significa que a câmera (filho) está monitorando esse equipamento (pai). Eventualmente um equipamento pode ser monitorado por mais de uma câmera.

Resumindo: Gates são os pontos de conexão entre as zonas. Mesmo que uma zona só tenha um Gates é melhor manter esta estruturação para permitir a inclusão dos terminais privados cujo modelo pode ser mais complexos que o existente hoje na CODESP.

Um evento sempre está associado com um ativo, pode ser, por exemplo, um crachá passando pela cancela, ou qualquer outro tipo de evento monitorado pelo sistema, como intrusões ou alertas de fumaça.

A lista apresentada a seguir descreve os tipos e subtipos de eventos que são gerenciados pelo Media Portal ${ }^{23}$ conforme especificação feita pela CODESP. Os tipos aparecem entre parênteses e os subtipos entre colchetes.

(1) Acesso solicitado

(2) Acesso negado, veja as subcategorias.

[801] Cartão não cadastrado

[802] Biometria da mão inválida

${ }^{23}$ Software utilizado na pesquisa dos eventos gerados no Gestor de Eventos. 
[803] Sem validade: período expirado

[804] Local inválido: não tem acesso ao Gate

[805] Duplo acesso: mesma hierarquia

[806] Cartão inválido

[807] Cartão bloqueado

(3) Acesso autorizado, veja as subcategorias.

[001] Entrada permitida

[002] Saída permitida

[101] Entrada especial (ocorre quando o tipo do cartão é 100)

[102] Saída especial (ocorre quando o tipo do cartão é 100)

[191] Entrada liberada (ocorre quando o tipo do cartão é 99)

[192] Saída liberada (ocorre quando o tipo do cartão é 99)

(4) Acesso realizado

(5) Acesso não concluído

(6) Novo crachá

(7) Capturou crachá

(8) Alarme da leitora, veja as subcategorias

[901] Falha interna do leitor

[902] Falha interna do HandKey

[903] Intrusão

[904] Porta aberta

[905] Sem cartão para gravação

[906] Cartão não removido

[953] Fim de intrusão (fim do alarme)

[954] Fim de porta aberta (fim do alarme)

[956] Fim de cartão não removido (fim do alarme)

[911] Comunicação em estado anormal

[912] Dispositivo em estado anormal

[921] Comunicação em estado normal (retorno de comunicação)

[922] Dispositivo em estado normal (retomada da operação)

(9) Alarme da unidade remota, veja as subcategorias

[911] Comunicação em estado anormal

[912] Dispositivo em estado anormal

[921] Comunicação em estado normal (retorno de comunicação) 
[922] Dispositivo em estado normal (retomada da operação)

(10) Alarme da câmera, veja as subcategorias.

[911] Comunicação em estado anormal

[912] Dispositivo em estado anormal

[921] Comunicação em estado normal (retorno de comunicação)

[922] Dispositivo em estado normal (retomada da operação)

(11) Execução de comandos pelo operador

[1001] Colocar dispositivo em modo manual liberado

[1002] Colocar dispositivo em modo manual bloqueado

[1003] Colocar dispositivo em modo automático

[1004] Enviar lista de crachás

Os seguintes dados são gerenciados pelo Gestor de Eventos:

- evento_id: número serial que identifica o evento de forma única

- deviceid: assetid do dispositivo: pode ser uma leitora, uma unidade remota, uma câmera, etc.

- tipo: Tipo do evento conforme lista acima

- subtipo: Subcategoria conforme lista acima

- descrição: Descrição do evento, conforme lista acima ou um texto livre.

- crachaid: assetid do crachá

- zonaid entrada: assetid da zona de entrada

- zonaid saída: assetid da zona de saída

- timestamp: instante em que ocorreu o evento

- registrado em: instante quando o evento foi coletado pelo Gestor de Eventos

- gravidade: gravidade do evento, este dado é útil para manipulação e filtragem dos evento

- ack: flag que indica se o evento foi reconhecido por algum operador

- userid: operador que reconheceu o evento

- timestamp ack: instante em que o evento foi reconhecido 


\subsection{INTEGRAÇÃO SED COM SSPP.}

"Através do SED, as empresas enviam e recebem informações sobre as solicitações de emissão de crachá, as solicitações de vinculo de crachás préimpressos e dos pedidos de alteração dos crachás emitidos. Somente as empresas previamente autorizadas pela CODESP terão acesso a este serviço. Todas as solicitações, vínculos de crachá e pedidos de alteração, após o registro na SED, ficarão disponíveis para as Autoridades - CODESP, Alfândega e Policia Federal verificarem as informações podendo autorizar ou cancelar o(s) registro(s).

As empresas, com perfil Responsável, deverão estar cadastradas no banco de dados do SSPP e poderão, mediante acesso ao SED, efetuar as solicitações de emissão de crachás pela CODESP através de envio de arquivo de dados.

Para habilitar a transmissão de dados pela VAN, esta procederá, como parte de seu serviço, com a instalação de seu software comunicador tanto nos Responsáveis como no servidor do SSPP, para que assim se estabeleça o canal de comunicação para o tráfego de dados. Esse software estabelece a transferência de arquivos através da Internet, propiciando agilidade e eficiência nos serviços bem como a confiabilidade dos dados, uma vez que se elimina o trâmite de papéis. Ou seja, qualquer acesso à Internet permite que uma empresa utilize o serviço de VAN e troque dados com o SSPP.

É importante destacar também que, o software disponibilizado pelas VANs possui, geralmente, rotina própria de criptografia, conseqüentemente aumentando a segurança da transferência de dados.

Vale destacar também que, algumas VANs possuem serviços adicionais que podem agregar valor à usual transferência de dados de seus clientes. Um desses serviços é a conversão de formatos de mensagens, que elimina a necessidade de qualquer sistema de customização ou de tradução internos em um cliente, uma vez que é a VAN quem efetua a conversão do formato da mensagem do cliente para o formato exigido pelo SSPP, qualquer que seja o documento envolvido (solicitações de emissão de crachá, solicitações de vinculo de crachás pré-impressos, pedidos de alteração dos crachás emitidos, etc.)."24

\footnotetext{
${ }^{24}$ Cartilha do Controle de Acesso nas Áreas Restritas do Porto de Santos, disponível no sitio da SED em $<$ http://www.superviadedados.com.br/_ftp/sspp\%20v8_2_4.pdf>
} 
Quanto aos sistemas de controle de acesso (MDC3000), circuito fechado de televisão digital (SmartSight) e Supervia Eletrônica de Dados, possuem um bom nível de integração e visam a integridade dos dados, racionalização de procedimentos, agilidade e maiores facilidades operacionais.

\subsubsection{LIGAÇÃO COM OS TERMINAIS}

Os terminais, arrendatários de áreas no porto e também considerados como Responsáveis no SSPP serão tratados de forma diferenciada no tocante ao controle de acesso. Inicialmente, como seus sistemas de acesso não estarão interligados ao SSPP, os terminais deverão informar a CODESP a respeito de todo fluxo de entradas e saídas de pessoas e veículos de suas dependências, utilizando para isso, o canal de transações eletrônicas disponibilizado pela SED. Desta forma, os terminais poderão utilizar o serviço de VAN para envio de seus registros, ou caso seja de sua preferência, é permitido também o uso do site do SSPP.

Por definição e exigência da CODESP, os terminais devem enviar os registros de acesso de pessoas e veículos em suas dependências logo após ter ocorrido o evento de entrada ou de saída. Será tolerado, no máximo, um atraso de 10 minutos entre o instante da entrada ou da saída do Usuário no local de acesso do terminal e o instante de recebimento do arquivo de dados correspondente ao evento em questão.

Vale destacar que, em qualquer acesso à zona primária é exigido o credenciamento junto a CODESP; em virtude disso, os terminais devem solicitar crachás de acesso a CODESP para todos os seus funcionários ou prestadores de serviços, e seus respectivos veículos, que, por ventura, necessitem ter acesso à zona primária. Portanto, caso não haja autorização de acesso para determinada pessoa ou veículo, o arquivo de dados associado ao registro de entrada ou saída dessa pessoa ou veículo não poderá ser aceito pelo SSPP.

As respostas às solicitações de acesso bem como a Lista Negra e a lista de cartões válidos poderão ser recebidas pelos terminais através da SED ou serem consultadas pelo site do SSPP. 
No ANEXO J, é apresentada a especificação dos dados que deverão trafegar através da SED via arquivo de dados, tanto para uso dos terminais como para uso de outros Responsáveis que optem por este meio.

\subsection{PLANO NACIONAL DE SEGURANÇA ADUANEIRA (PNSA)}

O projeto que esta sendo elaborado na administração central da Secretaria da Receita Federal (SRF), que dentro das suas atribuições e competência aprimorará técnicas que com aquisição de novos equipamentos e controles que contribuirão para impedir a prática de contrabando, pirataria, tráfico de armas ou drogas, saída ilegal de divisas e prevenir atitudes terroristas no transporte internacional, que a partir de sua implantação em caráter nacional junto com as informações advindas das atividades aduaneiras auxiliaram previamente a efetuar uma análise de risco aduaneiro antes mesmo da chegada dos veículos e passageiros, bem como do despacho das bagagens e cargas de importação ou exportação contribuindo de modo eficaz as novas exigências de segurança mundial. As medidas do Plano Nacional de Segurança Aduaneira - PNSA prevêem investimentos em equipamentos de inspeção de cargas e vigilância das áreas alfandegadas, como scanners, câmeras de vídeo e detectores de radiação dentre outros.

O PNSA terá como projeto piloto a Alfândega do porto de Santos na área portuária.

O projeto revisará os procedimentos existentes como implementará melhorias às condições de segurança aduaneira, como:

a) A reestruturação das instalações físicas das zonas primárias;

b) A disponibilidade de instalação de novos equipamentos de inspeção de cargas, veículos, bagagens e pessoas;

c) A utilização de equipamentos de segurança pessoal pelos servidores envolvidos nas operações correlatas;

d) O desenvolvimento de novos sistemas de informação da SRF, provendo, inclusive, a interligação com sistemas de empresas intervenientes e de outros 
órgãos, mediante a celebração de convênios, de acordo com as necessidades.

Irá contar com uma Central de Operações e Vigilância - COV que receberá os dados sejam através de câmeras, pessoal qualificado ou sistemas informatizados como os de controle de monitoramento de pessoas e veículos, de informações provenientes do sistema de controle de cargas movimentadas na zona de vigilância aduaneira, a partir das quais auxiliaram o COV na tomada de ações como:

a) Ações com enfoque no controle de fluxo de pessoas;

b) Ações com enfoque no fluxo de bagagens;

c) Ações com enfoque no fluxo de veículos;

d) Ações com enfoque no fluxo de cargas.

As ações conduzidas sob o enfoque no controle de fluxo de pessoas normalmente são realizadas por alguns órgãos de controle que possuem interesses específicos segundo suas esferas de competência e atuações funcionais.

Como exemplo, temos a própria Autoridade Portuária, responsável pela organização e regulamentação da Guarda Portuária, e que administra as instalações de acesso (Gates) à zona portuária, a qual incumbe prover a segurança do porto, principalmente em atendimento às exigências do código internacional ISPS. Já a Polícia Federal visa, além do controle de imigração, a prevenção e repressão dos crimes praticados na área portuária, inclusive terrorismo com repercussão internacional.

Diante da diversidade de controles para um mesmo enfoque, torna-se razoável que as ações sejam realizadas conjuntamente ou que o agente responsável por conduzir uma ação notifique as demais autoridades competentes interessadas. 


\subsubsection{INTEGRAÇÃO DO SSPP PARA ATENDIMENTO DO PNSA}

A partir da instalação dos equipamentos no porto de Santos, pretende-se controlar todas as entradas e saídas de pessoas e veículos, além das operações de carregamento e descarga dos navios.

Desenvolver-se-á um centro de controle operacional localizado no prédio da Alfândega, semelhante ao CCCOM da CODESP, que estabelecerá a integração de dados dos sistemas, inclusive de acesso e de imagem de forma on-line entre a Alfândega, CODESP e os terminais Alfandegados. Portanto, em um futuro próximo, todos os sistemas da comunidade portuária estarão totalmente integrados ao sistema de vigilância a ser desenvolvido pela Alfândega, o que propiciará seu controle total sobre os acessos e as atividades exercidas no porto de Santos.

Em razão de a Alfândega exigir para o plano PNSA, informações de acesso, cargas e imagens on-line, a CODESP poderá estudar a possibilidade de conectividade através de seu backbone, para os terminais que assim o desejar, sob consulta previa. 


\section{CONCLUSÃO}

Os níveis de segurança de acordo com o ISPS Code implicam necessariamente em estabelecer melhorias da infra-estrutura administrativa e física, seja em equipamentos, tecnologia e na formação e capacitação de recursos humanos de tal forma que possam ser absorvidos por todos os atores da comunidade portuária como meio de assegurar a aplicação homogênea da nova norma de proteção portuária.

Esta é a primeira dissertação que tem como foco a segurança nos portos brasileiros. Uma das várias contribuições desta dissertação foi o entendimento das regras de segurança nacional (SSPP) e internacional (ISPS Code) que envolvem navios, instalações, autoridades e a comunidade portuária, tornando-se determinante para promover um estudo que avalia operacionalmente o modelo tecnológico adotado no porto de Santos.

Os subsistemas adotados pelo porto de Santos foram detalhados no texto e estão integrados e centralizados no CCOM com o objetivo de monitorar os acessos de pessoas e veículo nas áreas controladas, os quais auxiliam na tomada de decisão em tempo real, para a aplicação de ações de segurança dependendo do seu grau de risco.

A comunicação entre a Aduana e o porto de Santos através do Sistema de Segurança Pública Portuário (SSPP) e o Plano de Segurança Aduaneira Portuária (PSAP) quando da sua implantação é de suma importância no contexto segurança, pois tanto as fiscalizações portuárias quanto as aduaneiras poderão usar uma mesma base de dados para controle das atividades portuárias.

O porto de Santos, por ser o único porto com CSI, poderá embarcar contêineres originários de outros portos nacionais para portos americanos fazendo com que a movimentação de contêineres aumente e este porto se torne um ponto concentrador de carga.

O SSPP é um sistema pioneiro no Brasil, que além da segurança, contribui para monitoramento de cargas em cadeias logísticas, totalmente desenvolvido em Santos. Podemos dizer que nossa região também pode ser nacionalmente conhecida como uma referência em sistemas de gestão de segurança para operações portuárias e entrar no seleto grupo mundial que desenvolve esta tecnologia. Afinal, multiplicar sucessos como o do SSPP, potencializará os 
diferenciais no setor e manterá a hegemonia no fator segurança. Está aí, uma segunda etapa de crescimento, para além de outras fronteiras.

O código ISPS contará com Monitoração das Embarcações, via Sistema de Informação e Gestão de Tráfego - VTMIS, Sistema Automático de Identificação AIS, Sistema de Identificação e Acompanhamento de Navios a Longa Distância LRIT esse conjunto de proteção a navios colocará o porto numa condição antecipada de informações que ajudarão a prevenir uma situação de perigo ou para melhor gerir o porto quanto ao tráfico portuário.

Deve-se também considerar o programa que vem sendo desenvolvido pela Organização Mundial das Aduanas "World Customs Organization" - WCO que introduz o conceito de cadeia segura de transportes e do operador logístico certificado. Este programa visa estabelecer processos seguros de tal forma que carga que é inspecionada de um lado da fronteira não precisa ser inspecionada novamente no seu destino. Para tanto serão necessárias, cada vez mais, ferramentas como estas implementadas no porto de Santos integradas a ferramentas de inspeção não intrusiva de carga, bem como ferramentas de rastreamento e lacre eletrônico.

Diante deste conceito de cadeia segura de distribuição de logística integrada porta a porta há ainda muito a ser feito para tornar os portos integrados dentro do cenário globalizado das relações comerciais. 


\section{REFERÊNCIAS BIBLIOGRÁFICAS}

FONTANA, C. F. - Modelo de Automação de um sistema de Controle de Carga para a Aduana nos Portos Brasileiros; 2004. 129 p. Dissertação (Mestrado). Escola Politécnica. Universidade de São Paulo. São Paulo. 2005.

FREITAS, J. - CAP - Instrumento de Participação Democrática e de Desenvolvimento. São Paulo: Aduaneiras, 2005. 30 p.

GUANDALINI, G. A caixa que encolheu a terra. Como o Contêiner barateou o transporte e revolucionou o comércio mundial. São Paulo: Revista Veja. n.2002,.104-105. p. Abril 2007.

RUSSO FILHO, A. - Comércio internacional, um modelo para segurança portuária e modernização da Aduana brasileira. 2006. 122 f. Dissertação (mestrado). Escola Politécnica. Universidade de São Paulo. São Paulo. 2006.

KEEDI, S. e MENDONÇA, P. C. C. - Transportes e seguros no comércio exterior. 2. ed. São Paulo: Aduaneiras, 2000.

LEVISON, M. - The Box - How the Shipping Container Made the World Smaller and the World Economy Bigger. New York: Princeton University Press, 2006. 390 p.

OLIVEIRA, C. T. Modernização dos portos. 3. ed. São Paulo: Aduaneiras, 2000.

Outras referências consultadas na internet:

AGÊNCIA NACIONAL DE TRANSPORTES AQUAVIÁRIOS - ANTAQ. Ministério dos Transportes. Adoção do Código Internacional para a Proteção de Navios e Instalações Portuárias. Resolução 2 da Conferência. Brasília: 2003. Disponível em: <http://www.antaq.gov.br/NovositeAntaq/pdf/ISPSversaoportugues.pdf> Acesso em: 06 fev. 2007.

AGÊNCIA NACIONAL DE VIGILÂNCIA SANITÁRIA. Ministério da Saúde, Portos, Aeroportos e Fronteiras. Brasília: [ca. 2007]. Disponível em: $<$ http://www.anvisa.gov.br/paf/portos/embarcacoes.htm> Acesso em: 27 jul. 2007 
BRASIL. Decreto n. 1.507, de 30 de maio de 1995. Cria a Comissão Nacional de Segurança Pública nos Portos, Terminais e Vias Navegáveis, e dá outras providências. Brasília: 1995. Sitio da Presidência da República. DOU de 31/05/1995 Disponível em: < <http://www.planalto.gov.br/ccivil 03/Decreto/1995/D1507.htm> Acesso em: 23 ago. 2006

BRASIL. Decreto n. 1.972, de 30 de julho de 1996. Altera a redação do art. $2^{\circ}$ do Decreto $\mathrm{n}^{\circ}$. 1.507, de 30 de maio de 1995, que cria a Comissão Nacional de Segurança Pública nos Portos, Terminais e Vias Navegáveis, e dá outras providências. Brasília: 1996. Sitio da Presidência da República. DOU de 31/07/1996 Disponível em: <http://www.planalto.gov.br/ccivil 03/Decreto/1996/D1972.htm> Acesso em: 23 ago. 2006

BRASIL. Lei n. 8.630, de 25 de fevereiro de 1993. Lei de Modernização dos Portos. Dispõe sobre o Regime Jurídico da Exploração dos Portos Organizados e das instalações Portuárias e dá outras providências. Sitio da Presidência da República. DOU de 26/02/1993. Disponível em: <http://www.planalto.gov.br/ccivil/leis/L8630.htm>. Acesso em 12 mar. 2006.

BRASIL. Medida Provisória n. 369 de 7 de maio de 2007. Acresce e altera dispositivos da Lei no 10.683, de 28 de maio de 2003, para criar a Secretaria Especial de Portos, e dá outras providências. DOU de 08/05/2007. Sitio da Presidência da República. Disponível em:

$<$ http://legislacao.planalto.gov.br/legisla/legislacao.nsf/fraWeb?OpenFrameSet\&Fram $\mathrm{e}=$ frmWeb2\&Src=\%2Flegisla\%2Flegislacao.nsf\%2FViw Identificacao\%2Fmpv\%252 0369-2007\%3FOpenDocument\%26AutoFramed> Acesso em 25 jun. 2007.

BRASIL. Resolução - RDC n. 217, de 21 de novembro de 2001. Agência Nacional de Vigilância Sanitária, Ministério da Saúde, D.O. 21/12/2001 Disponível em: <http://www.anvisa.gov.br/legis/resol/2001/217 01rdc.htm> Acesso em: 27/07/2007

BAUMGARTEN, M. Z. Impacto da Lei $\mathbf{n}^{\circ} \mathbf{8 . 6 3 0 / 9 3}$ nas dinâmicas portuárias e relações internacionais brasileiras. Teresina, Jus Navigandi, ano 10, n. 1118, 24 jul. 2006. Disponível em: <http://jus2.uol.com.br/doutrina/texto.asp?id=8674 >. Acesso em: 13 fev. 2007.

COMISSÃO NACIONAL DE SEGURANÇA PÚBLICA NOS PORTOS, TERMINAIS E VIAS NAVEGÁVEIS - CONPORTOS. Ministério da Justiça. Plano Nacional de Segurança Pública Portuária. $1^{a}$ ed. Brasília: [s.n.], 2002, 23 p. Disponível em: $<$ http://www.portoriogrande.com.br/pt/servicos/Plano Nacional Portuario.pdf> Acesso em 06 fev. 2006. 
COMISSÃO NACIONAL DE SEGURANÇA PÚBLICA NOS PORTOS, TERMINAIS E VIAS NAVEGÁVEIS - CONPORTOS. Ministério da Justiça, Defesa (Marinha do Brasil), Fazenda, Relações Exteriores e Transportes. Instalações Portuárias "Status" ALFA por Estado. Brasília: 2007. Disponível em:

<http://www.mj.gov.br/services/DocumentManagement/FileDownload.EZTSvc.asp?D ocumentID=\%7B6036C42A-5846-4AC9-9EE8-

34CDC68CB5E9\%7D\&ServicelnstUID=\%7BB78EA6CB-3FB8-4814-AEF6-

31787003C745\%7D > Acesso em: 28 Ago. 2007.

COMPANHIA DOCAS DO ESTADO DE SÃO PAULO. Cartilha do Controle de Acesso nas Áreas Restritas do Porto de Santos. Santos: 2005. Disponível em: < http://www.superviadedados.com.br/ > Acesso em: 11 jan. 2006.

COMPANHIA DOCAS DO ESTADO DE SÃO PAULO. Porto de Santos. Informações e Dados Estatísticos sobre o Porto de Santos, relatórios gerenciais da Cia. Docas do Estado de São Paulo - CODESP. Santos: 2007. Disponível em: <http://www.portodesantos.com.br/authority/estatistica.html>. Acesso em: 06 fev. 2007.

COMPANHIA DOCAS DO ESTADO DE SÃO PAULO. Porto de Santos: Realizações em 2006 e Perspectivas para 2007. Santos: 2006. Disponível em: $<$ http://www.portodesantos.com/releases/arquivo2/0237.html> Acesso em: 22 ago. 2007.

CONSELHO DE AUTORIDADE PORTUÁRIA DO PORTO DE SANTOS - CAP Porto de Santos. São Deveres e Responsabilidades dos Operadores Portuários. Santos: 1993. Disponível em: <http://www.portodesantos.com/cap/deveres.html>. Acesso em: 30/05/2007

CUNHA, E.A.R.M. SISTRAM: A Evolução de um Sistema de Apoio ao SAR para uma Ferramenta de C $^{2}$ I. Brasília: Revista Passadiço da Marinha do Brasil, 2006, 16 p. Sítio Oficial Marinha do Brasil, Ministério da Defesa. Disponível em:

< http://www.mar.mil.br/caaml/passadico/2006/06sistram.pdf> Acesso em: 13 jun. 2006 
DELFAUD, P. (Org.). A Segurança do Transporte e do Tráfego Marítimo de Mercadorias. [S.I.], Rede Transnacional Atlântica, maio 2005. 98 p. Sítio da Rede Transnacional Atlântica dos Parceiros Econômicos e Sociais. Disponível em: $<$ http://www.rta-atn.org/documents/etudes/rtaatnsegurancadotransportemaritimo pt.pdf> Acesso em $06 \mathrm{fev} .2007$

DIOGO, L.M.G.C.; GOUVEIA, J.A.V. O Código ISPS e os novos caminhos da Segurança nos navios e portos. Portugal: 2005. Revista da Armada, $n^{\circ}$. 383, Ano XXXVI, FEV 2005.2 Disponível em: $<$ http://www.marinha.pt/extra/revista/ra fev2005/pagina fich tec.html $>$ Acesso em jan.2006

DIRETORIA DE PORTOS E COSTAS. Marinha do Brasil. Normas da Autoridade Marítima para Operação de Embarcações estrangeiras em Águas Jurisdicionais Brasileiras NORMAM-04/DPC. Capítulo 3 - Controle de Navios pelo Estado do Porto. Brasília: 2003. Disponível em:

< https://www.dpc.mar.mil.br/normam/N 04/N04cap3.pdf> Acesso em: 02 jun. 2007

DIRETORIA DE PORTOS E COSTAS. Marinha do Brasil. Normas da Autoridade Marítima para Trafego e Permanência de Embarcações em Águas Jurisdicionais Brasileiras. NORMAM-08/DPC. Capítulo 1 - Tráfego de Embarcações. Sistema de Identificação e acompanhamento de Navios a longa distância - LRIT. Brasília: 2007. Disponível em: $<$ https://www.dpc.mar.mil.br/normam/N 08/N08 Anexo 1C \%20Mod6.pdf> Acesso em: 02 jun. 2007

MARCHETTI, D.S.; PASTORI, A. Dimensionamento do Potencial de Investimentos para o Setor Portuário. Rio de Janeiro, BNDES Setorial, 2006, n. 24, 3-34 p. Disponível em: $<$ http://www.bndes.gov.br/conhecimento/bnset/set2401.pdf> Acesso em: 06 fev. 2007

NASCIMENTO, S.S. A Logística do Comércio Exterior Brasileiro.

[S.I.:s.n.], [2007]. Sítio do Guia Logística e Transporte. Disponível em: <http://www.guiadelogistica.com.br/Y661.htm> Acesso em: 21 ago. 2007

NOBREGA, C.A.W., NANKANI G.T. A Reforma Portuária Brasileira. Ministério dos Transportes. Brasília: Setembro 2001. Disponível em: $<$ http://www.geipot.gov.br/estudos realizados/Reforma Portuaria relfinal.doc > Acesso em: 06 fev. 2007. 
OLIVEIRA, C.C. O processo de modernização dos portos brasileiros na década de 90. 2007. 168 p. Dissertação (Mestrado) - Instituto de Economia. Universidade Estadual de Campinas, Campinas, 2000. Disponível em: <http://libdigi.unicamp.br/document/?code=vtls000225595 > Acesso em: 5 jan. 2007.

\author{
ORGANIZAÇÃO EUROPÉIA DE PORTOS MARÍTIMOS. Política de Portos \\ Marítimos. Bruxelas: Novembro 2004. Disponível em: \\ $<$ http://www.espo.be/downloads/archive/ebed326a-c10a-445a-8b5e- \\ 459aebfb8a47.pdf>. Acesso em: 06 fev. 2007.
}

ORGANIZAÇÃO MARÍTIMA INTERNACIONAL - IMO. IMO Assembly elects new Council for 2006-2007 biennium. Londres, 2005. Disponível em: $<$ http://www.imo.org/dynamic/mainframe.asp?topic id=1018\&doc id=5434>

Acesso em: 27 jun. 2007

ORGANIZAÇÃO MARÍTIMA INTERNACIONAL - IMO. AIS Transponder. Londres: [s.n.]. Disponível em:

$<$ http://www.imo.org/Safety/mainframe.asp?topic id=754> Acesso em: 06 jan. 2006

ORGANIZAÇÃO MARÍTIMA INTERNACIONAL - IMO. Long Range Identification and Tracking (LRIT). Londres: Maio 2006.

Disponível em: <http://www.imo.org/Safety/mainframe.asp?topic id=905>

Acesso em: 06 jan. 2006

PINTO, J.R.A.; ROCHA, A.J.R.; SILVA, R.D.P. (Org). O Brasil no Cenário Internacional de Defesa e Segurança. Brasília: Ministério da Defesa, Secretaria de Estudos e de Cooperação, 2004. 212p. - (Pensamento Brasileiro sobre Defesa e Segurança; v.2). Disponível em: < https://www.defesa.gov.br/colecao/brasil.pdf>. Acesso em 06 fev. 2007.

SALES, A. A Economia da Segurança. Para continuar prosperando no comércio internacional em meio a uma sucessão de novas ameaças e regulamentações, grandes exportadores investem na via da gestão integrada de riscos. [S.I.]: Revista Mundo Corporativo, ano 4, $\mathrm{N}^{\circ} .12,2^{\circ}$ trimestre de 2006, 18-20 p. Disponível em: <http://www.deloitte.com/dtt/cda/doc/content/Mundocorporativo12.pdf $>$ Acesso em: 15 set. 2006. 
SALOMÃO,S. Uma decisão sem erros. Brasília: Correio Braziliense, 2004. Disponível em:

< http://clipping.planejamento.gov.br/Noticias.asp?NOTCod=168732>. Acesso em: 18 jul. 2006.

U.S. CUSTOMS AND BORDER PROTECTION. U.S. Government. Container Security Iniciative - 2006 - 2011 Strtegic Plan. Estados Unidos: Agosto 2006 Disponível em: $<$ http://www.cbp.gov/linkhandler/cgov/border security/international activities/csi/csi s trategic plan.ctt/csi strategic plan.pdf>. Acesso em 24 nov. 2006.

ZIMMERMANN, P. Brito promete diagnóstico e novos diretores para portos de Santos e RJ. Brasília : FOLHAONLINE, 2007 disponível em: <http://www1.folha.uol.com.br/folha/dinheiro/ult91u117210.shtml>

Acesso em: 16 jul. 2007. 
ANEXO A

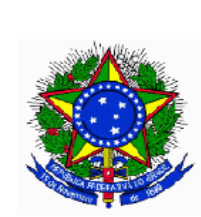

\section{MINISTÉRIO DA JUSTIÇA COMISSÃO NACIONAL DE SEGURANÇA PÚBLICA NOS PORTOS, TERMINAIS E VIAS NAVEGÁVEIS - CONPORTOS}

\section{PLANO NACIONAL \\ DE SEGURANÇA PÚBLICA PORTUÁRIA}

- $1^{\text {a }}$ Edição -

BRASÍLIA

Dezembro 2002 


\section{CAPÍTULO I}

\section{MISSÃO, COMPOSIÇÃO E ATRIBUIÇÕES DA CONPORTOS}

Referência: Decreto n 1.507, de 30 de maio de 1995.

\section{MISSÃO}

A Comissão Nacional de Segurança Pública nos Portos, Terminais e Vias Navegáveis (CONPORTOS) deverá elaborar e implementar o sistema de prevenção e repressão a atos ilícitos nos portos, terminais e vias navegáveis.

\section{COMPOSIÇÃO}

A CONPORTOS é integrada por um representante e respectivo suplente de cada Ministério a seguir indicado:

a. da Justiça, que a presidirá;

b. da Defesa (Comando da Marinha);

c. da Fazenda;

d. das Relações Exteriores; e

e. dos Transportes.

\section{ATRIBUIÇÕES}

\section{Compete à CONPORTOS:}

a. baixar normas, em nível nacional, sobre segurança pública nos portos, terminais e vias navegáveis; 
b. elaborar projetos específicos de segurança pública nos portos, terminais e vias navegáveis e, por via diplomática, buscar, junto à Organização Marítima Internacional (IMO), assistência técnica e financeira de países doadores e instituições financeiras internacionais;

c. apresentar sugestões às autoridades competentes para o aperfeiçoamento da legislação pertinente, inclusive consolidação de leis e regulamentos;

d. avaliar programas de aperfeiçoamento das atividades de segurança pública nos portos, terminais e vias navegáveis;

e. manter acompanhamento estatístico dos ilícitos penais ocorridos nos portos, terminais e vias navegáveis e dos resultados das investigações e das punições aplicadas;

f. encaminhar aos órgãos competentes avaliações periódicas sobre as necessidades relativas à segurança pública nos portos, terminais e vias navegáveis;

g. elaborar seu regimento interno e atualizá-lo, quando necessário, submetendo-o à aprovação do Ministro de Estado da Justiça;

h. criar e instalar Comissões Estaduais de Segurança Pública nos Portos, Terminais e Vias Navegáveis, fixando-lhes as atribuições;

i. orientar as Comissões Estaduais, no que for cabível;

j. gerenciar crises, relativas à segurança pública, quando necessário, em apoio às CESPORTOS. 


\section{CAPÍTULO II}

\section{MISSÃO, COMPOSIÇÃO E ATRIBUIÇÕES DAS CESPORTOS E DE SEUS INTEGRANTES}

Referência: Decreto $n^{0}$ 1.507, de 30 de maio de 2002-08-21

\section{MISSÃO}

As Comissões Estaduais de Segurança Pública nos Portos, Terminais e Vias Navegáveis (CESPORTOS) deverão prevenir e reprimir os atos ilícitos nos portos, terminais e vias navegáveis.

\section{COMPOSIÇÃO}

Cada CESPORTOS será composta, no mínimo, por representantes dos seguintes órgãos:

a. Departamento de Polícia Federal, que a coordenará;

b. Capitania dos Portos;

c. Secretaria da Receita Federal;

d. Administração portuária; e

e. Governo do Estado.

\section{ATRIBUIÇÕES}

\section{a. Compete às CESPORTOS:}

- de acordo com a CONPORTOS, baixar normas, em nível estadual, sobre segurança pública nos portos, terminais e vias navegáveis;

- elaborar estatísticas dos ilícitos penais ocorridos nos portos, 
terminais e vias navegáveis e dos resultados das investigações e das punições aplicadas;

- elaborar seu regimento interno e plano de segurança portuária a ser submetido à CONPORTOS;

- controlar os pontos sensíveis de valor estratégico, nas áreas portuárias;

- constituir, de acordo com a necessidade, subcomissões em cada instalação portuária do Estado;

- realizar anualmente, até 30 de setembro, planejamento das atividades da Comissão, para o ano seguinte, articulando com os órgãos representados a inclusão dos respectivos recursos orçamentários necessários, observada a programação específica de cada organização e encaminhar o referido planejamento à CONPORTOS;

- encaminhar, aos órgãos competentes, as avaliações periódicas sobre as necessidades relativas à segurança pública nos portos, terminais e vias navegáveis;

- manter estreito relacionamento com os representantes do Programa de Harmonização das Atividades dos Agentes de Autoridades nos Portos - PROHAGE;

- propor alteração na legislação, justificando as propostas;

- solicitar o apoio da CONPORTOS no gerenciamento de crises, relativas à segurança pública, quando julgar-se insuficiente para tal. 


\section{b. Compete aos órgãos que compõem as CESPORTOS:}

\section{1) Departamento de Polícia Federal}

De acordo com o a Instrução Normativa $n^{\circ} 2$, de 21 de julho de 1999, compete, à Polícia Federal, por meio dos Núcleos Especiais de Polícia Marítima (NEPOM), o seguinte:

- prevenir e reprimir os crimes praticados a bordo, contra ou em relação a embarcações atracadas no porto ou fundeadas nas adjacências ou no mar territorial brasileiro;

- prevenir e reprimir os crimes de competência da Polícia Federal praticados na área portuária, adjacências e no mar territorial brasileiro, incluindo o tráfico de armas de fogo, de pessoas, armas químicas, nucleares, biológicas e congêneres

e o terrorismo e outros crimes praticados no âmbito marítimo que tenham repercussão interestadual ou internacional e que exijam repressão uniforme;

- executar a fiscalização de migração de passageiros e tripulantes, quando da realização da visita oficial a bordo das embarcaçõesde transporte marítimo internacional, sem prejuízo de outras providências de controle interno em relação ao cumprimento do Estatuto do Estrangeiro, nos navios afretados ou não, que estejam operando em cabotagem, em apoio marítimo ou em apoio portuário, observando-se o recolhimento das taxas devidas;

- Fiscalizar as embarcações que operam no transporte internacional de cargas e/ou de passageiros, por meio da expedição de passes de entrada e de saída, em cada porto 
habilitado para o transporte internacional, ressalvando-se as atribuições dos demais órgãos;

- manter uma central de comunicação com rádio, telefone, fax e "e-mail", operando 24 horas, para receber denúncias de prática de ilícitos de competência da Polícia Federal nos portos e mar territorial e, conforme o caso, adotar as medidas pertinentes;

- policiar a área portuária, mediante o patrulhamento sistemático marítimo e terrestre;

- buscar a integração dos órgãos que compõem a CESPORTOS, para uma ação mais coordenada na prevenção e repressão aos atos ilícitos.

\section{2) Capitania dos Portos}

De acordocoma Lei $n^{\circ}$ 9.537/1997, que dispõe sobre a Segurança do Tráfego Aquaviário, cabe à Marinha do Brasil, na condição de autoridade marítima, promover a implantação e execução deste dispositivo, com o propósito de assegurar a salvaguarda da vida humana e a segurança da navegação, no mar aberto e hidrovias interiores, e a prevenção da poluição ambiental por parte de embarcações, plataformas ou suas instalações de apoio. Abaixo, estão relacionados os outros instrumentos legais que atribuem competência à Marinha do Brasil sobre segurança e que, de alguma forma, podem ter reflexos sobre a segurança pública portuária:

- Constituição da República Federativa do Brasil - Art 142; 
- Lei Complementar no 97/1999 - dispõe sobre as normas gerais para organização, o preparo e o emprego das Forças Armadas;

- Decreto $n^{0}$ 1.265/1994 - aprova a Política Marítima Nacional;

- Decreto $n^{0}$ 1.052/1994 - dispõe sobre a direção civil do transporte marítimo em situações de tensão internacional ou guerra, e

- Decreto $n^{\circ} 3.897 / 2001$ - fixa as diretrizes para o emprego das Forças Armadas na garantia da Lei e de Ordem e da outras providências.

\section{3) Secretaria da Receita Federal}

A fiscalização e o controle sobre o comércio exterior, essenciais à defesa dos interesses fazendários nacionais, serão exercidos pelo Ministério da Fazenda. (Artigo 237 da Constituição Federal). Portanto, à Secretaria da Receita Federal (SRF) compete:

- dirigir, supervisionar, orientar, coordenar e executar os serviços de administração, fiscalização e controle aduaneiro, inclusive no que diz respeito a alfandegamento de áreas e recintos. (Decreto $n^{\circ} 3782$ de 05/04/2001, artigos $7^{\circ}$, incisos XVI e artigo 35 e Portaria do MF no 259 de 24/08/2001, artigo $1^{\circ}$, inciso XVI);

- participar, observada a competência específica de outros órgãos, nas atividades de repressão ao contrabando, ao descaminho e ao tráfico ilícito de entorpecentes e de drogas afins, e à lavagem de dinheiro. (Decreto $n^{\circ} 3782$ de 05/04/2001, artigos $7^{\circ}$, inciso XIX e artigo 35 e Portaria do MF $n^{\circ} 259$ de 24/08/2001, artigo $1^{\circ}$, inciso XIX); 
- cumprir e fazer cumprir a legislação que regula a entrada, a permanência e a saída de quaisquer bens ou mercadorias no País. (LEI DOS PORTOS - Lei nº 8.630 de 25/12/93, artigo 36, inciso I);

- fiscalizar a entrada, a permanência, a movimentação e a saída de pessoas, veículos, unidades decargae mercadorias,sem prejuízo das atribuições das outras autoridades no porto. (LEI DOS PORTOS - Lei $n^{\circ} 8.630$ de 25/12/93, artigo 36, inciso II);

- exercer a vigilância aduaneira e promover a repressão ao contrabando, ao descaminho e ao tráfico de drogas, sem prejuízo das atribuições de outros órgãos. (LEI DOS PORTOS - Lei $n^{\circ} 8.630$ de 25/12/93, artigo 36, inciso III);

- proceder ao despacho aduaneiro na importação e na exportação. (LEI DOS PORTOS - Lei no 8.630 de 25/12/93, artigo 36, inciso V);

- proceder à apreensão de mercadorias em situação irregular, nos termos da legislação fiscal aplicável. (LEI DOS PORTOS - Lei no 8.630 de 25/12/93, artigo 36, inciso VII);

- autorizar a remoção de mercadorias da área do porto para outros locais, alfandegados ou não, nos casos e na forma prevista na legislação aduaneira. ( LEI DOS PORTOS - Lei $n^{\circ}$ 8.630 de 25/12/93, artigo 36, inciso VIII);

- zelar pela observância da legislação aduaneira e pela defesa dos interesses fazendários nacionais. (LEI DOS PORTOS Lei $n^{\circ} 8.630$ de 25/12/93, artigo 36, inciso XI). 


\section{São, ainda, prerrogativas da SRF:}

1. A administração fazendária e seus servidores fiscais terão, dentro de suas áreas de competência e jurisdição, precedência sobre os demais setores administrativos, na forma da lei. (Constituição Federal 1988, artigo 37, inciso $\mathrm{XVII)}$

2. No exercício de suas atribuições, a autoridade aduaneira terá livre acesso a quaisquer dependências do porto e às embarcações atracadas ou não, bem como aos locais onde se encontrem mercadorias procedentes do exterior ou a ele destinadas, podendo, quando julgar necessário, requisitar papéis, livros eoutros documentos, inclusive, quando necessário, o apoio de força pública federal, estadual ou municipal. (LEI DOS PORTOS - Lei n 8.630 de 25/12/93, artigo 36 , parágrafo $2^{\circ}$ )

3. Em tudo o que interessar à fiscalização aduaneira na zona primária, a autoridade aduaneira tem precedência sobre as demais que ali exerçam suas atribuições.

$\S 1^{\circ}$ - O dispositivo neste item aplica-se igualmente à zona de vigilância aduaneira, devendo as demais autoridades prestar à autoridade aduaneira a colaboração que for solicitada.

$\S 2^{\circ}$ - A precedência de que trata este item implica, igualmente: 
I - a obrigação, por parte das demais autoridades, de prestar auxílio imediato, sempre que requisitado, para o cumprimento das atividades fiscais e de colocar à disposição da autoridade aduaneira pessoas, equipamentos ou instalações necessárias à ação fiscal;

II - que, no que interessar à Fazenda Nacional, a disciplina da entrada, permanência, movimentação e saída de pessoas, veículos, unidades de carga e mercadorias, na zona primária, é de competência da autoridade aduaneira, sem prejuízo das atribuições dos outros órgãos (Artigo 10 do Regulamento Aduaneiro, aprovado pelo Decreto $n^{\circ}$ 91030, de 05 de março de 1985 e Decreto Lei $n^{\circ}$ 37/66, Artigo 35).

4. A autoridade aduaneira poderá proceder às buscas em veículos necessárias para prevenir e reprimir a ocorrência de infração à legislação aduaneira, inclusive em momento anterior à prestação das informações referidas no caput. (Artigo 37, $\S 3^{\circ}$, do Decreto - Lei 37/66, alterado pela Medida Provisória $n^{\circ} 38$, de 14/05/2002).

\section{4) Administração Portuária}

À Administração Portuária, por meio de sua Guarda Portuária e consoante, também, com a Portaria $\mathrm{n}^{\circ} 180$, de 23 de maio de 2001, do Ministério dos Transportes, compete: 
- $\quad$ promover a vigilância e a segurança no porto organizado. $\mathrm{Na}$ zona primária do porto organizado, a vigilância será levada a efeito com o objetivo de garantir o cumprimento da legislação que regula a entrada, a permanência, a movimentação e a saída de pessoas, veículos, unidades de carga e mercadoria;

- $\quad$ prestar auxílio às autoridades que exerçam suas atribuições no porto, sempre que requisitada. Portanto, a Guarda Portuária deverá colaborar com os órgãos de segurança pública e demais autoridades que atuam na área portuária para manutenção da ordem e a prevenção de ilícitos no interior daquelas instalações;

- $\quad$ exercer o policiamento interno das instalações do porto;

- zelar pela segurança, ordem, disciplina e fiel guarda dos imóveis, equipamentos, mercadorias e outros bens existentes ou depositados na área portuária, sob a responsabilidade da administração portuária;

- deter, em flagrante delito, os autores de crimes ou contravenções penais e apreender os instrumentos e objetos que tiveram relação com o fato, entregando-os à autoridade competente;

- registrar a ocorrência, quando constatadas atividades ilícitas, acidentes de trabalho, sinistros ou avarias em equipamentos e veículos ou atividades irregulares que venham a prejudicar o andamento dos operações portuárias, mantendo a preservação do local do delito, efetuando os levantamentos preliminares e encaminhando-os à autoridade competente.

- adotar as seguintes providências, quando da ausência da autoridade competente, em caso de sinistro, acidente, crime, contravenção penal ou ocorrência anormal: 
$\sqrt{ }$ remover os feridos para o pronto-socorro ou hospital, comunicando, de imediato, o setor de segurança do trabalho;

$\sqrt{ }$ isolar o local para a realização de verificação e perícias, sempre que possível sem a paralisação das atividades portuárias;

$\sqrt{ }$ acionar o grupo de combate a incêndio, sempre que necessário.

- buscar a integração dos órgãos que compõem a CESPORTOS, para uma ação mais coordenada na prevenção e repressão aos atos ilícitos.

\section{5) Governo do Estado}

Ao Governo do Estado, por meio da Polícia Civil, Polícia Militar e Corpo de Bombeiros, de acordo com o Artigo 144 da Constituição da República Federativa do Brasil compete:

\section{a) Polícia Civil.}

- desempenhar as funções de polícia judiciária;

- apurar infrações penais, exceto as militares.

\section{b) Polícia Militar}

- realizar policiamento ostensivo;

- preservar a ordem pública.

\section{c) Corpo de Bombeiros}

- executar atividades de defesa civil, além das atribuições definidas em Lei. 
A Polícia Civil e a Polícia Militar deverão buscar a integração dos órgãos que compõem a CESPORTOS, para uma ação mais coordenada na prevenção e repressão aos atos ilícitos.

\section{c. Compete ao Coordenador da CESPORTOS:}

- exercer as atividades de secretaria executiva da CESPORTOS, oferecendo, inclusive, apoio administrativo durante a realização das reuniões ordinárias e extraordinárias da Comissão;

- convocar as reuniões ordinárias e, quando necessário, as extraordinárias da CESPORTOS;

- incentivar a ação integrada dos órgãos que compõem a CESPORTOS.

- elaborar e encaminhar à CONPORTOS, em até 15 (quinze) dias da realização, as atas das respectivas reuniões da CESPORTOS, após lida e aprovada;

- promover os atos necessários, perante as autoridades constituídas, à preservação da ordem pública e da incolumidade das pessoas e do patrimônio dos entes alcançados por esta norma;

- adotar as medidas necessárias, quando os atos de que trata o item anterior desta alínea "c" exigir a expedição de ordem judicial expressa que resguarde a ação a ser desencadeada;

- exercer outras atividades que Ihe sejam atribuídas, em razão da deliberação, no mínimo, da maioria dos membros que integram a CESPORTOS. 


\section{CAPÍTULO III}

\section{COMPROMISSOS}

COMPROMISSO No 1 - COMBATE AO NARCOTRÁFICO E AO CRIME ORGANIZADO NOS PORTOS, TERMINAIS E VIAS NAVEGÁVEIS.

\section{AÇÕES}

\section{OPERAÇÕES DE COMBATE AO NARCOTRÁFICO}

Desencadear nos portos do País operações integradas sistemáticas de repressão ao tráfico de drogas, a partir de uma atuação conjunta dos órgãos que compõem a CESPORTOS. Terão prioridade os portos dos estados de São Paulo, Rio de Janeiro, Pernambuco, Pará, Amazonas, Espírito Santo, Paraná, Rio Grande do Sul e Santa Catarina.

2. OPERAÇÕES DE COMBATE AO CONTRABANDO E AO DESCAMINHO.

Promover esforços conjuntos dos órgãos que compõem a CESPORTOS, para conter o contrabando e o descaminho de bens e valores nos portos, terminais e vias navegáveis.

\section{VIGILÂNCIA NOS PORTOS, TERMINAIS E VIAS NAVEGÁVEIS.}

Incrementar a vigilância nos portos, terminais e vias navegáveis, estabelecendo operações integradas inesperadas, a serem realizadas 
conforme orientação dos dados obtidos pelo Subsistema de Inteligência de Segurança Pública. Isto permitirá uma ação sistemática e planejada de repressão, além da otimização de recursos financeiros e humanos. A Marinha do Brasil faz as seguintes recomendações aos comandantes das embarcações, constantes do seguinte Decálogo:

- vigie o navio e a carga;

- ilumine o navio e seu costado;

- estabeleça comunicações para apoio externo;

- controle o acesso à carga e aos compartimentos habitáveis;

- mantenha as vigias fechadas;

- não deixe objetos de valor expostos;

- mantenha as escadas recolhidas;

- em caso de assalto soar alarme geral para a tripulação, manter iluminação adequada, soar alarme através do Canal 16 VHF para os navios nas proximidades e para o sistema de escuta permanente das autoridades em terra, soar alarmes sonoros intermitentes, visuais como holofotes e sinalizadores náuticos;

- mantenha os vigias contratados sob o controle do Oficial de Serviço;

- comunique à Polícia Federal qualquer ocorrência relativa a furto, roubo e assalto.

\section{CRIAÇÃO DOS NÚCLEOS ESPECIAIS DE POLÍCIA MARÍTIMA - NEPOM}

Criar sete Núcleos Especiais de Polícia Marítima - NEPOM, nas unidades do Rio Grande/RS, Itajaí/SC, Vitória/ES, Paranaguá/PR, Foz do Iguaçu/PR, Recife/PE e Belém/PA, como instrumento de combate ao roubo/furto em embarcações, ao narcotráfico e ao contrabando e 
descaminho, com a colaboração dos órgãos que compõem a CESPORTOS.

Resultados esperados 2003 - 2006

- Redução anual da entrada de drogas ilícitas no Brasil, através dos portos.

- Redução anual do contrabando e do descaminho através dos portos.

- Portos adequadamente controlados e vigiados.

- Operações de repressão ao crime mais integradas entre os órgãos que compõem a CESPORTOS.

COMPROMISSO No 2 - CONTROLE DE ENTRADA E SAÍDA DE ARMAS DO PAÍS.

\section{AÇÕES}

\section{INTENSIFICAÇÃO DA FISCALIZAÇÃO NOS PORTOS TERMINAIS E VIAS NAVEGÁVEIS}

Incrementar a fiscalização da entrada e saída de armas do País, com a participação integrada dos órgãos que compõem a CESPORTOS.

\section{RECOLHIMENTO DE ARMAS ILEGAIS}

Realizar ações de recolhimento de armas ilegais na posse de infratores, nos portos, terminais e vias navegáveis. 
Resultado esperado 2003 - 2006

- Redução de armas ilegais nas mãos de infratores, nos portos, terminais e vias navegáveis.

COMPROMISSO № 3 - REPRESSÃO AO ROUBO/FURTO DE CARGAS

AÇÃO

\section{OPERAÇÕES DE REPRESSÃO AO ROUBO/FURTO DE CARGAS}

Intensificar ações integradas de fiscalização, com vistas a diminuir os índices de roubo/furto de cargas em embarcações, "containers" e depósitos alfandegados.

Resultados esperados $2003-2006$

- Portos, terminais e vias navegáveis seguras.

- Ações integradas para o combate ao roubo/furto de cargas.

COMPROMISSO No 4 - UTILIZAÇÃO DO SUBSISTEMA DE INTELIGÊNCIA DE SEGURANÇA PÚBLICA

AÇÃO

8. INTEGRAÇÃO DAS CESPORTOS AO SUBSISTEMA DE INTELIGÊNCIA DE SEGURANÇA PÚBLICA

As CESPORTOS, por intermédio dos representantes dos órgãos que as compõem, deverão integrar-se ao Subsistema de Inteligência de 
Segurança Pública, utilizando os dados ali produzidos e, ao mesmo tempo, alimentando o referido Sistema.

\section{Resultados esperados $2003-2006$}

- Realizar ações integradas de segurança pública nos portos, terminais e vias navegáveis, orientadas pelo Subsistema de Inteligência de Segurança Pública. 
ANEXO B

\section{Solicitacão de Certificado}

\begin{tabular}{|l|l|l|}
\hline 01 & Livre Prática $\square$ & Desratização $\square$ \\
\hline
\end{tabular}

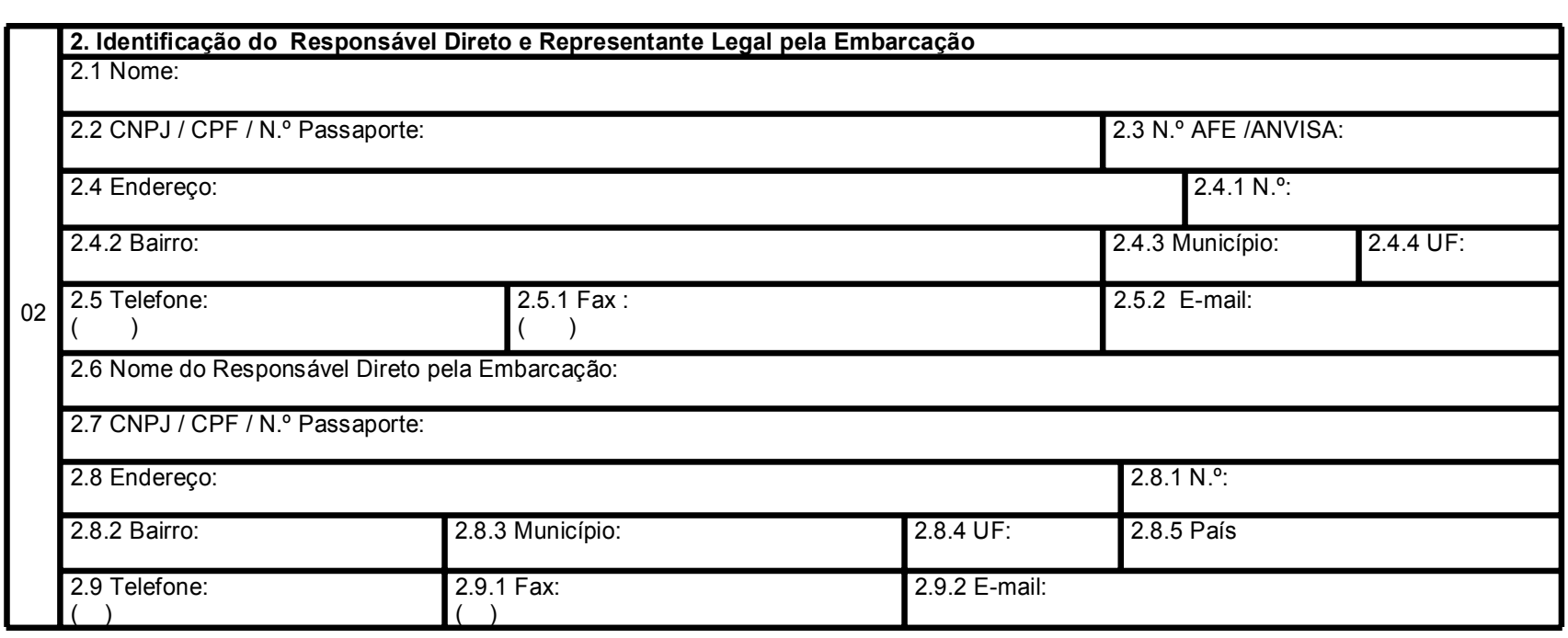

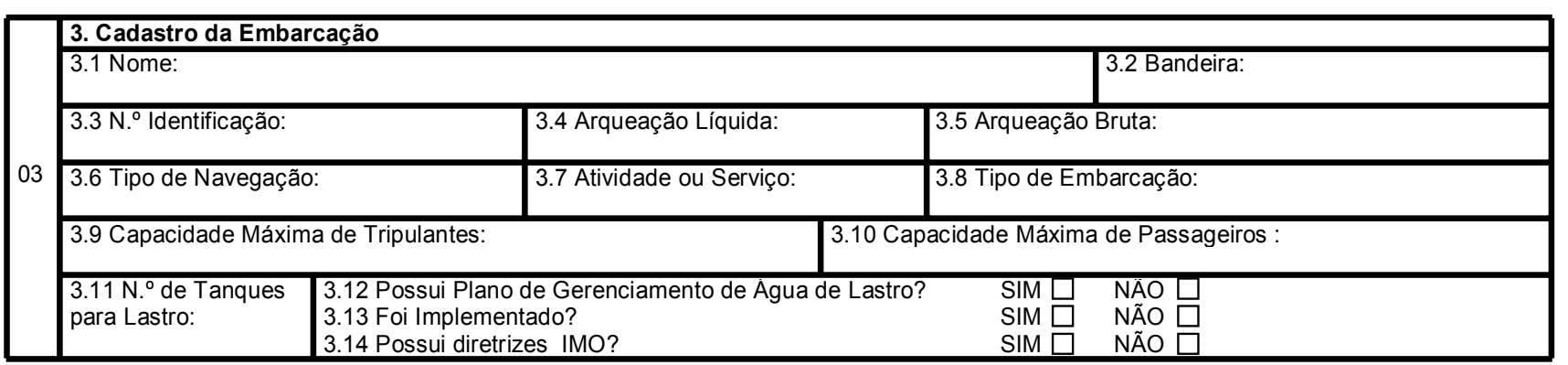

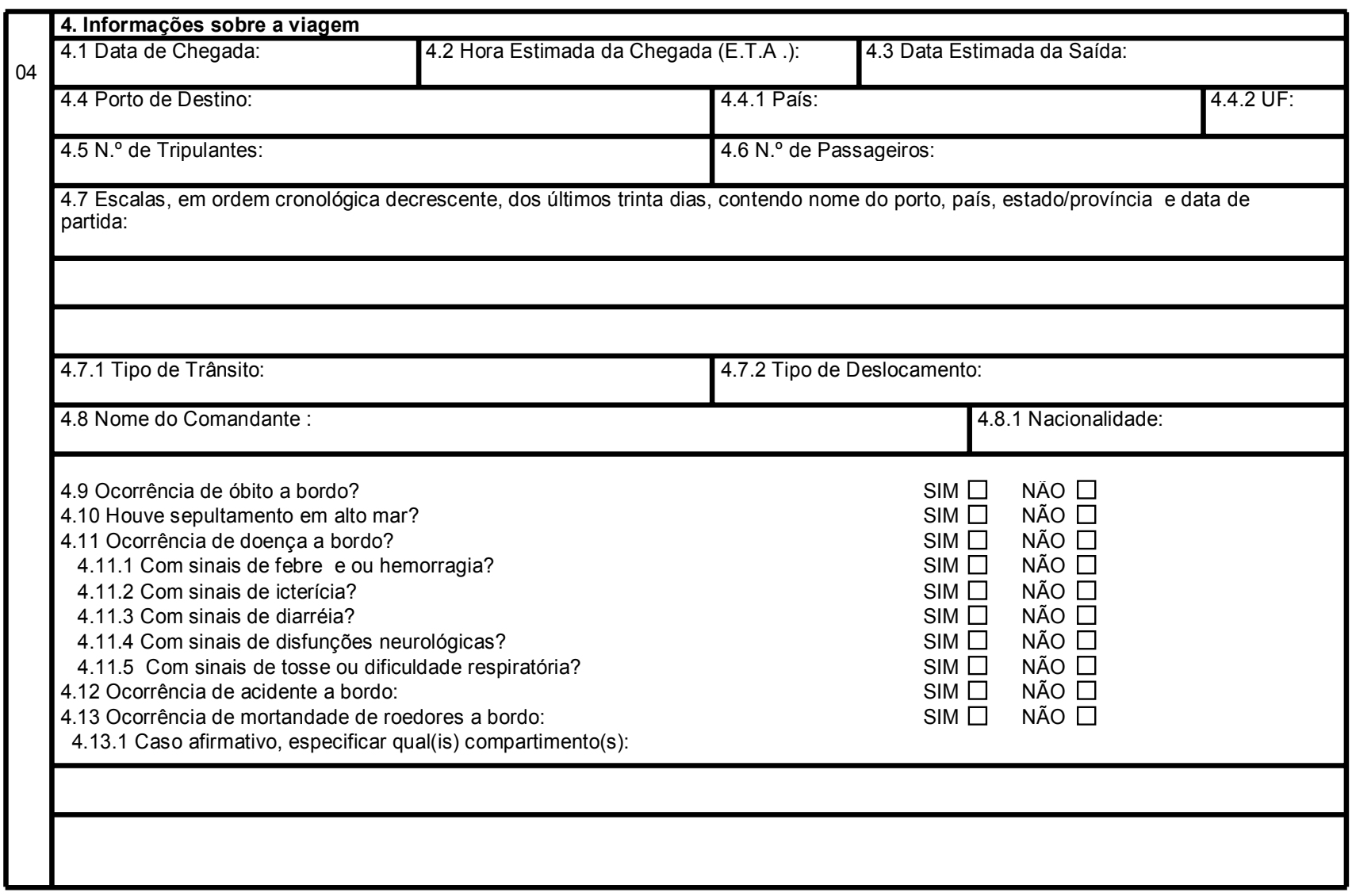


4.14.1 Porto Emissor:

4.15 Ocorrência de consumo de medicamento(s) durante a viagem: SIM $\square$ NAOO

4.15.1 Caso afirmativo, especificar o nome do(s) medicamento(s):

5. Preencher este quadro somente quando for o caso de solicitação do Certificado de Livre Prática

5.1 Produz água potável a bordo?

5.2 Porto onde ocorreu o último abastecimento de água potável:

5.3 Possui sistema de tratamento de água potável?

5.4 Capacidade máxima de armazenamento de áqua potável :

litro(s)
litro(s)

5.5 Possui água de lastro a bordo?

Longitude:

Latitude:

5.5.2 Foi efetuada substituição da água de lastro?

5.5.3 Local da substituicão:

Latitude:

5.5.4 Local do último deslastro:

05 Latitude:

5.5 .5 Haverá deslastro neste porto?

Longitude:

5.6 Possui tanque de retenção de efluentes sanitários?

5.6.1 Capacidade Máxima de armazenamento dos efluentes sanitários:

5.6.2 Autonomia de retenção, em função do $n .^{\circ}$ de viajantes a bordo:

5.7 Transporta carga perigosa?

5.8 Ocorrência a bordo de desinsetizacão/fumigacão de carga:

5.8.1 Caso afirmativo especificar o produto utilizado e data do procedimento:

Longitude

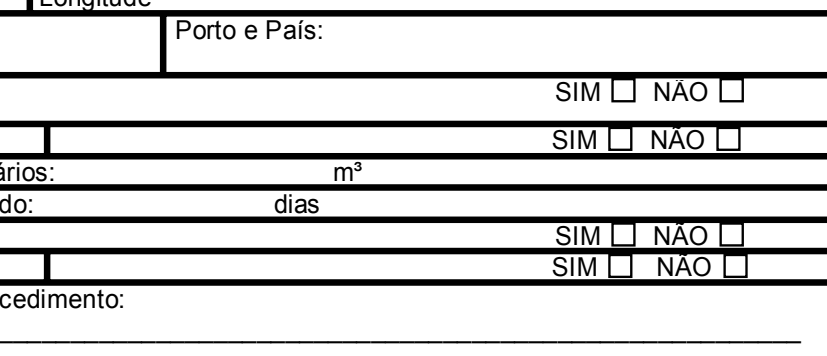

5.9 Taxa de Fiscalização Sanitária para Certificado de Livre Prática

$\square$ com isenção $\square$ sem isenção

5.9.2 Posto Portuário:

5.9.1 Data do depósito:

Porto e País

SIM $\square$ NÄO $\square$

SIM $\square$ NAO $\square$

SIM $\square$ NAO

6. Preencher este quadro somente quando for o caso de solicitacão do Certificado de Desratização ou Isencão de Desratizacão

6.1 Tipo de Certificado: $\square$ Nacional $\square$ Internacional

\begin{tabular}{ll|l}
06 & 6.2 Taxa de Fiscalização Sanitária: $\square$ com isenção $\square$ sem isenção & 6.2.1 Data do depósito:
\end{tabular}

6.2.2 Posto Portuário:

\begin{tabular}{|l|l|l|l|}
\hline \multicolumn{2}{|l|}{ 7. Identificação do Requerente } & 7.2 Data: & 7.3 CPF/Passaporte: \\
\cline { 2 - 4 } 07 & 7.1 Local: & 7.5 Assinatura: \\
\cline { 2 - 4 } & 7.4 Nome: & \\
\hline
\end{tabular}

\section{Recebimento pela Autoridade Sanitária}

$8.1 \mathrm{~N}^{\circ}$ da Solicitação de Certificado :

8.2 Data :

8.3 Hora :

08

8.4 Assinatura

8.5 Nome :

8.6 Matrícula: 
ANEXO C

MINISTERIO DA JUSTIÇA

COMISSÃO NACIONAL DE SEGURANÇA PÚBLICA NOS PORTOS, TERMINAIS E VIAS

NAVEGÁVEIS - CONPORTOS

ANEXO II

(RESOLUÇÃO Nº 12 - CONPORTOS)

\section{ROTEIRO PARA A ELABORAÇĀO E ANALISE DOS PLANOS DE SEGURANÇA PÚBLICA PORTUÁRIA - RPPS}

\begin{tabular}{l} 
INSTALAÇAO PORTUARIA: \\
EMPRESA: \\
ENDEREÇO: \\
CEP: \\
CNPJ: \\
\hline \hline OS: \\
(ORGANIZAÇÃO DE SEGURANÇA DE ELABOROU O PLANO)
\end{tabular}

1. INTRODUÇÃO (não precisa constar)

\section{ESTRUTURA}

\subsection{Folha de Rosto}

a. nome do trabalho (Plano de Segurança Pública Portuária - PSPP)

b. denominação social da instalação portuária.

c. mês e ano.

\subsection{Formatação}
a. papel A4,
b. textos em letra arial $n^{0} 12$
c. planilhas em letras de acordo com a necessidade
d. margem superior $=3,0 \mathrm{~cm}$
e. margem direita $=1,5 \mathrm{~cm}$
f. margem esquerda $=3,0 \mathrm{~cm}$
g. margem inferior $=1,5 \mathrm{~cm}$
h. numeração de página 


\subsection{Seqüência}
a. índice
b. aspectos legais
c. objetivo
d. identificação
e. metodologia
f. caracterização da instalação portuária
g. órgãos envolvidos e competências
h. fatores à serem considerados
i. área de atuação
j. análise situacional
k. procedimentos operacionais - conteúdo básico
I. formação e treinamento
m. auditorias e revisões
n. relatório conclusivo.
o. observações
p. anexos

\section{NORMAS A SEREM OBSERVADAS}

3.1. DECRETO 1.507 DE 30 DE MAIO DE 1995.

3.2. RESOLUÇÃO 02/2002 - CONPORTOS

3.3. RESOLUÇÃO 03/2003 - CONPORTOS

3.4. RESOLUÇÃO 04/2003 - CONPORTOS

3.5. RESOLUÇÃO 05/2003 - CONPORTOS (constar)

\subsubsection{Para os portos organizados:}

a. $\square$ Plano de Segurança Pública Portuária - PSPP do porto organizado que consolida os Planos de Segurança das instalações portuárias e de uso privativo, localizados na área do porto organizado, devidamente aprovados e anexados.

b. $\square$ cópia do voto e da ata da reunião da CESPORTOS que acolheu o PSPP.

\subsubsection{Para as instalações portuárias de uso privativo fora da área porto organizado:}

a. $\square$ cópia do voto e da ata da CESPORTOS que acolheu o PSPP.

\subsection{RESOLUÇÃO 09/2003 - CONPORTOS (constar)}

a. $\square$ cópia do comprovante da certificação expedida pela CONPORTOS, em favor da organização de segurança - OS.

b. $\square$ cópia do contrato de prestação de serviços firmado entre a contratante e a OS. 
c. $\square$ cópia dos comprovantes dos cadastramentos expedidos pela CONPORTOS, de todos aqueles que se envolveram, elaboraram e desenvolveram atividades relacionadas com os trabalhos, pela organização de segurança.

d. $\square$ cópia da Deliberação da CONPORTOS que aprovou o Estudo de Avaliação de Risco das Instalações Portuárias.

e. $\square$ O PSPP da instalação, no original, devidamente firmado pelos representantes legais da contratante, da OS e pelos responsáveis técnicos que o elaboraram.

3.7. RESOLUÇÃO 12/2003 - CONPORTOS (constar)

a. $\square$ o Termo de Referência para Análise e Aprovação dos Planos de Segurança Pública Portuária - TRPS.

\section{DESENVOLVIMENTO}

\subsection{OBJETIVO}

DE ACORDO COM O TRPS.

\subsection{IDENTIFICAÇÄO}

\subsubsection{Da instalação portuária}

\subsubsection{1. da instalação portuária}
a. $\square \quad$ nome e razão social
b. $\square$ endereço completo
c. $\square$ registros legais (CNPJ, Insc. estadual, Alvará e outro:
d. $\square$ telefone
e. $\square$ fax
f. $\square$ endereço eletrônico
g. $\square$ página na Internet (caso disponível)

\subsubsection{2. dos proprietários ou representantes legais}
a. $\square$ nome
b. $\square$ endereço completo
c. $\square$ registros legais (CPF, RG e outros
d. $\square$ telefone
e. $\square$ fax
f. $\square$ endereço eletrônico 


\subsubsection{3. do supervisor de segurança - SS}
a. $\square$ nome
b. $\square$ endereço completo
c. $\square$ registros legais (CPF, RG e outros
d. $\square$ telefone
e. $\square$ fax
f. $\square$ endereço eletrônico

4.2.2. da organização de segurança e dos técnicos responsáveis pela elaboração do PSPP

\subsubsection{1. organização de segurança - OS}
a. $\square$ nome e ou razão social
b. $\square$ endereço completo
c. $\square$ registros legais (CNPJ, Insc. estadual, Alvará e outros
d. $\square$ telefone
e. $\square$ fax
f. $\square$ endereço eletrônico.

\subsubsection{2. dos técnicos}
a. $\square$ nome
b. $\square$ endereço completo
c. $\square$ registros legais (RG, CPF, outros
d. $\square$ telefone
e. $\square$ fax
f. $\square$ endereço eletrônico

\subsection{METODOLOGIA}

a. $\square$ indicar a metodologia aplicada para elaboração do trabalho, de acordo com o item 4.3 do TRPS.

b. $\square$ informar se a metodologia atende ao disposto no ISPS Code.

\subsection{CARACTERIZAÇÃO DA INSTALAÇÃO PORTUARIA}
a. $\square \quad$ localização
b. $\square$ área física
c. $\square$ característica física da instalação
d. $\square$ áreas terrestres, acessos e cercanias
e. $\square$ áreas marítimas, acessos e cercanias
f. $\square$ representação gráfica (plantas, mapas ou croqui:
g. $\square$ outros 


\subsection{ORGAOOS ENVOLVIDOS E COMPETENCIAS}

Resolução 02/2002 - CONPORTOS - PLANO NACIONAL DE SEGURANÇA PÚBLICA PORTUÁRIA - PNSPP

DE ACORDO COM O TRPS.

4.6. FATORES A SEREM CONSIDERADOS

DE ACORDO COM O DISPOSTO NO ITEM 4.6 DO TRPS.

\subsection{AREAS DE ATUAÇĀO}

DE ACORDO COM O DISPOSTO NO ITEM 4.7 DO TRPS.

\subsection{ANALISE SITUACIONAL}

$\square$ DE ACORDO COM O DISPOSTO NO ITEM 4.8 DO TRPS.

\subsection{PROCEDIMENTOS OPERACIONAIS - CONTEUDO BASICO}

\section{DEFINIR:}

\subsubsection{Unidade de Segurança - US}
a. $\square$ estrutura organizacional e seu regimento interno
b. $\square$ atribuições da US e de seus elementos componentes
c. $\square$ deveres e responsabilidades dos funcionários da US
d. $\square$ parâmetros de desempenho de eficiência coletiva e individue
e. $\square$ procedimentos operacionais

\subsubsection{Proprietários, dirigentes e demais funcionários da instalação}
a. $\square$ deveres
b. $\square$ responsabilidades
c. $\square$ procedimentos operacionais

4.9.3. Sistema de cadastramento (de acordo com as diretrizes da CONPORTOS)
a. $\square$ do pessoal da US da instalação portuária
b. $\square$ dos proprietários, dirigentes e demais funcionários da instalação portuária
c. $\square$ das pessoas que eventualmente trabalhem, façam uso ou trafeguem nas instalação portuárias.


4.9.4. Normas de acesso (de acordo com as diretrizes da CONPORTOS)

a. $\square$ do pessoal da unidade de segurança da instalação portuária

b. $\square$ dos proprietários, dirigentes e demais funcionários da instalação portuária

c. $\square$ das pessoas que eventualmente trabalhem, façam uso ol trafeguem na instalação portuária

d. $\square$ de passageiros.

Obs: contemplar procedimentos para as áreas
a. $\square$ de acesso público
b. $\square$ de acesso controlado
c. $\square$ de acesso restrito

4.9.5. Sistema de cadastramento (de acordo com as diretrizes da CONPORTOS)
a. $\square$ de veículos (carga, particulares, transportadores e outro:
b. $\square$ de embarcações
c $\square$ de equipamentos
d. $\square$ de cargas em geral
e. $\square$ de mercadorias perigosas
f. $\square$ de substâncias nocivas

4.9.6. Normas de: (de acordo com as diretrizes da CONPORTOS)
a. $\square$ acesso de veículos (carga, particulares, transportadores e outros
b. $\square$ acesso de embarcações
c. $\square$ de entrada e saída de cargas
d. $\square$ de permanência de cargas
e. $\square$ de mercadorias perigosas
f. $\square$ de substâncias nocivas
g. $\square$ de utilização de estacionamento
h. $\square$ de permanência de veículos

Obs: contemplar procedimentos para as áreas
a. $\square$ de acesso público
b. $\square$ de acesso controlado
c. $\square$ de acesso restrito

\subsubsection{Procedimentos e registros:}

\subsubsection{1. movimentação}
a. $\square$ de veículos
b. $\square$ de embarcações
c. $\square$ de equipamentos
d. $\square$ de cargas em geral
e. $\square$ de mercadorias perigosas
f. $\square$ de substâncias nocivas
g. $\square$ outros 


\subsubsection{2. manuseio}
a. $\square \quad$ de veículos
b. $\square$ de embarcações
c. $\square$ de equipamentos
d. $\square$ de cargas em geral
:. $\square$ de produtos perigosos
f. $\square$ de substâncias nociva:
g. $\square$ outros

\subsubsection{3. armazenamento}
a. $\square \quad$ de equipamentos
b. $\square$ de cargas em geral
c. $\square$ de mercadorias perigosas
d. $\square$ de substâncias nocivas
e. $\square$ outros

4.9.8. Procedimentos para o controle, o acesso e detecção
a. $\square$ de armas
b. $\square$ de drogas
c. $\square$ artefatos explosivos
d. $\square$ de produtos perigosos
e. $\square$ substâncias nocivas
f. $\square$ outros

4.9.9. Procedimentos de acesso às informações
a. $\square$ cargas
b. $\square$ equipamentos
c. $\square$ pessoas envolvidas nos serviços da instalaçãc
d. $\square$ cronogramas de trabalho
:. $\square$ produtos perigosos
f. $\square$ substâncias nocivas
g. $\square$ incidentes de segurança
h. $\square$ pontos sensíveis
i. $\square$ vulnerabilidades
j. $\square$ informações de rotina
k. $\square$ informações confidenciais

\subsubsection{Procedimentos para proteção de informações}
a. $\square$ em meio físico
). $\square$ em meio eletrônico
c. $\square$ em meio magnético 


\subsubsection{Equipamentos e sistemas de segurança}
a. $\square$ processo para verificar a eficiência e a eficácia
b. $\square$ procedimentos para identificação de falhas
c. $\square$ procedimentos para resolução de falhas

\subsubsection{Procedimentos para controle das atividades de:}
a. $\square$ praticagem
b. $\square$ reboque
c. $\square$ abastecimento
d. $\square$ transporte de /material
e. $\square$ outros de apoio portuário.

\subsubsection{Procedimentos de integração operacional}
a. $\square$ da US da instalação portuária com as autoridades públicas envolvidas
b. $\square$ do Oficial de Segurança da embarcação que estiver no porto ou terminal com as autoridades públicas portuárias envolvidas.

\subsubsection{Sistemas de comunicação}

a. $\square$ entre as embarcações, as companhias de navegação, as US das instalações portuárias e a autoridade de segurança pública portuária local.

b. $\square$ entre o pessoal das US.

c. $\square$ entre os veículos terrestres e as US.

d. $\square$ entre a US das instalações portuárias de uso privativo fora da área do porto organizado e o Centro de Controle de Comunicação - CCCom do porto organizado

\subsubsection{Procedimento de comunicação}

a. $\square$ entre as embarcações, as companhias de navegação, as US das instalações portuárias e a autoridade de segurança pública local.

b. $\square$ entre o pessoal das US.

c. $\square$ entre os veículos terrestres e as US.

d. $\square$ entre a US das instalações portuárias de uso privativo fora do porto organizado e o CCCOM

e. $\square$ para manter as comunicações contínuas e eficazes.

f. $\square$ para sua proteção física.

g. $\square$ para a segurança da informação.

h. $\square$ para a coleta, classificação e armazenamento de dados.

i. $\square$ com os demais órgãos públicos e instituições. 


\subsubsection{Sinais de Alarme - SA das US}
a. $\square$ tipos de sinais de alarme - SA
b. $\square$ procedimentos
c. $\square$ meios
d. $\square$ canais de difusão

\subsubsection{Estabelecimento de níveis}

\subsubsection{Estabelecimento do Nível 2}
a. $\square$ medidas adicionais
b. $\square$ medidas operacionais
c. $\square$ medidas físicas
d. $\square$ possíveis implicações com a elevação do nível

OBS: Observar o contido na alínea "a" do parágrafo único do item 4.9.17 do TRPS.

\subsubsection{Estabelecimento do Nível 3}
a. $\square$ medidas adicionais
b. $\square$ medidas operacionais
c. $\square$ medidas físicas
d. $\square$ possíveis implicações com a elevação do nível

OBS: Observar o contido na alínea "b" do parágrafo único do item 4.9.17 do TRPS.

\subsubsection{Procedimentos para controle de movimentação navio/terra:}
a. $\square$ de tripulantes
b. $\square$ de profissionais não tripulantes
c. $\square$ de outras pessoas

4.9.19. Procedimentos para controle de armas de fogo
a. $\square \quad$ acesso às instalações
b. $\square$ porte
c. $\square$ guarda
d. $\square$ uso nas áreas das instalações portuária

\subsubsection{O comandante da embarcação deve:}
a. declarar estar ciente das normas de Segurança Pública a que se subordina
b. registrar a ocorrência de atos ilícitos no órgão policial competente;


c. encaminhar relatório circunstanciado sobre atos ilícitos ocorridos na embarcação à Autoridade de Segurança Portuária local.

d. firmar declaração da não ocorrência de tais atos, antes de deixar a instalação portuária brasileira. (em caso de não ocorrência)

\subsubsection{Relatório estatístico de llícitos Penais - RIP}

DE ACORDO COM AS ALÍNEAS DO PARÁGRAFO ÚNICO DO SUBITEM 4.9.21 DO TRPS.

\subsection{FORMAÇĀO E TREINAMENTO}

DE ACORDO COM O ITEM 4.10 DO TRPS.

\subsection{AUDITORIAS E REVISOES}

$\square$ DE ACORDO COM O ITEM 4.11 DO TRPS.

\subsection{RELATORIO CONCLUSIVO}

O relatório conclusivo deverá retratar, de forma abrangente e objetiva, resposta a todos os itens e subitens do TRPS e deste RTPS,

\section{OBSERVAÇOES}

5.1. Outros itens poderão ser abordados em razão das características de cada Porto Organizado ou Terminal de uso Privativo, sem desconsiderar a seqüência do roteiro de procedimentos retro-enumerados.

5.2. Independentemente deste roteiro de procedimentos, deverão ser observados todos os itens constantes do Termo de Referência para Elaboração e Análise dos Planos de Segurança Pública Portuária - Anexo I.

\section{ANEXOS}

6.1. Glossário

6.2. Normas

6.3. Plantas, mapas e croquis

6.4. Outros 
ANEXO D

DECLARAÇĀO DE PROTEÇĀO $n^{\circ}$ DECLARATION OF PROTECTION $n^{\circ}$

I (ano). - Folha $-1 / 2$

$I$ (year). - Page $-1 / 2$

(LOGOTIPO E NOME DA INSTALAÇĀO PORTUARIA)

DECLARAÇÃO DE PROTEÇÃO

DECLARATION OF PROTECTION

ANEXO DA RESOLUÇÃO No 33, DE 11 DE NOVEMBRO DE 2004. ANNEX OF THE RESOLUTION No 33 - NOVEMBER, $11^{\text {th }} / 2004$

$\mathrm{N}^{\circ} 0000 /$ (ano).

\begin{tabular}{||l|l|}
\hline Nome do Navio: Ship's Name: & \\
\hline Porto de Registro; Port of Registry: & \\
\hline$N^{\circ}$ IMO/Navio: IMO Number/Ship & \\
\hline Instalação Portuária: Port Installation: & \\
\hline$N^{\circ}$ IMO/Instalação: IMO Number/Installation: & \\
\hline
\end{tabular}

Esta DECLARACĀO DE PROTEÇĀO é válida a partir de....../..............até ......................., para as seguintes atividades: ..(listar as atividades incluindo os detalhes relevantes), sob os seguintes níveis de segurança:

This DECLARATION OF PROTECTION is valid from ............... Untill ............., to the following activities:........................................................................(to list the activities including the excellent details) under the following levels of protection:

\begin{tabular}{||l|l||}
\hline Nível de proteção para o navio: & \\
Protection level to the Ship: & \\
\hline $\begin{array}{l}\text { Nível de proteção para a instalação portuária: } \\
\text { Protection level to the Port Installation: }\end{array}$ & \\
\hline \hline
\end{tabular}

A Instalação Portuária e o Navio concordam com as seguintes medidas de segurança e responsabilidades para assegurar o cumprimento aos requisitos da Parte A do Código Internacional para a Proteção de Navios e Instalações Portuárias.

The Port Installation and the Ship agree to the following protection actions and responsibilities to assure the fulfillment to the requirements of the "A Part" of the International Ship and Port Security Code - ISPS.

A colocação das ASSINATURAS do Oficial de Proteção do Navio (SSO) e do Supervisor de Segurança da Instalação Portuária (PFSO) indica que a atividade será executada, de acordo com o Plano de Segurança da Instalação Portuária, aprovado pela Comissão Nacional de Segurança Pública nos Portos, Terminais e Vias Navegáveis - CONPORTOS.

The rank of the SIGNATURES of the Ship Security Officer (SSO) or Port Facility Security Officer (PFSO) of Port Installation in these columns indicates that the activity will be executed, in accordance with the approved Security Plan, by)

\begin{tabular}{|c|c|c|}
\hline $\begin{array}{c}\text { Atividade } \\
\text { Activity }\end{array}$ & $\begin{array}{l}\text { Instalação } \\
\text { Portuária } \\
\text { Port Installation }\end{array}$ & $\begin{array}{c}\text { Navio } \\
\text { Ship }\end{array}$ \\
\hline \multicolumn{3}{|l|}{$\begin{array}{l}\text { Assegurar a execução de todos os deveres relativos a proteção. } \\
\text { To Assure the execution of all protection duties. }\end{array}$} \\
\hline \multicolumn{3}{|l|}{$\begin{array}{l}\text { Monitorar áreas de acesso restrito para garantir que somente } \\
\text { pessoas autorizadas tenham acesso às mesmas. } \\
\text { To monitor restricted access areas to guarantee that only authorized people have } \\
\text { access to them. }\end{array}$} \\
\hline \multicolumn{3}{|l|}{$\begin{array}{l}\text { Controlar o acesso à Instalação Portuária. } \\
\text { To control the access to the Port Installation. }\end{array}$} \\
\hline $\begin{array}{l}\text { Controlar o acesso ao Navio. } \\
\text { To control the access to the Ship. }\end{array}$ & & \\
\hline
\end{tabular}

Assinado por, para e em nome - Assigned by, to or in name Instalação Portuária:

Port Installation:

Navio:

Ship: 


\begin{tabular}{|l|l|l||}
\hline $\begin{array}{l}\text { Monitorar a Instalação Portuária, incluindo áreas de atracação e } \\
\text { áreas em volta do Navio. } \\
\text { To monitor the Port Installation, including berthing areas and areas around the } \\
\text { Ship. }\end{array}$ & & \\
\hline $\begin{array}{l}\text { Manusear a carga. } \\
\text { To handle the cargo. }\end{array}$ & & \\
\hline $\begin{array}{l}\text { Assegura a entrega de provisões do Navio. } \\
\text { To assure the provision delivery to the Ship. }\end{array}$ & \\
\hline $\begin{array}{l}\text { Manusear a bagagem desacompanhada. } \\
\text { To handle the alone luggage. }\end{array}$ & \\
\hline $\begin{array}{l}\text { Controlar o embarque de pessoas e de seus pertences. } \\
\text { To control the embarkment of people and its belongings }\end{array}$ & \\
\hline $\begin{array}{l}\text { Assegurar que informações relativas à proteção estejam } \\
\text { prontamente disponíveis entre o Navio e a Instalação Portuária. } \\
\text { To assure that relative information to the protection are readily available between } \\
\text { the Ship and the Port Installation. }\end{array}$ & & \\
\hline \hline
\end{tabular}

As partes a este Acordo certificam que as medidas e ações relativas à segurança para a Instalação Portuária e para o Navio, tomadas durante as atividades especificadas, atendem às disposições do Capítulo XI-2 e da Parte A deste Código, as quais serão implementadas de acordo com as disposições já estipuladas em seu plano de segurança aprovado ou nos arranjos específicos acordados e descritos no anexo.

The parts to this Agreement certify that the relative measures and actions to the protection for the Port Installation and the Ship taken during the specified activities take care of to the disposals of Chapter XI-2 and the "A" Part of this Code, which will be implemented in accordance with the already stipulated disposals in its approved plan of protection or in the accorded and described specific arrangements in the annex.

Feito em

no dia

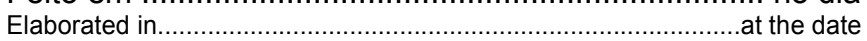

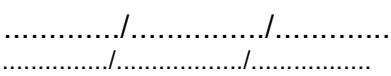

\begin{tabular}{||l|l||}
\hline Assinado por, para e em nome - Assigned by, to or in name \\
\hline Instalação Portuária: & $\begin{array}{l}\text { Navio: } \\
\text { Ship: } \\
\text { Port Installation: }\end{array}$ \\
& \\
\hline
\end{tabular}

\begin{tabular}{||l|l||}
\hline Nome e título da pessoa que assinou - Name e rank of who signed \\
\hline Nome: & Nome: \\
Name: & Name: \\
\hline Título: & Título: \\
Rank: & Rank: \\
\hline \hline
\end{tabular}

Dados para Contato (Contacts data)

(indicar os números de telefone, os canais de rádio e freqüências a serem utilizados, conforme apropriado - to indicate the numbers of telephone, the canals of radio and frequencies to be used, as appropriate)

\begin{tabular}{|l|l|}
\hline Da instalação portuária: & Do navio: \\
To the Port Installation: & To the Ship:
\end{tabular}




\section{ANEXO E}

\section{Distribuição dos Gates de Santos - Geral}

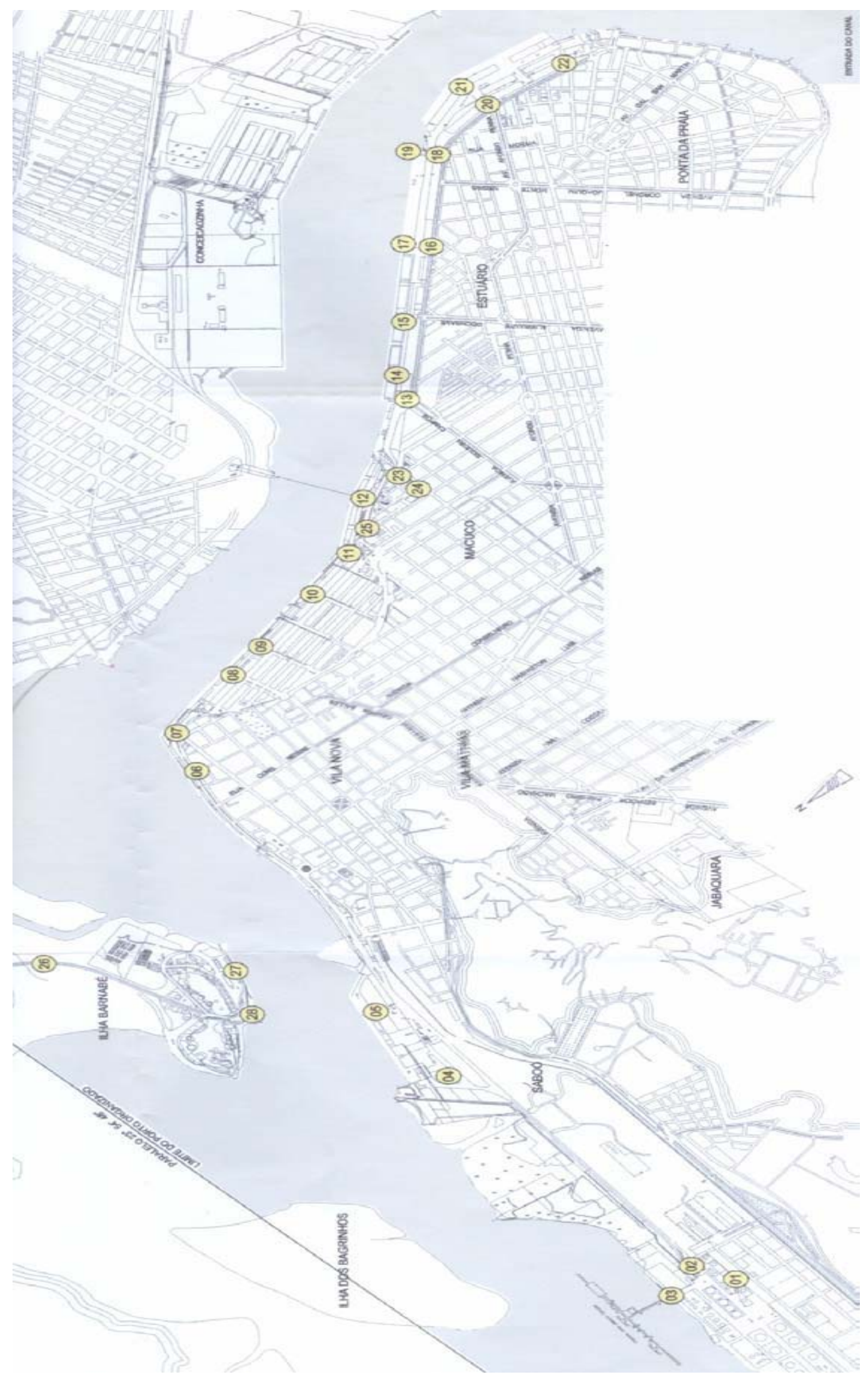




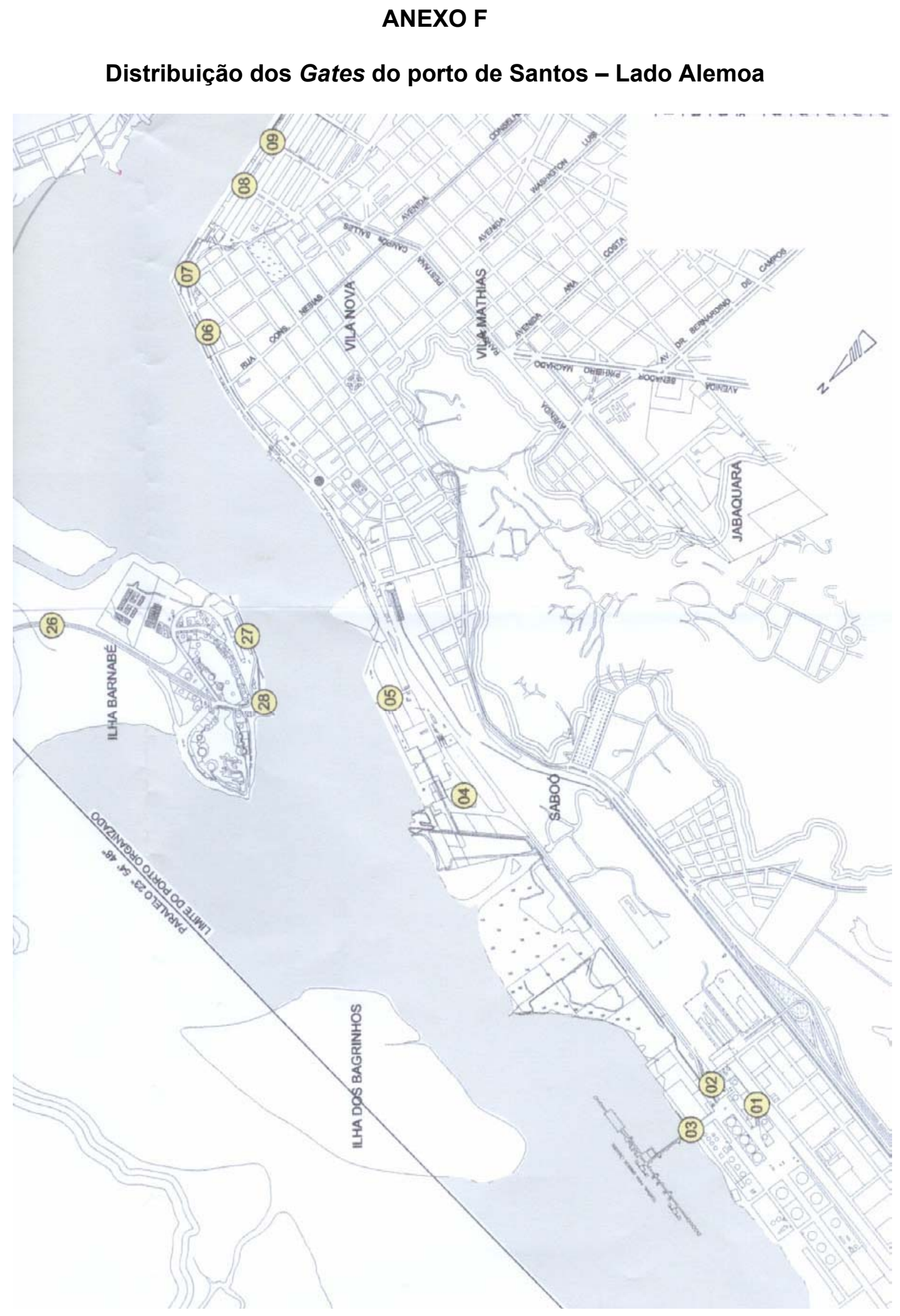




\section{ANEXO G}

Distribuição dos Gates do porto de santos - Lado Ponta da Praia

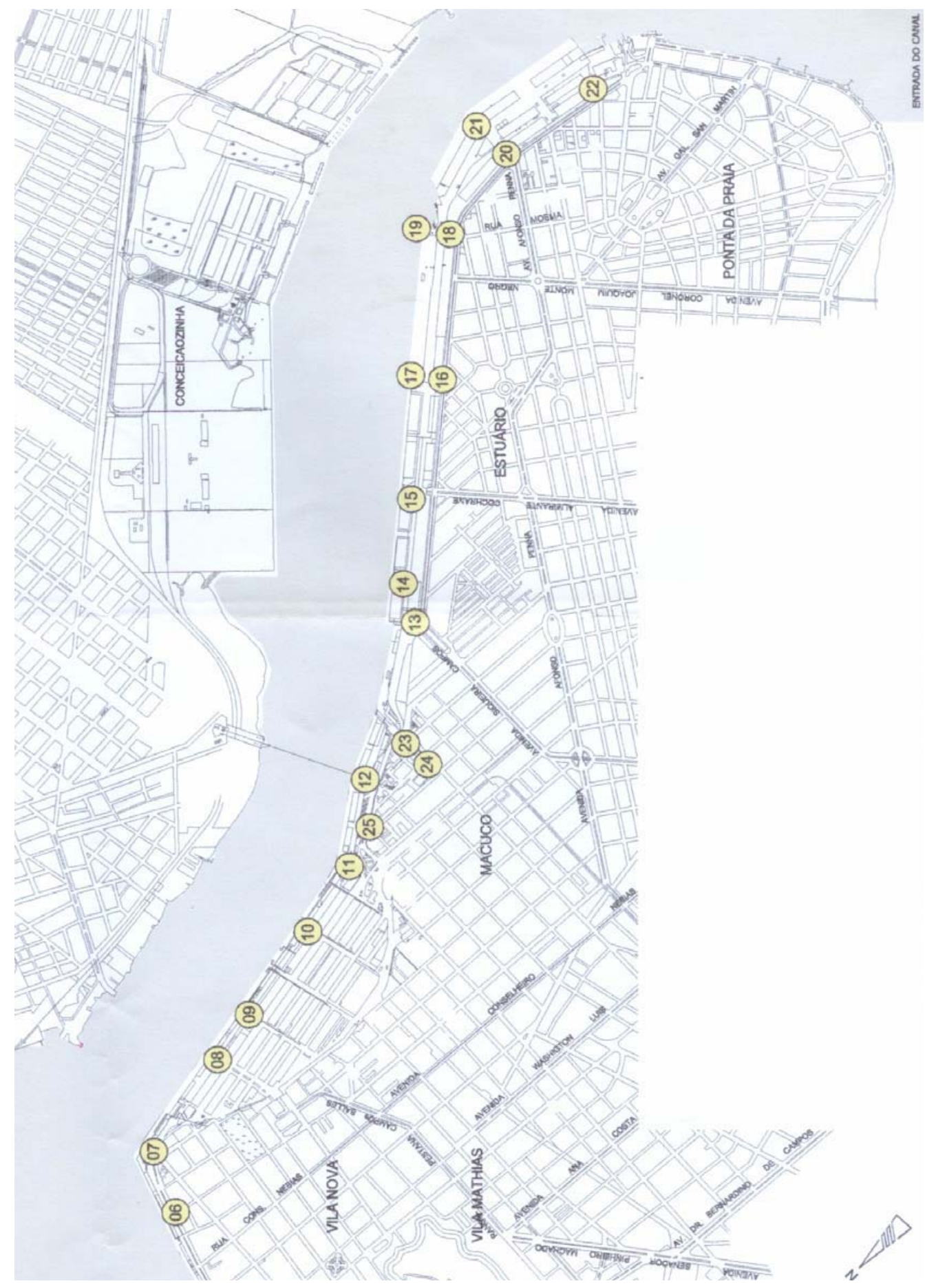




\section{ANEXO H}

\section{Documentos exigidos para Cadastramento de Responsável e Usuários}

\section{Responsável:}

Pessoa Jurídica - com crachá da Alfândega:

- Não há necessidade de apresentar qualquer documento.

\section{Pessoa Jurídica - sem crachá da Alfândega:}

- Cópia do contrato social da empresa; e

- Cópia do cartão do C.N.P.J.

\section{Pessoa Física - com crachá da Alfândega:}

- Apresentar apenas a autorização da Alfândega

\section{Pessoa Física - sem crachá da Alfândega:}

- Ofício de encaminhamento de documentação;

- Ficha de Cadastramento de Responsável (modelo abaixo);

- Cópia do RG, CPF e CTPS comprovando vinculo empregatício ou procuração para terceiros (no caso de sócios da empresa, já está comprovado no contrato social);

- A Pessoa Física deve apresentar procuração específica com poderes para incluir, excluir e atualizar os dados dos funcionários que terão acesso à zona portuária.

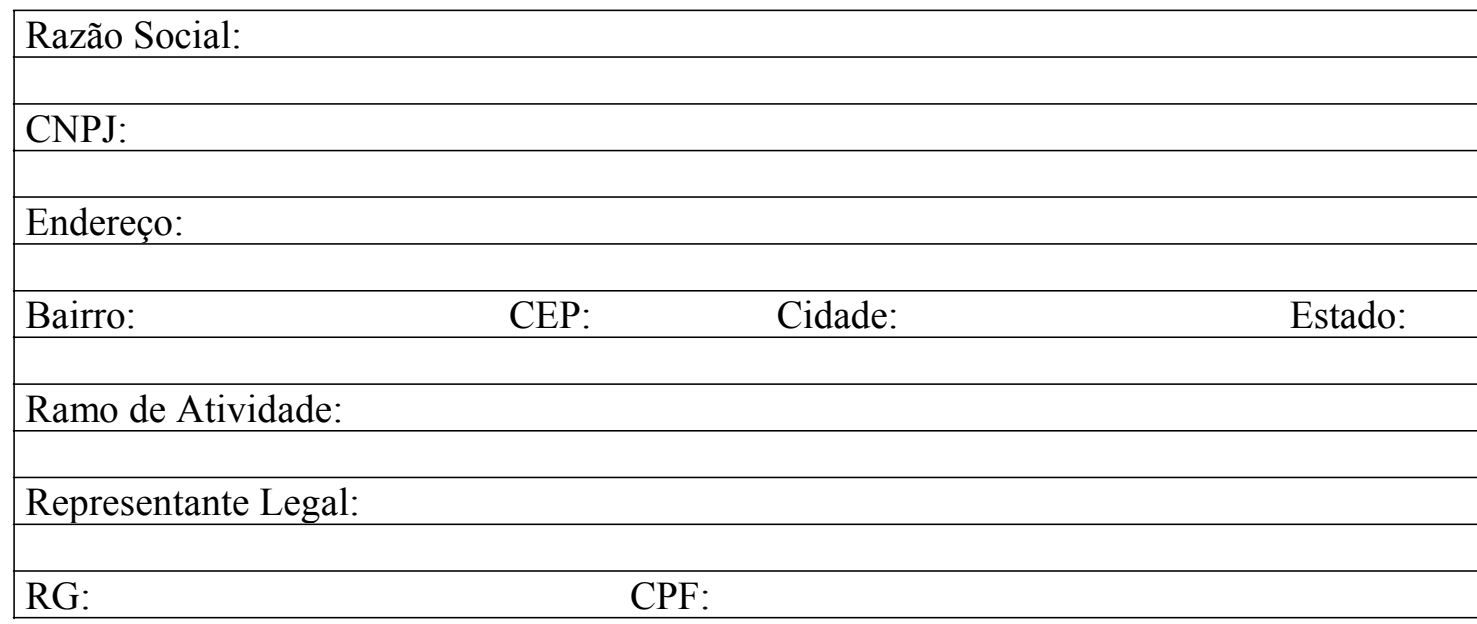

Dados dos autorizados a solicitar credenciamento no site

\begin{tabular}{|l|}
\hline Nome: \\
\hline RG: \\
\hline
\end{tabular}

\begin{tabular}{|l|}
\hline Nome: \\
\hline \\
\hline RG:
\end{tabular}


Declaro que as informações aqui prestadas são a expressão da verdade.

Assinatura do Representante Legal:

Local Data

\begin{tabular}{|l|}
\hline \multicolumn{2}{|l|}{ Responsável pelo Credenciamento (uso CODESP): } \\
\hline RG: \\
\hline
\end{tabular}

Cadastro de Pessoas:

- Cópia RG, CPF, CPTS, CNH;

- Autônomos: cópia do contrato de prestação de serviço;

- Ainda exige-se: CPJ - Certidão do Poder Judiciário para fins criminais, atualizada, expedida na Comarca de Residência do empregado ou prestador de serviços (original ou cópia autenticada em cartório).

Cadastro de Veículos:

- Certificado de Registro e Licenciamento de Veículos devidamente regularizado e, se locado ou arrendado, apresentar contrato de locação ou arrendamento mercantil; e

- Cópia do ANTT do veículo;

\section{Cadastro de Motoristas:}

- Não devem portar crachá da Alfândega; e

- Apresentar cópias da CNH, CPF, RG e Certidão do Poder Judiciário (CPJ).

Pessoas e veículos só poderão ser solicitados após o cadastro efetivado da empresa ou entidade "Responsável".

\section{Usuários que possuem crachás emitidos pela Alfândega}

Os usuários que já possuem crachás emitidos pela Alfândega deverão informar no formulário de solicitação do site esta situação, e não será necessário apresentar a documentação relacionada. O crachá atual será recolhido na entrega da nova credencial. Esta credencial terá a mesma validade do crachá da Alfândega e também será utilizado para os mesmos fins, inclusive acesso as dependências da Alfândega.

Para a renovação a Alfândega publicará Ordem de Serviço específica definindo a documentação necessária. Vale ressaltar que os usuários que estiverem com suas credenciais vencendo, devem procurar a Alfândega para atualização, pois não serão substituídos crachás vencidos. 


\section{ANEXO I \\ Especificações técnicas para distribuição das senhas de leitura dos crachás de acesso}

As empresas e terminais portuários, que desejarem utilizar os crachás emitidos pela CODESP em seu sistema interno de controle de acesso, precisam conhecer as senhas de leitura dos setores de dados dos cartões, conforme descrito no anexo C. A CODESP não fornecerá de forma visual os códigos de senhas. Será fornecido um cartão Mifare contendo os códigos de senhas necessários.

Atenção: Somente as empresas que possuem sistemas de controle de acesso que irão ler eletronicamente o crachá da CODESP é que necessitam deste cartão de senhas.

\section{Procedimento para obtenção das senhas de leitura:}

- A empresa solicita a CODESP o cartão com as senhas de leitura e justificam esta necessidade descrevendo sucintamente o sistema de controle de acesso que possuem;

- CODESP avalia a necessidade da empresa e emite cartão com as senhas;

- CODESP convoca o representante legal da empresa para retirada do cartão de senhas e documento com a senha* deste cartão;

- Representante legal da empresa no ato da retirada, assina termo de compromisso de não divulgação do material fornecido;

(*) O cartão de senhas também possui uma senha de acesso.

De posse do cartão a empresa poderá incluir as senhas de leitura dos crachás CODESP em seu sistema interno de controle de acesso, para isso deve contar com seu fornecedor do sistema. Todas as informações técnicas necessárias estão contidas neste anexo.

Este cartão continuará de posse da empresa indefinidamente, dando autonomia à empresa para realização dos trabalhos de manutenção de seu sistema sempre que necessário. Portanto, nenhum contato técnico com a CODESP será necessário para os eventos de manutenção ou ampliação do sistema interno de controle de acesso da empresa.

O representante legal da empresa deverá manter em sigilo tanto o cartão de senhas como a senha de leitura do mesmo, guardando-os em local seguro e utilizando-os somente nos momentos necessários. No momento da utilização, um representante da empresa deverá acompanhar os trabalhos técnicos para garantir a segurança do processo. 


\section{CARACTERISTICAS TÉCNICAS}

O cartão de senhas também possui uma senha para utilização, e é esta senha que estará grafada no documento entregue pela CODESP ao representante legal da empresa. Se esta senha for perdida, será impossível acessar as informações deste cartão.

\section{Layout interno do cartão de senhas:}

O cartão de senhas contém as senhas de leitura dos setores 1 a 4 do crachá (cartão de acesso) e a senha de gravação do setor 4. Cada senha possui 6 bytes, portanto somente o setor 1 foi utilizado e cada bloco contém 2 bytes de cada senha, conforme layout abaixo:

SETOR 1

\begin{tabular}{|c|c|c|c|c|c|c|c|c|c|c|c|c|c|c|c|c|c|}
\hline \multicolumn{2}{|c|}{ Byte } & $\mathbf{0}$ & $\mathbf{1}$ & $\mathbf{2}$ & $\mathbf{3}$ & $\mathbf{4}$ & $\mathbf{5}$ & $\mathbf{6}$ & $\mathbf{7}$ & $\mathbf{8}$ & $\mathbf{9}$ & $\mathbf{1 0}$ & $\mathbf{1 1}$ & $\mathbf{1 2}$ & $\mathbf{1 3}$ & $\mathbf{1 4}$ & $\mathbf{1 5}$ \\
\hline & $\mathbf{0}$ & L1.1 & L1.2 & FF & FF & L2.1 & L2.2 & FF & FF & L3.1 & L3.2 & FF & FF & L4.1 & L4.2 & G4.1 & G4.2 \\
\hline 1 & L1.3 & L1.4 & FF & FF & L2.3 & L2.4 & FF & FF & L3.3 & L3.4 & FF & FF & L4.3 & L4.4 & G4.3 & G4.4 \\
\hline $\mathbf{2}$ & L1.5 & L1.6 & FF & FF & L2.5 & L2.6 & FF & FF & L3.5 & L3.6 & FF & FF & L4.5 & L4.6 & G4.5 & G4.6 \\
\hline
\end{tabular}

\section{Legenda: Lm.n e Gm.n}

$\mathbf{L}=$ Senha de Leitura

$\mathbf{G}=$ Senha de Gravação

$\mathbf{m}=$ Setor do crachá (1 a 4)

$\mathbf{n}=$ Byte da senha (bytes de 1 a 6 )

$\mathbf{F F}=$ Não usado

Logo, a senha de leitura do setor 1 corresponde aos 6 bytes: L1.1 + L1.2 + L1.3 + L1.4

+ L1.5 + L1.6 e assim sucessivamente. 


\section{ANEXO J \\ Especificações técnicas dos arquivos de dados a serem trocados na Supervia Eletrônica de Dados}

O arquivo-remessa deverá ter a seguinte formatação:

CODIGOSEG NNNNN.TXT

seqüencial

código da Empresa na Supervia

Exemplo: 001SEG00045.TXT

001 - CÓDIGO DA EMPRESA NA SUPERVIA

SEG - FIXO PARA PROJETO DE SEGURANÇA

00045 - SEQÜENCIAL CRESCENTE DE 1 A 1 PARA A EMPRESA

INDEPENDENTE DO TIPO DE ARQUIVO

a) Estrutura dos arquivos-remessa

Formato:

Meios de Comunicação:

Supervia

Internet

Tipos de Registro:

Organização:

Header, Transação e Trailler

Tipo de Campo: eqüencial

Sistema de Codificação:

Zonado

Estrutura do Arquivo:

ASCII

Formato Supervia

Remessa: - Registro (801) - HEADER DO ARQUIVO

Registro (802) - TRANSAÇÃO SOLICITAÇÃO DE EMPRESAS

Registro (803) - TRANSAÇÃO SOLICITAÇÃO DE PESSOAS

TRANSAÇÃO SOLICITAÇÃO DE PESSOAS n

Registro (804) - TRANSAÇÃO SOLICITAÇÃO DE VEÍCULOS

TRANSAÇÃO SOLICITAÇÃO DE VEÍCULOS n

Registro (899) - TRAILLER DO ARQUIVO

b) Meio de comunicação

Serviço disponibilizado pelas VANs, empresas de tecnologia de transmissão segura de dados via Internet.

c) Layout

N - NUMÉRICO $\Rightarrow$ Os campos numéricos deverão ser alinhados à direita e preenchidos com "zeros" à esquerda, quando for o caso.

A - ALFANUMÉRICO (CONTEÚDO EM CAIXA ALTA - LETRAS MAIÚSCULAS) 
REGISTRO HEADER (CABEÇALHO) DO ARQUIVO

\begin{tabular}{|c|l|c|l|c|c|}
\hline $\begin{array}{c}\text { POS. REG. } \\
\text { DE } \quad \text { A }\end{array}$ & \multicolumn{1}{|c|}{ CAMPO/SIGNIFICADO } & $\begin{array}{c}\text { QTDE } \\
\text { DIG. }\end{array}$ & \multicolumn{1}{|c|}{ CONTEÚDO } & A & N \\
\hline 001 A 003 & IDENTIFICAÇÃO DO REGISTRO & 003 & FIXO (801 ) & & $\mathrm{X}$ \\
\hline 004 A 017 & $\begin{array}{l}\text { CNPJ RESPONSÁVEL PELO } \\
\text { ENVIO }\end{array}$ & 014 & NÚMERO DO CNPJ & & $\mathrm{X}$ \\
\hline 018 A 031 & CNPJ RESPONSÁVEL & 014 & NÚMERO DO CNPJ & & $\mathrm{X}$ \\
\hline 032 A 091 & NOME RESPONSÁVEL & 060 & RAZÃO SOCIAL & $\mathrm{X}$ & \\
\hline 092 A 099 & DATA GRAVAÇÃO DO ARQUIVO & 008 & $\begin{array}{l}\text { DDMMAAAA } \\
\text { OBRIGATÓRIO }\end{array}$ & & $\mathrm{X}$ \\
\hline 100 A 105 & HORA GRAVAÇÃO DO ARQUIVO & 006 & $\begin{array}{l}\text { HHMMSS } \\
\text { OBRIGATÓRIO }\end{array}$ & $\mathrm{X}$ \\
\hline 106 A 111 & $\begin{array}{l}\text { NÚMERO SEQUENCIAL DO } \\
\text { REGISTRO }\end{array}$ & 006 & $\begin{array}{l}\text { SEQUENCIAL CRESCENTE } \\
\text { DE 1 A 1 NO ARQUIVO } \\
\text { OBRIGATÓRIO - O HEADER } \\
\text { SERÁ SEMPRE 000001 }\end{array}$ & & $\mathrm{X}$ \\
\hline
\end{tabular}

Identificação do Registro: número identificador do registro header (cabeçalho) do arquivo. Fixo '801'.

CNPJ Responsável pelo Envio: CNPJ do Responsável pelo envio do arquivo.

CNPJ Responsável: CNPJ da entidade caracterizada como Responsável.

Nome Responsável: razão social da entidade caracterizada como Responsável.

Data Gravação do Arquivo: data em que o arquivo foi gerado. Formato DDMMAAAA (dia/mês/ano).

Hora Gravação do Arquivo: hora em que o arquivo foi gerado. Formato: HHMMSS (horas/minutos/segundos).

Número Seqüencial do Registro: número seqüencial associado ao registro. No header, esse campo deverá sempre ser preenchido como '000001'. 
REGISTRO SOLICITAÇĀO DE EMPRESAS

\begin{tabular}{|c|c|c|c|c|c|}
\hline $\begin{array}{c}\text { POS. REG. } \\
\text { DE A }\end{array}$ & CAMPO/SIGNIFICADO & $\begin{array}{l}\text { QTDE } \\
\text { DIG. }\end{array}$ & CONTEÚDO & $\mathbf{A}$ & $\mathbf{N}$ \\
\hline 001 A 003 & IDENTIFICAÇÃO DO REGISTRO & 003 & FIXO (802) & & $\mathrm{X}$ \\
\hline 004 A 017 & CNPJ RESPONSAVEL & 014 & NÚMERO DO CNPJ & & $\mathrm{X}$ \\
\hline 018 A 031 & CNPJ EMPRESA & 014 & NÚMERO DO CNPJ & & $\mathrm{X}$ \\
\hline 032 A 091 & NOME EMPRESA & 060 & RAZÃO SOCIAL & $\mathrm{X}$ & \\
\hline 092 A 111 & CONTRATO & 020 & $\begin{array}{l}\text { CONTRATO DA EMPRESA } \\
\text { COM A CODESP }\end{array}$ & $\mathrm{X}$ & \\
\hline 112 A 161 & RESPONSÁVEL EMPRESA & 050 & $\begin{array}{l}\text { RESPONSÁVEL DA } \\
\text { EMPRESA }\end{array}$ & $\mathrm{X}$ & \\
\hline 162 A 172 & CPF RESPONSAVEL EMPRESA & 011 & $\begin{array}{l}\text { CPF DO RESPONSÁVEL DA } \\
\text { EMPRESA }\end{array}$ & & $\bar{X}$ \\
\hline 173 A 202 & FUNÇÃO & 030 & $\begin{array}{l}\text { FUNÇÃO DO RESPONSAVEL } \\
\text { DA EMPRESA }\end{array}$ & $\mathrm{X}$ & \\
\hline 203 A 217 & INSCRIÇÃO ESTADUAL & 015 & $\begin{array}{l}\text { INSCRIÇÃO ESTADUAL DA } \\
\text { EMPRESA }\end{array}$ & & $\bar{X}$ \\
\hline 218 A 232 & INSCRIÇÃO MUNICIPAL & 015 & $\begin{array}{l}\text { INSCRIÇÃO MUNICIPAL DA } \\
\text { EMPRESA }\end{array}$ & & $\mathrm{X}$ \\
\hline 233 A 282 & ENDEREÇO & 050 & ENDEREÇO DA EMPRESA & $\mathrm{X}$ & \\
\hline 283 A 292 & NÚMERO & 010 & NÚMERO DA EMPRESA & $\mathrm{X}$ & \\
\hline 293 A 312 & COMPLEMENTO & 020 & $\begin{array}{l}\text { COMPLEMENTO DA } \\
\text { EMPRESA }\end{array}$ & $\mathrm{X}$ & \\
\hline 313 A 342 & BAIRRO & 030 & BAIRRO DA EMPRESA & $\mathrm{X}$ & \\
\hline 343 A 372 & CIDADE & 030 & CIDADE DA EMPRESA & $\mathrm{X}$ & \\
\hline 373 A 374 & UF & 002 & $\begin{array}{l}\text { UNIDADE FEDERAL DA } \\
\text { EMPRESA }\end{array}$ & $\mathrm{X}$ & \\
\hline 375 A 383 & CEP & 009 & CEP DA EMPRESA & $\mathrm{X}$ & \\
\hline 384 A 413 & TELEFONE & 030 & TELEFONE DA EMPRESA & $\mathrm{X}$ & \\
\hline 414 A 443 & FAX & 030 & FAX DA EMPRESA & $\mathrm{X}$ & \\
\hline 444 A 493 & EMAIL & 050 & EMAIL DA EMPRESA & $\mathrm{X}$ & \\
\hline 494 A 494 & AGENCIA MARITIMA & 001 & $S-N$ & $\mathrm{X}$ & \\
\hline 495 A 495 & OPERADOR PORTUARIO & 001 & $\mathrm{~S}-\mathrm{N}$ & $\mathrm{X}$ & \\
\hline 496 A 496 & DESPACHANTE & 001 & $S-N$ & $\mathrm{X}$ & \\
\hline 497 A 497 & NVOCC & 001 & $\mathrm{~S}-\mathrm{N}$ & $\mathrm{X}$ & \\
\hline 498 A 498 & ARMADOR & 001 & $\mathrm{~S}-\mathrm{N}$ & $\mathrm{X}$ & \\
\hline 499 A 499 & RECINTO ALFANDEGADO & 001 & $\mathrm{~S}-\mathrm{N}$ & $\mathrm{X}$ & \\
\hline 500 A 500 & IMPORTADOR/EXPORTADOR & 001 & $S-N$ & $\mathrm{X}$ & \\
\hline 501 A 501 & EADI & 001 & $\mathrm{~S}-\mathrm{N}$ & $\mathrm{X}$ & \\
\hline
\end{tabular}




\begin{tabular}{|l|l|c|l|c|c|}
\hline 502 A 502 & REDEX & 001 & S - N & X & \\
\hline 503 A 503 & ARRENDATARIO & 001 & S - N & X & \\
\hline 504 A 504 & PRESTADORES DE SERVIÇOS & 001 & S - N & X & \\
\hline 505 A 505 & OUTROS & 001 & S - N & X & \\
\hline 506 A 511 & $\begin{array}{l}\text { NÚMERO SEQUENCIAL DO } \\
\text { REGISTRO }\end{array}$ & 006 & $\begin{array}{l}\text { OBRIGATÓRIO - VARIÁVEL } \\
\text { NÚMERO SEQUENCIAL }\end{array}$ & X \\
\hline
\end{tabular}

Identificação do Registro: número identificador do registro de solicitação de cadastramento de empresas do arquivo. Fixo '802'.

CNPJ Responsável: CNPJ do Responsável pelo envio do arquivo.

CNPJ Empresa: CNPJ da Empresa cujo cadastramento está sendo solicitado pelo Responsável.

Nome Empresa: razão social da Empresa cujo cadastramento está sendo solicitado pelo Responsável.

Contrato: número do contrato da Empresa com a CODESP.

Responsável Empresa: nome do Responsável pela Empresa.

CPF Responsável Empresa: CPF do Responsável da Empresa.

Função: função do Responsável junto à Empresa.

Inscrição Estadual: identificação da inscrição estadual da Empresa, se houver.

Inscrição Municipal: identificação da inscrição municipal da Empresa, se houver.

Endereço: endereço da Empresa.

Número: número do endereço da Empresa.

Complemento: informações complementares sobre endereço da Empresa.

Bairro: bairro referente ao endereço da Empresa.

UF: sigla de Unidade da Federação referente ao endereço da Empresa.

CEP: CEP referente ao endereço da Empresa.

Telefone: número de telefone da Empresa.

Fax: número do fax da Empresa.

E-mail: endereço eletrônico da Empresa. 
Os campos referentes às posições 494 a 505 identificam o(s) ramo(s) de atividade da Empresa, e devem ser preenchidos com a opção 'S' de SIM, caso a Empresa exerça a atividade indicada ou ' $\mathrm{N}$ ' de $\mathrm{NÃO}$, em caso contrário. Ex: caso determinada Empresa atue como OPERADOR PORTUÁRIO e RECINTO ALFANDEGO, ela deverá preencher as posições 495 e 499 com ' $S$ ' e as outras posições restantes entre 494 e 505 com ' $\mathrm{N}$ '.

Número Seqüencial do Registro: número seqüencial associado ao registro.

\section{REGISTRO SOLICITAÇÃO DE PESSOAS}

\begin{tabular}{|c|c|c|c|c|c|}
\hline $\begin{array}{l}\text { POS. REG. } \\
\text { DE A }\end{array}$ & CAMPO/SIGNIFICADO & $\begin{array}{l}\text { QTDE } \\
\text { DIG. }\end{array}$ & CONTEÚDO & $\mathbf{A}$ & $\mathbf{N}$ \\
\hline 001 A 003 & IDENTIFICAÇÃO DO REGISTRO & 003 & FIXO (803) & & $\mathrm{X}$ \\
\hline 004 A 017 & CNPJ RESPONSAVEL & 014 & NÚMERO DO CNPJ & & $\bar{X}$ \\
\hline 018 A 031 & CNPJ EMPRESA & 014 & NÚMERO DO CNPJ & & $\bar{X}$ \\
\hline 032 A 051 & CONTRATO & 020 & CONTRATO DA EMPRESA & $\mathrm{X}$ & \\
\hline 052 А 056 & TIPO PESSOA & 005 & $\begin{array}{l}\text { CODIGO DO TIPO DE } \\
\text { PESSOA }\end{array}$ & & $\bar{X}$ \\
\hline 057 A 076 & REGISTRO FUNCIONAL & 020 & REGISTRO FUNCIONAL & $\mathrm{X}$ & \\
\hline 077 A 126 & NOME & 050 & NOME DA PESSOA & $\mathrm{X}$ & \\
\hline 127 A 176 & NOME PAI & 050 & NOME DO PAI DA PESSOA & $\mathrm{X}$ & \\
\hline 177 A 226 & NOME MÃE & 050 & NOME DA MÁE DA PESSOA & $\mathrm{X}$ & \\
\hline 227 A 241 & $\mathrm{CNH}$ & 015 & CNH DA PESSOA & $\mathrm{X}$ & \\
\hline 242 А 246 & TIPO DOCUMENTO & 005 & $\begin{array}{l}\text { CODIGO TIPO DE } \\
\text { DOCUMENTO }\end{array}$ & & $\mathrm{X}$ \\
\hline 247 A 261 & DOCUMENTO & 015 & DOCUMENTO DA PESSOA & $\mathrm{X}$ & \\
\hline 262 А 291 & LOCAL DE EMISSÃO & 030 & LOCAL DE EMISSÃO & $\mathrm{X}$ & \\
\hline 292 A 293 & ESTADO DE EMISSÃO & 002 & ESTADO DE EMISSÃO & $\mathrm{X}$ & \\
\hline 294 A 301 & DATA EMISSAO & 008 & $\begin{array}{l}\text { DATA DE EMISSÃO DO RG } \\
\text { (DDMMAAAA) }\end{array}$ & & $\mathrm{X}$ \\
\hline 302 A 306 & NACIONALIDADE & 005 & $\begin{array}{l}\text { CODIGO DA } \\
\text { NACIONALIDADE }\end{array}$ & & $\mathrm{X}$ \\
\hline 307 A 317 & $\mathrm{CPF}$ & 011 & CPF DA PESSOA & & $\mathrm{X}$ \\
\hline 318 А 337 & POSTO & 020 & $\begin{array}{l}\text { POSTO DE COMANDO } \\
\text { (SOMENTE PARA TIPO } \\
\text { PESSOA TRIPULANTES) }\end{array}$ & $\mathrm{X}$ & \\
\hline
\end{tabular}




\begin{tabular}{|c|c|c|c|c|c|}
\hline 338 A 367 & FUNCAO & 030 & FUNÇÃO & $\mathrm{X}$ & \\
\hline 368 A 375 & DATA NASCIMENTO & 008 & $\begin{array}{l}\text { DATA DE NASCIMENTO DA } \\
\text { PESSOA (DDMMAAAA) }\end{array}$ & & $\bar{X}$ \\
\hline 376 A 405 & CIDADE & 030 & $\begin{array}{l}\text { CIDADE DE NASCIMENTO } \\
\text { DA PESSOA }\end{array}$ & $\mathrm{X}$ & \\
\hline 406 A 407 & UF & 002 & \begin{tabular}{|l} 
UNIDADE FEDERAL DE \\
NASCIMENTO DA PESSOA
\end{tabular} & $\mathrm{X}$ & \\
\hline 408 A 411 & TIPO SANGUE & 004 & $\begin{array}{l}\text { TIPO SANGUINEO DA } \\
\text { PESSOA }\end{array}$ & $\mathrm{X}$ & \\
\hline 412 A 461 & ENDEREÇO & 050 & ENDEREÇO DA PESSOA & $\mathrm{X}$ & \\
\hline 462 A 471 & NÚMERO & 010 & NÚMERO DA PESSOA & $\bar{X}$ & \\
\hline 472 A 491 & COMPLEMENTO & 020 & COMPLEMENTO DA PESSOA & $\mathrm{X}$ & \\
\hline 492 A 521 & BAIRRO & 030 & BAIRRO DA PESSOA & $\mathrm{X}$ & \\
\hline 522 A 551 & CIDADE & 030 & CIDADE DA PESSOA & $\mathrm{X}$ & \\
\hline 552 A 553 & UF & 002 & $\begin{array}{l}\text { UNIDADE FEDERAL DA } \\
\text { RESIDÊNCIA DA PESSOA }\end{array}$ & $\mathrm{X}$ & \\
\hline 554 A 562 & CEP & 009 & CEP DA PESSOA & $\mathrm{X}$ & \\
\hline 563 А 592 & TELEFONE 1 & 030 & TELEFONE DA PESSOA & $\mathrm{X}$ & \\
\hline 593 А 622 & TELEFONE 2 & 030 & TELEFONE DA PESSOA & $\mathrm{X}$ & \\
\hline 623 A 672 & EMAIL & 050 & EMAIL DA PESSOA & $\mathrm{X}$ & \\
\hline 673 A 822 & GATES DE ACESSO & 150 & GATES DE ACESSO AO CAIS & & $\bar{X}$ \\
\hline 823 A 830 & DATA INICIAL DE ACESSO & 008 & $\begin{array}{l}\text { DATA DE INICIAL DE } \\
\text { ACESSO (DDMMAAAA) } \\
\end{array}$ & & $\mathrm{X}$ \\
\hline 831 A 838 & DATA FINAL & 008 & $\begin{array}{l}\text { DATA FINAL DE ACESSO } \\
\text { (DDMMAAAA) }\end{array}$ & & $\bar{X}$ \\
\hline 839 A 839 & ACESSO AO NAVIO & 001 & $(\mathrm{~S}-\mathrm{SIM}, \mathrm{N}-\mathrm{NÃO})$ & $\bar{X}$ & \\
\hline 840 A 840 & SITUAÇÃO & 001 & $\begin{array}{l}(1-\text { SOLICITAÇÃO, } 2- \\
\text { CANCELAMENTO })\end{array}$ & $\bar{X}$ & \\
\hline 841 A 846 & $\begin{array}{l}\text { NÚMERO SEQUENCIAL DO } \\
\text { REGISTRO }\end{array}$ & 006 & $\begin{array}{l}\text { OBRIGATÓRIO - VARIÁVEL } \\
\text { NÚMERO SEQUENCIAL }\end{array}$ & & $\mathrm{X}$ \\
\hline
\end{tabular}

Identificação do Registro: número identificador do registro de solicitação de cadastramento de pessoas do arquivo. Fixo '803'.

CNPJ Responsável: CNPJ do Responsável pelo envio do arquivo.

CNPJ Empresa: CNPJ da Empresa cujo cadastramento de pessoa está sendo solicitado pelo Responsável.

Contrato: número do contrato da Empresa com a CODESP.

Tipo Pessoa: código do tipo de pessoa, conforme opções a seguir: 


\begin{tabular}{|c|l|}
\hline Código & \multicolumn{1}{|c|}{ Tipo } \\
\hline $\mathbf{0 0 0 0 1}$ & Visitantes \\
\hline $\mathbf{0 0 0 0 2}$ & Prestadores Serviços CODESP \\
\hline $\mathbf{0 0 0 0 3}$ & Prestadores de Serviços do Porto \\
\hline $\mathbf{0 0 0 0 4}$ & Prestadores de Serviços da Alfândega \\
\hline $\mathbf{0 0 0 0 5}$ & Funcionários CODESP \\
\hline $\mathbf{0 0 0 0 6}$ & Funcionário OGMO \\
\hline $\mathbf{0 0 0 0 7}$ & Tripulantes \\
\hline $\mathbf{0 0 0 0 8}$ & Transportador eventual \\
\hline $\mathbf{0 0 0 0 9}$ & Funcionário Praticagem \\
\hline $\mathbf{0 0 0 1 0}$ & Funcionários Alfândega \\
\hline $\mathbf{0 0 0 1 1}$ & Diretoria CODESP \\
\hline $\mathbf{0 0 0 1 2}$ & Imprensa \\
\hline $\mathbf{0 0 0 1 3}$ & Funcionário de Sindicatos \\
\hline $\mathbf{0 0 0 1 4}$ & Funcionários de demais Autoridades \\
\hline $\mathbf{0 0 0 1 5}$ & Motoristas \\
\hline $\mathbf{0 0 0 1 6}$ & Trabalhadores Portuários Avulsos (TPA) \\
\hline
\end{tabular}

Registro Funcional: número funcional da pessoa na Empresa.

Nome: nome completo da pessoa.

Nome Pai: nome completo do pai da pessoa.

Nome Mãe: nome completo da mãe da pessoa.

CNH: número do registro de habilitação da pessoa, se houver.

Tipo Documento: tipo do documento de identificação da pessoa, conforme opções a seguir:

\begin{tabular}{|c|l|}
\hline Código & \multicolumn{1}{c|}{ Tipo } \\
\hline $\mathbf{0 0 0 0 1}$ & RG \\
\hline $\mathbf{0 0 0 0 2}$ & Passaporte \\
\hline $\mathbf{0 0 0 0 3}$ & RNE \\
\hline
\end{tabular}

Documento: número de identificação do documento da pessoa.

Local de Emissão: local de emissão do documento da pessoa.

Estado de Emissão: estado de emissão do documento da pessoa, conforme siglas de Unidades da Federação.

Data Emissão: data de emissão do documento da pessoa. Formato DDMMAAAA (dia/mês/ano). 
Nacionalidade: nacionalidade da pessoa, conforme tabela de códigos da RAIS.

CPF: CPF da pessoa.

Posto: posto de comando da pessoa, em caso de TIPO PESSOA = '00007’ (tripulante).

Função: função da pessoa.

Data Nascimento: data de nascimento da pessoa. Formato: Formato DDMMAAAA (dia/mês/ano).

Cidade: cidade de nascimento da pessoa.

UF: sigla da Unidade da Federação de nascimento da pessoa.

Tipo Sangue: tipo sanguíneo da pessoa, conforme opções a seguir: 'A+', 'A-‘, 'AB+', 'AB-', 'O+' ou 'O-'.

Endereço: endereço da pessoa.

Número: número do endereço da pessoa.

Complemento: informações complementares sobre endereço da pessoa.

Bairro: bairro referente ao endereço da pessoa.

UF: sigla de Unidade da Federação referente ao endereço da pessoa.

CEP: CEP referente ao endereço da pessoa.

Telefone 1: número de telefone da pessoa.

Telefone 2: número de telefone adicional da pessoa.

E-mail: endereço eletrônico da pessoa.

Gates de Acesso: códigos dos Gates de acesso previstos para a pessoa. No caso de a solicitação envolver mais de um Gate, os códigos devem ser incluídos em seqüência. Ex: acesso aos Gates 01, 04 e 20, o campo deve ser preenchido como '010420'. Os códigos de Gates são: 


\begin{tabular}{|c|l|}
\hline Código & \multicolumn{1}{|c|}{ Tipo } \\
\hline $\mathbf{0 1}$ & Acesso à Administração da Petrobrás - Alemoa \\
\hline $\mathbf{0 2}$ & Acesso á Alemoa \\
\hline $\mathbf{0 3}$ & Acesso aos Píres da Alemoa \\
\hline $\mathbf{0 4}$ & Acesso à Deicmar e Píer do Saboó \\
\hline $\mathbf{0 5}$ & Rodrimar \\
\hline $\mathbf{0 6}$ & Píer dos armazéns 10/11 \\
\hline $\mathbf{0 7}$ & Píer na DIROP \\
\hline $\mathbf{0 8}$ & VCP \\
\hline $\mathbf{0 9}$ & Teaçu \\
\hline $\mathbf{1 0}$ & Copersucar \\
\hline $\mathbf{1 1}$ & Concais \\
\hline $\mathbf{1 2}$ & T-Grão \\
\hline $\mathbf{1 3}$ & Canal 4 \\
\hline $\mathbf{1 4}$ & Citrosuco/NST - Píer \\
\hline $\mathbf{1 5}$ & CBA TEAG - Píer \\
\hline $\mathbf{1 6}$ & Libra 35 \\
\hline $\mathbf{1 7}$ & TEAG - Píer \\
\hline $\mathbf{1 8}$ & Libra 37 \\
\hline $\mathbf{1 9}$ & Macuco \\
\hline $\mathbf{2 0}$ & Corredor de Exportação \\
\hline $\mathbf{2 1}$ & Acesso ao cais da Libra 37 \\
\hline $\mathbf{2 2}$ & ADM \\
\hline $\mathbf{2 3}$ & Acesso á Presidência \\
\hline $\mathbf{2 4}$ & Saída da Presidência \\
\hline $\mathbf{2 5}$ & Entrada/Saída das ofícinas - área da Presidência \\
\hline $\mathbf{2 6}$ & Acesso por terra à Ilha Barnabé \\
\hline $\mathbf{2 7}$ & Acesso aos Píeres da Illha Barnabé \\
\hline $\mathbf{2 8}$ & Acesso por mar à Ilha Barnabé. \\
\hline & \\
\hline
\end{tabular}

Data Inicial de Acesso: data inicial de acesso para a pessoa. Formato: Formato DDMMAAAA (dia/mês/ano).

Data Final de Acesso: data final de acesso para a pessoa. Formato: Formato DDMMAAAA (dia/mês/ano).

Acesso ao navio: indicação se a pessoa subirá a bordo do navio ou não.

Situação: código da situação do registro referente à pessoa, conforme opções a seguir:

\begin{tabular}{|c|l|}
\hline Código & \multicolumn{1}{c|}{ Tipo } \\
\hline $\mathbf{1}$ & Solicitação \\
\hline $\mathbf{2}$ & Cancelamento \\
\hline
\end{tabular}

Número Seqüencial do Registro: número seqüencial associado ao registro. 
REGISTRO SOLICITAÇĀO DE VEÍCULOS

\begin{tabular}{|c|c|c|c|c|c|}
\hline $\begin{array}{l}\text { POS. REG. } \\
\text { DE A }\end{array}$ & CAMPO/SIGNIFICADO & $\begin{array}{l}\text { QTDE } \\
\text { DIG. }\end{array}$ & CONTEÚDO & $\mathbf{A}$ & $\mathbf{N}$ \\
\hline 001 A 003 & IDENTIFICAÇÃO DO REGISTRO & 003 & FIXO (804) & & $\mathrm{X}$ \\
\hline 004 А 017 & CNPJ RESPONSAVEL & 014 & NÚMERO DO CNPJ & & $\bar{X}$ \\
\hline 018 A 031 & CNPJ EMPRESA & 014 & NÚMERO DO CNPJ & & $\bar{X}$ \\
\hline 032 A 051 & MARCA & 020 & MARCA DO VEİCULO & $\mathrm{X}$ & \\
\hline 052 A 061 & CODIGO RENAVAN & 010 & CODIGO RENAVAN & & $\mathrm{X}$ \\
\hline 062 A 081 & CODIGO EMPRESA & 020 & $\begin{array}{l}\text { CODIGO DO VEICULO NA } \\
\text { EMPRESA }\end{array}$ & $\mathrm{X}$ & \\
\hline 082 A 101 & MODELO & 020 & MODELO DO VEİCULO & $\mathrm{X}$ & \\
\hline 102 A 105 & ANO FABRICAÇÃO & 004 & $\begin{array}{l}\text { ANO DE FABRICAÇÃO DO } \\
\text { VEÍCULO } \\
\end{array}$ & & $\bar{X}$ \\
\hline 106 A 113 & PLACA & 008 & PLACA DO VEÍCULO & $\mathrm{X}$ & \\
\hline 114 A 133 & CHASSI & 020 & CHASSI DO VEICULO & $\mathrm{X}$ & \\
\hline 134 A 138 & TIPO & 005 & $\begin{array}{l}\text { CODIGO DO TIPO DE } \\
\text { VEICULO }\end{array}$ & & $\mathrm{X}$ \\
\hline 139 A 158 & COR & 020 & COR DO VEÍCULO & $\mathrm{X}$ & \\
\hline 159 A 208 & PROPRIETÁRIO & 050 & PROPRIETÁRIO DO VEÍCULO & $\mathrm{X}$ & \\
\hline 209 A 222 & CPF/CNPJ DO PROPRIETARIO & 014 & CPF/CNPJ DO PROPRIETARIO & & $\bar{X}$ \\
\hline 223 A 372 & GATES DE ACESSO & 150 & GATES DE ACESSO AO CAIS & & $\mathrm{X}$ \\
\hline 373 A 386 & ANTT & 015 & CÓDIGO DA ANTT & $\mathrm{X}$ & \\
\hline 387 A 394 & DATA INICIAL DE ACESSO & 008 & $\begin{array}{l}\text { DATA DE INICIAL DE } \\
\text { ACESSO (DDMMYYYY) }\end{array}$ & & $\bar{X}$ \\
\hline 395 A 402 & DATA FINAL & 008 & $\begin{array}{l}\text { DATA FINAL DE ACESSO } \\
\text { (DDMMYYYY) }\end{array}$ & & $\mathrm{X}$ \\
\hline 403 A 403 & SITUAÇÃO & 001 & $\begin{array}{l}1 \text { - SOLICITAÇÃO, } 2 \text { - } \\
\text { CANCELAMENTO }\end{array}$ & & $\mathrm{X}$ \\
\hline 404 A 404 & ACESSO AO NAVIO & 001 & $(\mathrm{~S}-\mathrm{SIM}, \mathrm{N}-\mathrm{N} \tilde{A} O)$ & $\mathrm{X}$ & \\
\hline 405 A 409 & $\begin{array}{l}\text { NÚMERO SEQUENCIAL DO } \\
\text { REGISTRO }\end{array}$ & 006 & $\begin{array}{l}\text { OBRIGATÓRIO - VARIÁVEL } \\
\text { NÚMERO SEQUENCIAL }\end{array}$ & & $\mathrm{X}$ \\
\hline
\end{tabular}


Identificação do Registro: número identificador do registro de solicitação de cadastramento de veículos do arquivo. Fixo '804'.

CNPJ Responsável: CNPJ do Responsável pelo envio do arquivo.

CNPJ Empresa: CNPJ da Empresa cujo cadastramento de veículo está sendo solicitado pelo Responsável.

Marca: marca do veículo.

Código RENAVAM: código RENAVAM do veículo.

Código Empresa: código do veículo na Empresa.

Modelo: modelo do veículo.

Ano Fabricação: ano de fabricação do veículo. Formato: AAAA (ano).

Placa: placa do veículo.

Chassi: identificação do chassi do veículo.

Tipo: código do tipo de veículo, conforme opções a seguir:

\begin{tabular}{|c|l|}
\hline Código & \multicolumn{1}{|c|}{ Tipo } \\
\hline $\mathbf{0 0 0 0 1}$ & Automóvel \\
\hline $\mathbf{0 0 0 0 2}$ & Caminhão \\
\hline $\mathbf{0 0 0 0 3}$ & Peruas \\
\hline $\mathbf{0 0 0 0 4}$ & Caminhonetes \\
\hline $\mathbf{0 0 0 0 5}$ & Van \\
\hline $\mathbf{0 0 0 0 6}$ & Pick-ups \\
\hline $\mathbf{0 0 0 0 7}$ & Microônibus \\
\hline $\mathbf{0 0 0 0 8}$ & Motocicleta \\
\hline $\mathbf{0 0 0 0 9}$ & Furgões \\
\hline $\mathbf{0 0 0 1 0}$ & Ônibus \\
\hline $\mathbf{0 0 0 1 1}$ & Cavalos mecânicos \\
\hline $\mathbf{0 0 0 1 2}$ & Reboque \\
\hline $\mathbf{0 0 0 1 3}$ & Semi-reboque \\
\hline $\mathbf{0 0 0 1 4}$ & Trator \\
\hline $\mathbf{0 0 0 1 5}$ & Trailers \\
\hline $\mathbf{0 0 0 1 6}$ & Outros Veículos \\
\hline $\mathbf{0 0 0 1 7}$ & Equipamentos \\
\hline
\end{tabular}


Cor: cor predominante do veículo.

Proprietário: nome do proprietário do veículo.

CPF/CNPJ do Proprietário: CPF/CNPJ do proprietário do veículo.

Código ANTT: código ANTT do veículo.

Gates de Acesso: códigos dos Gates de acesso previstos para a pessoa. No caso de a solicitação envolver mais de um Gate, os códigos devem ser incluídos em seqüência. Ex: acesso aos Gates 01, 04 e 20, o campo deve ser preenchido como '010420'. Os códigos de Gates são:

\begin{tabular}{|c|l|}
\hline Código & \\
\hline $\mathbf{0 1}$ & Acesso à Administração da Petrobrás - Alemoa \\
\hline $\mathbf{0 2}$ & Acesso á Alemoa \\
\hline $\mathbf{0 3}$ & Acesso aos Píeres da Alemoa \\
\hline $\mathbf{0 4}$ & Acesso à Deicmar e Píer do Saboó \\
\hline $\mathbf{0 5}$ & Rodrimar \\
\hline $\mathbf{0 6}$ & Píer dos armazéns 10/11 \\
\hline $\mathbf{0 7}$ & Píer na DIROP \\
\hline $\mathbf{0 8}$ & VCP \\
\hline $\mathbf{0 9}$ & Teaçu \\
\hline $\mathbf{1 0}$ & Copersucar \\
\hline $\mathbf{1 1}$ & Concais \\
\hline $\mathbf{1 2}$ & T-Grão \\
\hline $\mathbf{1 3}$ & Canal 4 \\
\hline $\mathbf{1 4}$ & Citrosuco/NST - Píer \\
\hline $\mathbf{1 5}$ & CBA TEAG - Píer \\
\hline $\mathbf{1 6}$ & Libra 35 \\
\hline $\mathbf{1 7}$ & TEAG - Píer \\
\hline $\mathbf{1 8}$ & Libra 37 \\
\hline $\mathbf{1 9}$ & Macuco \\
\hline $\mathbf{2 0}$ & Corredor de Exportação \\
\hline $\mathbf{2 1}$ & Acesso ao cais da Libra 37 \\
\hline $\mathbf{2 2}$ & ADM \\
\hline $\mathbf{2 3}$ & Acesso á Presidência \\
\hline $\mathbf{2 4}$ & Saída da Presidência \\
\hline $\mathbf{2 5}$ & Entrada/Saída das oficinas - área da Presidência \\
\hline $\mathbf{2 6}$ & Acesso por terra à Ilha Barnabé \\
\hline $\mathbf{2 7}$ & Acesso aos Píeres da Ilha Barnabé \\
\hline $\mathbf{2 8}$ & Acesso por mar à Ilha Barnabé. \\
\hline & \\
\hline
\end{tabular}

Data Inicial de Acesso: data inicial de acesso para a pessoa. Formato: Formato DDMMAAAA (dia/mês/ano). 
Data Final de Acesso: data final de acesso para a pessoa. Formato: Formato DDMMAAAA (dia/mês/ano).

Situação: código da situação do registro referente à pessoa, conforme opções a seguir:

\begin{tabular}{|c|l|}
\hline Código & \multicolumn{1}{|c|}{ Tipo } \\
\hline $\mathbf{1}$ & Solicitação \\
\hline $\mathbf{2}$ & Cancelamento \\
\hline
\end{tabular}

Número Seqüencial do Registro: número seqüencial associado ao registro.

\section{REGISTRO ACESSO DE PESSOAS}

\begin{tabular}{|c|l|c|l|c|c|}
\hline $\begin{array}{c}\text { POS. REG. } \\
\text { DE A }\end{array}$ & \multicolumn{1}{|c|}{ CAMPO/SIGNIFICADO } & $\begin{array}{c}\text { QTDE } \\
\text { DIG. }\end{array}$ & \multicolumn{1}{|c|}{ CONTEÚDO } & A & N \\
\hline 001 A 003 & IDENTIFICAÇÃO DO REGISTRO & 003 & FIXO (805 ) & & $\mathrm{X}$ \\
\hline 004 A 017 & CNPJ RESPONSAVEL & 014 & NÜMERO DO CNPJ & $\mathrm{X}$ \\
\hline 018 A 022 & TIPO DOCUMENTO & 005 & $\begin{array}{l}\text { CODIGO TIPO DE } \\
\text { DOCUMENTO }\end{array}$ & & $\mathrm{X}$ \\
\hline 023 A 037 & DOCUMENTO & 015 & DOCUMENTO DA PESSOA & $\mathrm{X}$ & \\
\hline 038 A 067 & LOCAL DE EMISSÃO & 030 & LOCAL DE EMISSÃO & $\mathrm{X}$ & \\
\hline 068 A 069 & ESTADO DE EMISSÃO & 002 & ESTADO DE EMISSÃO & $\mathrm{X}$ & \\
\hline 070 A 077 & DATA EMISSAO & 008 & $\begin{array}{l}\text { DATA DE EMISSÃO DO } \\
\text { RG(DDMMYYYY) }\end{array}$ & & $\mathrm{X}$ \\
\hline 078 A 087 & CREDENCIAL DA PESSOA & 010 & CREDENCIAL DA PESSOA & & $\mathrm{X}$ \\
\hline 088 A 092 & CATRACA & 005 & CODIGO DA CATRACA & & $\mathrm{X}$ \\
\hline 093 A 100 & DATA & 008 & $\begin{array}{l}\text { DATA DA ENTRADA OU } \\
\text { SAÍDA (DDMMYYYY) }\end{array}$ & $\mathrm{X}$ \\
\hline 101 A 106 & HORA & 006 & $\begin{array}{l}\text { HORA DA ENTRADA OU } \\
\text { SAÍDA (HHMMSS) }\end{array}$ & $\mathrm{X}$ \\
\hline 107 A 107 & TIPO MOVIMENTO & 001 & 1-ENTRADA / 2-SAIDA & & $\mathrm{X}$ \\
\hline 108 A 113 & $\begin{array}{l}\text { NÚMERO SEQUENCIAL DO } \\
\text { REGISTRO }\end{array}$ & 006 & $\begin{array}{l}\text { OBRIGATÓRIO - VARIÁVEL } \\
\text { NÚMERO SEQUENCIAL }\end{array}$ & $\mathrm{X}$ \\
\hline
\end{tabular}

Identificação do registro: número identificador do registro de acesso de pessoas do arquivo. Fixo '805'.

CNPJ Responsável: CNPJ do Responsável pelo envio do arquivo. 
Tipo Documento: tipo do documento de identificação da pessoa, conforme opções a seguir:

\begin{tabular}{|c|l|}
\hline Código & \multicolumn{1}{|c|}{ Tipo } \\
\hline $\mathbf{0 0 0 0 1}$ & RG \\
\hline $\mathbf{0 0 0 0 2}$ & Passaporte \\
\hline $\mathbf{0 0 0 0 3}$ & RNE \\
\hline
\end{tabular}

Documento: número de identificação do documento da pessoa.

Local de Emissão: local de emissão do documento da pessoa.

Estado de Emissão: estado de emissão do documento da pessoa, conforme siglas de Unidades da Federação.

Data Emissão: data de emissão do documento da pessoa. Formato DDMMAAAA (dia/mês/ano).

Credencial da Pessoa: identificação da credencial da pessoa emitida pela CODESP.

Catraca: código de identificação da catraca pela qual ocorreu o acesso da pessoa.

Data: data do acesso (entrada ou saída) da pessoa. Formato DDMMAAAA (dia/mês/ano).

Hora: hora do acesso (entrada ou saída) da pessoa. Formato DDMMAAAA (dia/mês/ano).

Tipo Movimento: movimento de acesso da pessoa, conforme opções a seguir:

\begin{tabular}{|c|l|}
\hline Código & \multicolumn{1}{c|}{ Tipo } \\
\hline $\mathbf{1}$ & Entrada \\
\hline $\mathbf{2}$ & Saída \\
\hline
\end{tabular}

Número Seqüencial do Registro: número seqüencial associado ao registro.

\section{REGISTRO ACESSO DE VEICULOS}

\begin{tabular}{|c|l|c|l|c|c|}
\hline $\begin{array}{c}\text { POS. REG. } \\
\text { DE A }\end{array}$ & \multicolumn{1}{|c|}{ CAMPO/SIGNIFICADO } & $\begin{array}{c}\text { QTDE } \\
\text { DIG. }\end{array}$ & \multicolumn{1}{|c|}{ CONTEÚDO } & A & N \\
\hline 001 A 003 & IDENTIFICAÇÃO DO REGISTRO & 003 & FIXO (806 ) & & X \\
\hline 004 A 017 & CNPJ RESPONSAVEL & 014 & NÚMERO DO CNPJ & & X \\
\hline 018 A 025 & PLACA & 008 & PLACA DO VEICULO & X & \\
\hline
\end{tabular}




\begin{tabular}{|c|c|c|c|c|c|}
\hline 026 A 045 & CODIGO EMPRESA & 020 & $\begin{array}{l}\text { CODIGO DO VEICULO NA } \\
\text { EMPRESA }\end{array}$ & $\mathrm{X}$ & \\
\hline 046 A 050 & TIPO & 005 & $\begin{array}{l}\text { CODIGO DO TIPO DE } \\
\text { VEICULO }\end{array}$ & & $\mathrm{X}$ \\
\hline 051 A 060 & CREDENCIAL VEÍCULO & 010 & CREDENCIAL DO VEÍCULO & & $\mathrm{X}$ \\
\hline 061 A 065 & CATRACA & 005 & CÓDIGO DA CATRACA & & $\mathrm{X}$ \\
\hline 066 A 073 & DATA & 008 & $\begin{array}{l}\text { DATA DA ENTRADA OU } \\
\text { SAÍDA (DDMMYYYY) }\end{array}$ & & $\mathrm{X}$ \\
\hline 074 A 079 & HORA & 006 & $\begin{array}{l}\text { HORA DA ENTRADA OU } \\
\text { SAÍDA (HHMMSS) }\end{array}$ & & $\mathrm{X}$ \\
\hline 080 A 080 & TIPO MOVIMENTO & 001 & 1-ENTRADA / 2-SAIDA & & $\bar{X}$ \\
\hline 080 A 086 & $\begin{array}{l}\text { NÚMERO SEQUENCIAL DO } \\
\text { REGISTRO }\end{array}$ & 006 & $\begin{array}{l}\text { OBRIGATÓRIO - VARIÁVEL } \\
\text { NÚMERO SEQUENCIAL }\end{array}$ & & $\mathrm{X}$ \\
\hline
\end{tabular}

Identificação do registro: número identificador do registro de acesso de veículos do arquivo. Fixo '806'.

CNPJ Responsável: CNPJ do Responsável pelo envio do arquivo.

Placa: placa do veículo.

Código Empresa: código do veículo na Empresa.

Tipo: código do tipo de veículo, conforme opções a seguir:

\begin{tabular}{|c|l|}
\hline Código & \multicolumn{1}{|c|}{ Tipo } \\
\hline $\mathbf{0 0 0 0 1}$ & Automóvel \\
\hline $\mathbf{0 0 0 0 2}$ & Caminhão \\
\hline $\mathbf{0 0 0 0 3}$ & Peruas \\
\hline $\mathbf{0 0 0 0 4}$ & Caminhonetes \\
\hline $\mathbf{0 0 0 0 5}$ & Van \\
\hline $\mathbf{0 0 0 0 6}$ & Pick-ups \\
\hline $\mathbf{0 0 0 0 7}$ & Microônibus \\
\hline $\mathbf{0 0 0 0 8}$ & Motocicleta \\
\hline $\mathbf{0 0 0 0 9}$ & Furgões \\
\hline $\mathbf{0 0 0 1 0}$ & Ônibus \\
\hline $\mathbf{0 0 0 1 1}$ & Cavalos mecânicos \\
\hline $\mathbf{0 0 0 1 2}$ & Reboque \\
\hline $\mathbf{0 0 0 1 3}$ & Semi-reboque \\
\hline $\mathbf{0 0 0 1 4}$ & Trator \\
\hline $\mathbf{0 0 0 1 5}$ & Trailers \\
\hline $\mathbf{0 0 0 1 6}$ & Outros Veículos \\
\hline $\mathbf{0 0 0 1 7}$ & Equipamentos \\
\hline
\end{tabular}


Credencial Veículo: identificação da credencial do veículo emitida pela CODESP.

Catraca: código de identificação da catraca pela qual ocorreu o acesso do veículo.

Data: data do acesso (entrada ou saída) do veículo. Formato DDMMAAAA (dia/mês/ano).

Hora: hora do acesso (entrada ou saída) do veículo. Formato DDMMAAAA (dia/mês/ano).

Tipo Movimento: movimento de acesso da pessoa, conforme opções a seguir:

\begin{tabular}{|c|l|}
\hline Código & \multicolumn{1}{c|}{ Tipo } \\
\hline $\mathbf{1}$ & Entrada \\
\hline $\mathbf{2}$ & Saída \\
\hline
\end{tabular}

Número Seqüencial do Registro: número seqüencial associado ao registro.

\section{REGISTRO TRAILLER}

\begin{tabular}{|c|c|c|c|c|c|}
\hline $\begin{array}{l}\text { POS. REG. } \\
\text { DE A }\end{array}$ & CAMPO/SIGNIFICADO & $\begin{array}{l}\text { QTDE } \\
\text { DIG. }\end{array}$ & CONTEÚDO & $\mathbf{A}$ & $\mathbf{N}$ \\
\hline 001 A 001 & $\begin{array}{l}\text { IDENTIFICAÇÃO DO } \\
\text { REGISTRO }\end{array}$ & 003 & $\begin{array}{l}\text { CONSTANTE “899” } \\
\text { OBRIGATÓRIO } \\
\end{array}$ & & $\mathrm{X}$ \\
\hline 004 A 009 & $\begin{array}{l}\text { QUANTIDADE DE REGISTROS } \\
\text { TIPO } 802\end{array}$ & 006 & $\begin{array}{l}\text { TOTAL DE REGISTROS DO } \\
\text { ARQUIVO TIPO } 802\end{array}$ & & $\mathrm{X}$ \\
\hline 010 A 015 & $\begin{array}{l}\text { QUANTIDADE DE REGISTROS } \\
\text { TIPO } 803\end{array}$ & 006 & $\begin{array}{l}\text { TOTAL DE REGISTROS DO } \\
\text { ARQUIVO TIPO } 803\end{array}$ & & $\mathrm{X}$ \\
\hline 016 A 021 & $\begin{array}{l}\text { QUANTIDADE DE REGISTROS } \\
\text { TIPO } 804\end{array}$ & 006 & $\begin{array}{l}\text { TOTAL DE REGISTROS DO } \\
\text { ARQUIVO TIPO } 804\end{array}$ & & $\mathrm{X}$ \\
\hline 022 A 027 & $\begin{array}{l}\text { QUANTIDADE DE REGISTROS } \\
\text { TIPO } 805\end{array}$ & 006 & $\begin{array}{l}\text { TOTAL DE REGISTROS DO } \\
\text { ARQUIVO TIPO } 805\end{array}$ & & $\mathrm{X}$ \\
\hline 028 A 033 & $\begin{array}{l}\text { QUANTIDADE DE REGISTROS } \\
\text { TIPO } 806\end{array}$ & 006 & $\begin{array}{l}\text { TOTAL DE REGISTROS DO } \\
\text { ARQUIVO TIPO } 806\end{array}$ & & $\mathrm{X}$ \\
\hline 034 A 039 & QUANTIDADE DE REGISTROS & 006 & $\begin{array}{l}\text { TOTAL DE REGISTROS DO } \\
\text { ARQUIVO INCLUINDO TODOS } \\
\text { OS HEADERS, TRANSAÇÕES E } \\
\text { O PRÓPRIO TRAILLER }\end{array}$ & & $X$ \\
\hline 040 A 045 & NÚMERO SEQUENCIAL & 006 & $\begin{array}{l}\text { SEQUENCIAL CRESCENTE NO } \\
\text { ARQUIVO }\end{array}$ & & $\mathrm{X}$ \\
\hline
\end{tabular}

Identificação do registro: número identificador do registro trailler do arquivo. Fixo '899'.

Quantidade de Registros Tipo 802: quantidade total de registros do tipo '802' existente no arquivo. 
Quantidade de Registros Tipo 803: quantidade total de registros do tipo '803' existente no arquivo.

Quantidade de Registros Tipo 804: quantidade total de registros do tipo '804' existente no arquivo.

Quantidade de Registros Tipo 805: quantidade total de registros do tipo '805' existente no arquivo.

Quantidade de Registros Tipo 806: quantidade total de registros do tipo '806' existente no arquivo.

Quantidade de Registros: quantidade total de registros existente no arquivo, incluindo header (cabeçalho), os registros '802' a '806' e o trailler.

Número seqüencial do registro: número seqüencial associado ao registro. 